\title{
WestVirginiaUniversity
}

THE RESEARCH REPOSITORY @ WVU

West Virginia Agricultural and Forestry Experiment

Davis College of Agriculture, Natural Resources

Station Bulletins

And Design

$1-1-1902$

\section{Commercial fertilizers : complete report for 1902}

\author{
J. H. Stewart
}

B. H. Hite

Follow this and additional works at: https://researchrepository.wvu.edu/ wv_agricultural_and_forestry_experiment_station_bulletins

\section{Digital Commons Citation}

Stewart, J. H. and Hite, B. H., "Commercial fertilizers : complete report for 1902" (1902). West Virginia Agricultural and Forestry Experiment Station Bulletins. 85.

https://researchrepository.wvu.edu/wv_agricultural_and_forestry_experiment_station_bulletins/85 @ WVU. It has been accepted for inclusion in West Virginia Agricultural and Forestry Experiment Station Bulletins by an authorized administrator of The Research Repository @WVU. For more information, please contact ian.harmon@mail.wvu.edu. 
Digitized by the Internet Archive in 2010 with funding from Lyrasis Members and Sloan Foundation 


\section{WEST VIRGINIA UNIVERSITY \\ AGRICULTURAL EXPERIMENT STATION, MORGANTOWN, W. VA.}

\section{Commercial Fertilizers.}

\section{COMPLETE REPORT FOR 1902.}

By J. H. STEWART and B. H. HITE.

[The Bulletins and Reports of this Station will be mailed free to any citizen of West Virginia upon written application. Address, Director of Agricultural Experiment Station. Morgantown, W. Va.] 
THE REGENTS OF THE WEST VIRGINIA UNIVERSITY

NAME OF REGENT.

P. O. ADDRESS.

Hon. W. J. W. Cowden, . . . . . . . . . . . . Wheelin:

Hon. C. M. BABв, ....................... Falls

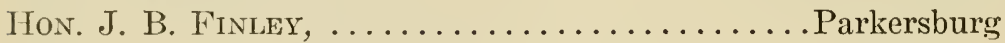

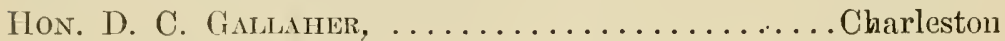

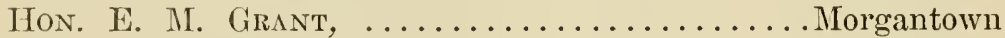

Hion. J. MI. IIALE, ...................... Princeton

Hon. C. E. HAwortir, . . . . . . . . . . . . . Huntington

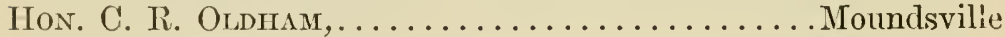

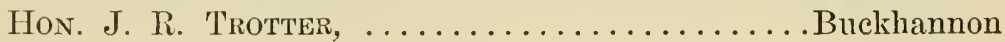

President of the Board of Regents,.......... W. J. W. Cowden President of the University,............. B. B. PuRintox

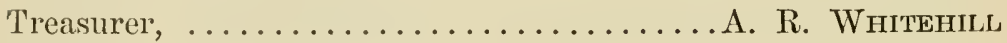
Auditor, ........................ J. White

\section{STATION STAFF.}

JAMES H. Stewhrt, A. M.,......... Director and Agriculturist Bert H. Hite, M. S.,...........Vice Director and Chemist S. W. Fletcher, PH. D.,................ Horticulturist IV. E. Rumsey, B. S. Agr.,........... Entomologist in Charge Hor $A$ Ce Atwood, M. S. Agr.,.........AssistantAgriculturist

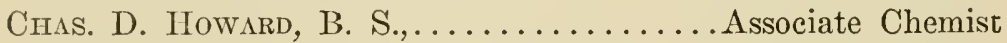

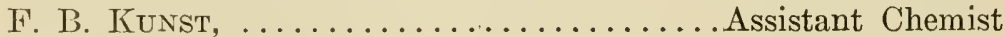

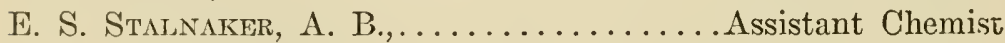
W. M. Morg $\Lambda$, B. S. A.,............ Assistant Horticulturist Grlbert M. John, ...............Assistant Horticulturist

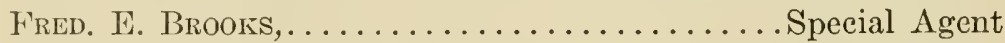

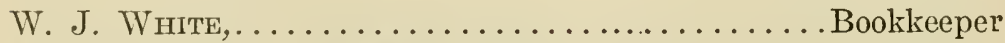

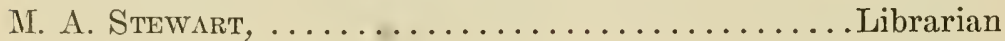

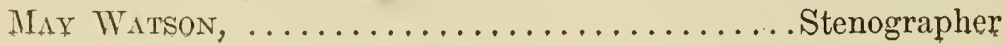




\section{Complete Report on Commercial Fertilizers for 1902.}

During the past year 294 brands of commercial fertilizers were registered for sale in this State. This greatly exceeds the number registered in any previous year. The reason for such an increase is not hard to find. It is due almost entirely to the removal of the $\$ 10.00$ to $\$ 30.00$ registration fee. Under the old law the manufacturers considered well the proposition to ineur the expense of registering a brand for which they did not alreacly have an established trade, and the case was even worse for firms beginning business in the State. By cutting down the registration fee to the nominal sum of $\$ 1.00$, all brands and all manufacturers are put on the same footing, and many brands heretofore unknown to the State are at the disposal of the farmers, who can the better meet the requirements of their soils and crops, while the competition of the firms heretofore excluded from the State has accomplished the usual result: fertilizers are sold on closer margins than ever before.

By putting all brands on the same footing the present law has encouraged the introduction of complete fertilizers and the higher class goods, or rather it has removed the reason for dealing so largely in fertilizers containing but one or two constituents, as shown by the following table, showing the proportion of the various classes of goods registered and sold during 1901 and 1902, in which connection it should be observed that the present law was in force for more than half of the year 1901: 


\begin{tabular}{|c|c|c|c|c|}
\hline \multirow[b]{2}{*}{ Classs. } & \multicolumn{2}{|c|}{1901.} & \multicolumn{2}{|c|}{1902.} \\
\hline & $\begin{array}{c}\text { Per c't Brands } \\
\text { Registered }\end{array}$ & $\mid \begin{array}{c}\text { Per c't } \\
\text { Tons Sold }\end{array}$ & $\begin{array}{l}\text { Per c't } \\
\text { Brands } \\
\text { Regist'd }\end{array}$ & $\begin{array}{l}\text { Per c’t } \\
\text { 'Tons } \\
\text { Sold } \\
\end{array}$ \\
\hline Complete fertilizers, . . . . . . i & 48 & 31 & 52 & 34 \\
\hline A.id Phosphates, .......... & 25 & 46 & 21 & 39 \\
\hline $\begin{array}{l}\text { Acid Phosphates, with } \\
\text { Potash, (bone and potash. }\end{array}$ & 18 & 18 & 18 & 23 \\
\hline $\begin{array}{l}\text { Bones, Dissolved Bones, and } \\
\text { miscellaneous, ........... }\end{array}$ & 9 & 5 & 9 & 4 \\
\hline
\end{tabular}

This report has to do with the fir'st full year's work under the New Fertilizer Law. The additional requirements of the new law greatly inerease the work of this department, but there is a good deal of satisfaction in knowing that every stroke of the work is necessary and valuable to all parties interested in fertilizers and that the law will be fully abreast of the times for many a year to come, for it provides the purchaser at the time the purchase is made, with all the information necessary to enable him to purchase and use any kind of a fertilizer to the very best advantage.

The distinctive feature of this new law is the provision in regard to the materials from which the various constituents of the fertilizers are derived. This has eome in for its full share of attention at the hands of manufacturers doing business in the State, and to their credit it should be said that with few exeeptions there has been little or no fault to find with it.

Some manufacturers have eontended that to compel them ro state under oath what they used in eompounding their fertilizers was an encroachment on their privilege to use what they pleas?, but the law does not say they shall use anything. It simply says that if they do use anything they shall state what they use, and use what they state, and that certainly ought to be fair enough. "They can use "rough on rats" if they care to do so, but if they use it they must say they use it and having said they use it, it must appear in the goods. This office is at a loss to understand 
why a manufacturer should shy at stating what he intends to use (if, as a matter of fact he intends to use it), unless he thinks he might otherwise palm the thing off for something better. In this matter there are just two points, and they boti fall weil within the only just ground for a fertilizer law or fertilizer coiltrol; to-wit: that the purchaser should have some way of judising as to the value of what he is purchasing. When one buys a cooking stove, or a rocking chair, or a hobby-horse, or almost any other thing that might be mentioned, his eyes are his marke, but this is not the case with fertilizers. No one can tell by looking at them whether they are what he wants; in fact, they may be just what he does not want. So, in the case of fertilizers it has been customary for a good while to require that statements made by manufacturers as to the composition of their fertilizers shall be in accord with the facts. The fairness of such requirements has long since ceased to be a matter of dispute, but this new law goes a step further and demands that the manufacturer shall disclose certain facts in regard to the composition of his fertilizers, whether he wishes to do so or not. He must state the materials used to furnish any constituent claimed and it is just here that the few objections referred to have come in.

It has been urged that such a requirement is smply an attempt to "meddle with the trade formulas, etc." of the manufacturer, but this office holds that about so much of such "meddling' is necessary for those who would purchase and use fertilizers intelligently. In this connection it should be observeci, however, that the great majority of the manufacturers doing business in the State do not seem to regard it as ineddling, while many of them seem rather pleased with such an opportunity in disclose the superiority of their goods, and to show that such matters upon which a fair estimate of their wares must so largely depend, are being so carefully considered in this State.

But the objection that has been most earnestly urged is of an altogether different character, and has to do with what a 
goodly number of manufaeturers seem to regard as their "privilege" to use any material that might be "convenient" to supply the requisite amount of any particular constituent, so long as they use only such materials as, in their judgment, might be termed "high-grade." They eontend that to state in advance what materials they will use is asking more than any manufaeturer could honestly state, as no one could tell so far in advanee, just what he might have to use; that he might state the materials he had on hand or was expecting to use, but that he might "run out" of these and be compelled to use something else, ete., etc. Now, if this office imagined for a moment that such statements define the status of the fertilizer business in this country, some paragraphs would follow that have not been included in this report, although such statements have been made by representatives of concerns doing no small part of the fertilizer business in this State.

Purehasers of Commercial Fertilizers certainly believe that the brand name stands for something. Manufacturers and agents have eertainly never orerworked themselves in an endeavor $t_{1}$ upset such a belief. Why give a thing a name if it possesses nothing to distinguish it from anything else? In finding fault with the law (as above mentioned) for" "meddling with tracke seerets," it is implied that the various brands posses characteristies of value, but when the same manufacturers insist upon the "privilege" of using anything they may find "convenient" in compounding such "brands," it would seem that the only "trade secret" likely to suffer is the deception of such a practice. The "trade seerets"' really worth "meddling with" are usually found in big letters on the bags.

One other objection often urged against the requirement in question is, that it ean do no one any good, as the farmers do not understand the differences or "refinementa" in composition it is ealculated to diselose. It must be admitted that there are yet many farmers who do not understand such matters, but it is 
quite probable that the number in this State is by no means as large as some have supposed. This office has never missed an opportunity in its correspondence, bulletins or addresses at farmers' meetings, to awaken an interest in these subjects, bolieving as it has and does that the greatest source of loss to both makers and users of fertilizers is the failure on the part of both to appreciate the importance of just such "refinements." The manufacturer who wants to stay in the business wants his fertilizers to be used to the best possible advantage, and how on earth can this be done if the user is to ignore or be kept in ignoranus of the information without whic hthe fertilizer may even be worse than no fertilizer at all. This office claims that without the irformation found on the tags required by the present law, no one can purchase or use a fertilizer to the best advantage. Of course a purchaser might be able to obtain the same information some other way, but even then he would be none the worse off for having it before him at the time of the purchase, in the form of a sworn statement. The purchaser might have learned by actual trial that a particular brand was what he needed for a particular crop, on a particular soil, for a particular kind of a season, but suppose that when he ordered the same brand the next year the manufacturer had "run out" of the materials used the year before and so had found it "convenient" to substitute something else. The law requires that as often as the composition of a brand is changed the manufacturer shall make a corresponding change in his affidavit, so that the purchaser may be advised of. the change by the tags at the time the purchase is made.

It is to be observed that the manufacturer does not have to state what he intends to use so very long in advance; as a matter of fact the majority of his statements have to do with fertilizers that have been made and drying for weeks or even months. The manufacturer can file his affidavit any time in the year he pleases so he really does not need to make any statements in advance. The thing to which he really objects, is being compelled to keep his brands constant, or admit that they are not constant. In 
other words, the law either deprives him of the "privilege" of using anything that happens to be "eonvenient" in eompounding a "brand" or compels him to admit that the brand narre means nothing at all.

It should be needless to add that the above remarks apply only to those manufaeturers who have claimed that the requirement in question is a hardship, and whose agents (more partielllarly their general agents), have been rumning about through the State trying to break the eonfidenee of purehasers in what is unquestionably the best fertilizer law in the United States. They talk about the awful tag tax and the ineonvenience and $2 x$. pense of attaching the tags, ete. Now, this little matter of manufacturers making a fuss about maintaining a fertilizer inspection (whieh, as they always elaim, only diseloses the great superiority of their goods), is as old as the oldest fertilizer law and has been worked just as long as just as often as the laws have stood in the way of their "privilege" to eheat the purehaser. If any one will but take the time to look into the history of fertili\%er legislation, he will find that a law that is really calculated to protect the purehaser invari: bly carries with it an odious and burdensom: tag (or other) tax, and many additional ineonvenienees and expenses, although the manufacturer making such objections always elaims to be most heartily in favor of the inspection, if orry it eould be done in any other may than the one adopted. As for the inconvenience and expense of attaching tags, it ean oniy in? said that it doubtless is inconrenient and expensive to attach a sworn statement that would diselose a deeeption which but for the tag might be worked at a profit, also at the expense of the farmers, and of the manufaeturers who eannot see their wy clear to profit by sueh deceptions.

Such manufacturers in their eorrespondenee and their generals agents, in their preaching, are always eareful to state very adroitly that the matter of expense is nothing to them, as the 
farmer pays it in the end, but since when did they awaken to such a lively interest in the farmer? It has not been so long but. that some of us can remember when some of these same firms sold fertilizers worth $\$ 11.00$ for $\$ 20.00$ a ton and their agents not being satisfied with this, diluted the stuff with more than half its weight of coal ashes, or whatever happened to be "convenient," but those were the good old days when there was no fertilizer law in this State, and consequently no reason for the excuses which have so little to do with the real reasons for finding fault with the present law. Isn't it just a little strange that such a lively interest in the agents and farmers should be coincident with the first year's enforcement of the New Fertilizer Law in this State. The facts in the case are simply as follows: this State was slow in enacting a fertilizer law and for a long time was a "convenient" dumping ground for anything that could not be dumped elsewhere. When at last it did pass a fertilizer law it adopted what were regarded as the best features of the laws then in existence in other States. These laws recognized only the amount of the various constituents claimed, regardless of their quality and so did the old law in this State. Any law that has to do with the "privileges" of a certain class of manufacturers is sure to come in for its share of objections, and even our old law was no exception. But in time manufacturers of the class referred to discovered that in a law devoted to the amount of the various constituents, regardless of the quality, there was an opportunity that measured right up to their standard, in that they could use any sort of cheap materials to provide the requisite amount of the various constituents and be reported "up t', guarantee" right along with the manufacturers who had too much pride in their business and respect for the confidence of their purchasers to use anything but high grade materials. So the manufacturers and general agents in question became ardeut advocates of the old law, although the burdensome tag tax, resistration fees, ete., cost them more than it does now, and no one heard from them of the inconvenience or expense of attaching a 
tag that placed the same value on inferior materials that it did on the most expensive materials. Those now in cliarge of this office took the first opportunity to secure the enactment of a law that was not exactly in tune with the opportunities referred to and the fault that has been found with it is no surprise; indeel, it is the best reeommendation that could possibly eome from such sources.

Thousands of copies of the old law and the new one have been distributed among the farmers of this State, so it should be no very difficult matter to establish the fact that there are but three points in which there is any difference between the two. The New Law requires: 1 - that the agent shall notify the Direetor of the Station as to the kind, amount, place and approximate time of delivery of fertilizers shipped into the State. The objeet of this requirement is obvious, and there have been no objections to it.

2-The necessary revenues for maintaining the fertilizer inspeetion are put on a tonnage basis, absolutely fair to all concerned, and which, as a matter of fact, requires less of the faultfinders than of the manufacturers whose business integrity has secured for them a much larger part of the trade in this State, but who, by the way, are having no fault to find.

3-The only other ehange in the original statute may be summed up in nine words, to-wit: "and the materials from which said constituents are derived," and this is the particular place where the shoe pinches. This is the real reason for all the complaints to date. A certain elass of manufacturers have so long been profiting by the sort of deeeptions these nine words are sc well ealeulated to prevent that they have come to regard them as but another one of their "privileges"; henee the howl. This office is thoroughly advised and intends to keep advised, as to the firms who have so suddenly become so anxious to deliver the agents and farmers of this State from the burdensome "tag tax" and the inconvenience and expense of attaching tags, etc. In 
view of the hundreds of thousands of dollars that go out of this State to the manufacturers of commercial fertilizers every year, somebody ought to know who the manufacturers are who object to contributing their share to the inspection work in this State, no matter what may be their real reason for such objections. In the cases above referred to (and as is usually the case) the objection is but the expression of the unwillingness to discontinte the sort of practices but for which fertilizer laws would be unnecessary.

It should be needless to add that for the great majority of manufacturers, such a requirement would be unnecessary, so far as it has to do with uniformity of composition. They have too much faith in the formulas that have stood the test of so many years and too much pride in their business to quibble abont the "privilege" ("if convenient") of selling out so cheaply the confidence of those who have learned to appreciate the merits of such formulas. For such manufacturers the law has no hardships. With them a brand means something, and they could file their affidavit for ten years in the future. Indeed, for such manufacturers the law has a decided advantage, in that it enables the purchaser to readily pick out the brands that really stand for something. There is, of course, the other and greatest of all advantages in that the farmer is provided with all necessary information to enable him to make the very best possible use of the fertilizer. The fact that many farmers do not yet understand the reasons for using a constituent in one form rather than in another, is to be regretted, but it might be added that there is no lack of manufacturers who don't seem to be very much better informed than the farmers. Nor does the ignorance in question end here. It has not been more than a thousand years since a Professional Agriculturalist in a State institution, in publishing the results of certain "investigations" involving actual fieid tests with fertilizers", stated that a "commercial fertilizzer costing" so much per bag gave only such and such results, "while "a home mixed fertilizer" gave almost as good results as farmyard 
manure, without even mentioning the kind or amount of any constituent used, much less the materials used as the sources of the constituents. Ile didn't even mention the size of the "bag." Me did say that the freight on it was about su much, without saying how far it had been shipped. This is, of course, an extreme case, and possibly the worst to date, but the difference in altogether too many eases is one of degree, rather than of kind. One can take the reports of only too many "actual field tests with fertilizers," and prove almost anything he pleases. There is a reason for such confusion, and there can be little doubt but that altogether too mueh of it could be easily traced to this same lack of appreciation of the materials from which the various added constituents were derived. Too many such investigations have attributed the whole results to the differences in the amount of phosphoric acid, nitrogen or potash used, completely ignoring the effeet of the materials with which these eonstituents are necessarily united or associated, the effect of which is just as sure to follow and possibly be responsible for the greater part of the "results." So, then, while it must be admitted that the farmers do not appreciate to the extent that might be desired the importanee of using a eonstituent in one form rather than another, it must also be admitted that such lack of appreciation is not limited to them, but is well represented among manufaeturers ancl others, who would naturally clain to be much better informerl. This office eould think of no better way of enforeing such an appreciation than to have the manufaeturers state the sources of the constituents elaimed, and keep such statements eontinually before the purchasers.

Bulletin 80, of this Station, diseusses at some length the effeet of the various materials used as sonrees of the various eonstituents of commereial fertilizers. Many farmers elaim that it has been of much assistance to them. Differences in the "form" of a constituent are very largely a matter of the otiner materuals with which the eonstituent in question is necessarily united or associated. It is these other materials and their effeets that are 
too often overlooked. The fact that one has phosphoric acid in mind when he applies phosphate of lime to the soil, does not prevent the lime from exerting its full effect and with just as much certainty as if it had been the "constituent" for which the applieation was made. The falling paragraphs may be of service in calling attention to these various materials with the phosphoric acid, potash and nitrogen are associated in their various forms.

Bones are used to furnish phosphoric acid and nitrogen, but they do not consist entirely of these materials. They contain organic matter, lime, magnesia, etc., but as these other constituents can do no harm and may do good, bones are and have long been recognized as a perfectly safe and valuable source of phosproic acid and nitrogen. Like most other organic manures, bones are rather slow in their action. They must first decompose and such decompositions are always more or less a matter of circumstances, including the character of the soil, season, etc. Decomposition is hastened by steaming the bones, thus removing the useless fats and greases which would otherwise exclude the necessary moisture and air. The finer they are ground the more surface will be exposed to the action of soil, water and air, and the more quickly they will decompose. For permanent pasrures and slowgrowing crops there is no better source of phosphoric acid and nitrogen. It should be observed, however, that before plants can use the nitrogen in bones or any other organic materials, it must be converted into nitric acid or some compound of nitric acid, by a process or series of decompositions known as nitrification, which is accomplished in the soil by certain minute organisms known as bacteria, and that these are rather particular as to the conditions under which they will work; e. $g$. they will not work in a sour soil, and the best results need not be expected from an appliaation of bones or any other organic nitrogenous material to an acid soil. The remedy for an acid soil is lime. (See Bulletin No. 80).

Dissolved Bones. In order to make the phosphorie acid and 
nitrogen in bones immediately arailable, bones are treated (dissolved), in sulphuric acid. This is all very mell for the phosphoric acid and nitrogen, but how about the other constituents, (lime, magnesia, etc.), of the bones. Well, the line and magnesia are converted into sulphates. The two materials are very much alike, and everyone knows that the sulphate of lime (gypsum)) is not likely to do any harm; indeed, it is very likely to prove a valuable addition to the soil. So. when phosphoric acid and nitrogen are added to the soil, in the form of bones or dissolved bones, the other materials added require no attention, as they can do no harm and will probably do good. For slow-growing crops no one is likely to make a mistake in applying phosphoric acid and nitrogen in the form of ground bone. For quick-growing crops no one is likely to make a mistake in applying these constituents in the form of dissolved bones.

Dissolved Phosphate Rock is sometimes ealled "Dissolved Bone" or "Dissolved Bone Phosphate." Such terms are, of course, misleading, but they are not necessarily intended to deceive, as they are well reeognized by the trade. It is quite possible that phosphate roek is but the remains of the skeletons of prehistoric animals. It consists for the most part of the mineral constituents of bones, necessarily mixed with other earthly materials. Of course all nitrogen and organic matter worth mentioning has long since disappeared. The earthy miterials with which the original bone constituents have become contaminated need no special attention, as they are found in abundance in all good soils. They simply dilute the phosphate of lime and make it necessary to use more sulphuric acid to convert the phosphate into available form, but in the manufacture of soluble phosphates (acid phosphates) from phosphate rock, no objectionable products are formed, certainly not if the process is properly carried out, as it almost invariably is at present. It is also to be observed that while untreated ground bone decomposes much more quickly than the untreated ground phosphate rock, such differ- 
ence does not obtain for the bone and rock when treated with the sulphuric acid, for the phosphate of lime in the bone and the phosphate of lime in the rock are both converted into the same soluble, or "available" phosphate of lime, and that so far as the soluble phosphoric is concerned there is no advantage in using bones to make acid phosphates. It is sometimes claimed that the acid in the acid phosphates will parch or otherwise injure the soil, while real dissolved bones, being just simply bones dissolved, can have no such effect and so are much to be preferred, but as has just been stated, both are made by the same process. 'There is no more "acid" in the acid phosphate made from rocis than in that made from bones. The soluble phosphate produced in each case is one and the same thing always, and requires exactly the same amount of lime for its fixation in the soil, which amount is less than the actual phosphoric acid added, while a normal soil will contain at least 3,000 lbs. of lime in the surface foot per acre. Even the small quantity of lime required to effect the fixation of the soluble phosphate is not lost to the soil, but is either used by the plant or set free when the phosphoric acid is used. There is absolutely no reason why acid phosphates should tend to parch or sour or in any way injure the soil, indeed their action is in just the opposite direction. As a source of available phosphoric acid there is nothing better than a plain acid phosphate made from the phosphate rock.

Bone Tankage is the material remaining in the large tanks used in the slaughtering establishments for boiling cattle heads, hoofs, clippings and animal refuse matter generally. A number of grades are found on the market, varying in phosphoric acid from 10 per cent. to 20 per cent. and in nitrogen from 4 per cent. to 9 per cent. Even these wide limits will not include all the tankage on the market. The composition of some varieties approaches that of bone, while a material known as "concentrated tankage" and prepared by evaporating the fluids obtained in the extraction processes contains very little phosphoric acid, but may 
contain as much as 12 per cent. of nitrogen in quiekly available form. What was said in regard to ground bone will suffice for: erushed tankage, if it is borne in mind that the latter contains more organic matter and must have favorable conditions for the best results. Contrary to popular notions, it is the tankage anı! other materials rich in organic matter that contribute most to an acid condition of the soil and which are likely to give the most indifferent results when such a condition exists. Of course there is not so much as a ghost of an exeuse for allowing a soil to get in such a condition, and yet this indisputable tendency of the materials in question must not be overlooked.

In order to make the phosphoric aeid and nitrogen more quickly available (and with greater certainty), erushed tankage, like ground bone, is often treated with sulphuric aeid. The produet is known as dissolved tankage, but has so mueh in eommon with dissolved bones that further eomment here is unnecessary. The eoneentrated tankage referred to decomposes so quickly that such treatment is unnecessary. The same is true of dried blood, meat meal guano, azotine and eertain other highly nitrogenous animal produets.

Speaking of highly nitrogenous animal products naturaliy recalls hair, hoof-meal, bone-meal and leather-meal, which may contain as much as 15 per cent. of nitrogen, but which decompose so slowly that they are of little value as a manure. They are to be recommended only to those who believe in feeding the soil, rather than the erop, or to those who attach so much importance to the "lasting effects" in regard to which one always hears so much, for these materials have lasting properties to give awav; indeed, they are likely to last so long that no one will ever know just when they did become available. Such materials ean bo used to greatly increase the nitrogen eontent of a fertilizer (withont adding anything to its value) in States where the fertilizer laws recognize only the amount of the various constituents, ignoring "the materials from which said constituents are derived." 
Some States have enacted laws forbidding the use of such materials, but the law-makers of this State did not think best to incorporate such a requirement and they were right. Those who believe in lasting effects pay taxes. They also pay the fiddler for their belief. They ought not to be deprived, by law, of such an opportunity to confirm their faith, at least so long as anyone is willing to admit that he has such materials for sale and sells what he claims to sell.

In dealing with animal or vegetable products, (organic miterials), one point is always in order, and that is, that plants were not designed to feed on vegetable or animal matter and that a constituent in such form is not the more palatable to them. On the contrary, they cannot use any constituent of any vegetable or animal tissue until it has been completely decomposed or broken down into the same original mineral constituents used by the preceeding plant, and that such decompositions (in the soil) are always more or less a matter of conditions ( soil, season, ete.), which may or may not always exist just at the right time. In other words, there is always about so much uncertainzy attending the use of any constituent in the form of an untreated organie material. The more quickly decomposable and consequently more quickly available materials may usually be relied upon, and those requiring more time may often be used to decided advantage on slow-growing erops, while if such materials are properly selected for a particular crop, on a particular soil, and the season is also favorable, there may even be an advantage in that, the decompositions taking place just right, the crop will be ferl more uniformly than if the constituents were immediate available. However, the fact must not be overlooked thai in order to use such materials to best advantage the conditions in question must obtain.

Sulphate of Ammonia is an important source of nitrogen. It is immediately soluble and in a normal soil, under anything like fair conditions, is quickly available. Many believe a constituent 
is immediately available because it is immediately soluble (in water), e. $g$. the availability of the soluble phosphate of lime, which, as a matter of fact, is quickly converted by the soil int:s an insoluble form, which owes its availability to the minuteness of its particles and the uniformity of their distribution among the soil particles. Sulphate of ammonia is an example of a material that is immediately soluble, not necessarily converted by the soil into an insoluble form and yet not immediately available. Of course plants can use some nitrogen in the form of ammonia, but this is not the rule. Plants want their nitrogen in the form of nitric acid or some compound of nitric acid. The transformation from ammonia to nitric acid in the soil involves but a few steps; which, under favorable conditions are quickly accomplished. It is for this reason that sulphate of ammonia is one of the most reliable sources of nitrogen, but the few steps must be taken and the conditions must obtain. The process involved is the one already referred to,--nitrification, and the conditions do not obtam in a soil that is dry or sour or water-logged or gorged with organic matter. There are well established cases where sulphate of ammonia, on acid soils gave worse results than no fertilizer at all. Again it is to be observed that in a state with limestone in every other hillside, in some cases a hundred feet thick, there is no excuse for an acid soil, and yet so long as so many agriculturalists, practical and professional are stuffed full of the notion that the soil must be stuffed full of organic matter which, on decomposing may produce an acid condition, it may be just as well to call attention to the materials which tend to aggravate such a condition. Under anything like fair conditions sulphate of ammonia is a very quick acting and valuable source of nitrogen; indeed, it stands next to

Nitrate of Soda.. The great majority of the materials used as fertilizers are converted by the soil into other forms before being used by plants. As a matter of fact such added materials are sooner or later converted into just such forms as plants would 
use in a soil to which no such additions had been made. This does not support to any very considerable extent the notion that commericial fertilizers are "artificial" or "unnatural," but it is nevertheless a fact, and a very fortunate one for modern agriculture. Conspicuous among the materials that need no such transformations, but which can be used by plants in the form in which they are applied as a fertilizer is nitrate of soda. It is immediately soluble and immediately available. The only danger is in loss by leeching, for the soil can not convert it inio an insoluble form, and unless it is used at once it is liable to be lost. It should be applied when it is needed. As it does not have to undergo any decompositions in the soil before becoming vailable it is more certain in its action than the organic materials mentioned. It is simply a compound of nitric acid and soda and so contains nothing that can possibly be injurious; in fact, the action of the soda is just the reverse of that of other materials with which the nitrogen in most other forms is associated.

The Potash in commercial fertilizers is obtained almost entirely from the famous Stassfurt deposits.

The potash of the Stassfurt salts exists in two forms, the chloride, which is probably better known as muriate, and the sulphate. Both are readily available and securely fixed in the soil. There is a difference, however, in the diffusibility of the two; forms, the chloride having the advantage in this respect, for experience shows that it will distribute itself through a larger volume of soil before becoming fixed.

There is another difierence between these two forms that demands more careful attention, and this has to do with their effect on certain crops. Sulphates, as a rule, are a valuable addition to the soil, and the sulphate of potash may be used indiscriminately on any and all crops; but the same is not true of the chloride of potash, for while this may be depended upon to produce a corresponding increase in the yields, it is likely to injure this quality of certain crops, and these, unfortunately, are among the 
crops requiring potash in the largest quantity. The chloride of potash injures the burning qualities of tobacco, and as the value of tobaceo depends so largely upon this quality, the chloride of potash should never be used on this crop. The chloride of potash will give to potatoes a waxy consisteney, and increase the impurities and lower the suger content of sugar beets; so it is the sul. phate of potash that should be used on these erops. On the great majority of crops, as grains and grasses, it makes little or no ditference which form is used, and the chloride being the cheaper may often be used to advantage; in fact, there are eases in which it even gives better results than the sulphate, $e . g$. on hemp and certain other fibre plants, where it tends to lengthen and toughen the fibre.

When the chloride of potash is applied to the soil, the potash becomes fixed, the ehlorine with which the potash was combined, being left to combine with some other constituent of the soil, usually lime, to form chloride of lime. This chloride of lime, or calcium chloride, is very injurious to the rootlets of young plants, but it is an extremely soluble material, and the soil has no power to hold it, so it is quickly leeched out in the drainage water. This suggests a method of using the chloride of potash that would avoid much of the injurious effects; apply it as long as possible before the crop is planted. If applied in the fall, the winter rains may be depended upon to either wash out the ehlorides or earry them so far into the lower layers of the soil that they wiil be out of the reach of young plants beginning their growtl in the spring.

It should be distinetly understood that the differenees abo:s referred to are not due to any difference in the actual potasis (which is one and the same thing in both forms, and the worl? over) but to the materials with which the potash is associated. When the potash becomes fixed in the soil it parts company with these materials to unite with the silicates, etc., and in uniting with these the various forms of potash applied to the soil as fer- 
tilizers are converted into forms very similar indeed to the quiskly available potash already in the soil. A part of the potasin found on the market is in the form of chloride of potash, which is the cheapest form of potash arailable at the present time. On certain crops chlorides are injurious and the above is to show how the injurious effect of chlorides (not potash) may be avoideci.

Kainit is doubtless the best known of the crude Stassfurt salts. It contains about 12.5 per cent. of actual potash, practically all of which is in the form of sulphate. It also contains large quantities of chloride of soda (common salt) and chloride and sulphate of magnesia, so, notwithstanding the fact that the potash is in the form of sulphate, the large excess of chlorides with which it is associated, causes kainit to act very much like the chloride of potash, and the same precautions should be observed in using it.

Sylvinit is another crude product, similar to kainit, in that it contains large quantities of common salt, chloride of magnesia, etc. The actual potash, which is in the form of chloride and sulphate, will average about 16 per cent. In this country it has not been used to the same extent as kainit.

The crude potash salts, such as kainit, sylvinit, manure salts, etc., contain not only chlorides (such as chloride of potash, chloride of soda or common salt) but they also contain considerable quantities of magnesia. Recent investigations go to show that too much magnesia in a soil is very undesirable, as it may, if present in large excess, reduce a soil to the verge of sterility, even when the soil is normal in all other respects. From the inrestigations referred to it appears that good results need not be expected if the soil contains more magnesia than lime. Crude potash salts not only remore some of the lime, but add to the magnesia. On the other hand, too large an excess of lime is not desirable, and in such a case the crude salts might be used to a:lvantage. Farmers must study their soils.

Iuriate of Potash.. Of the manufactured products, muriate 
(chloride) of potash is the most generally used. Several grades of this material are to be found on the market, some of them rumning as high as 93 per cent. chloride of potash. The most popular grade in the comntry is about 80 per cent. pure, and contains about 50 per cent. potash.

It will be observed that there are just about four times as much actual potash in this high grade muriate as in kainit, and notwithstanding the marked difference in price, a little figuring (including freight rates, etc.), will show that the muriate is much the cheaper form. It is also to be observed that in using the high grade muriate (although this is almost pure chloride of potash) a smaller amount of chlorides will be applied to the soil than if the same amount of potash in the form of kainit be used. The muriate is the cheapest form of potash on the market to-day, and for the great majority of crops (and with the simple precautions already mentioned) it is for most purposes all that could be asked in the way of a potash fertilizer.

High Grade Sulphate of Potash is usually sold on a purity basis of 98 per cent., or an equivalent of 53 per cent. actual potash. It is used extensively in the manufacture of commercial fertilizers, and is undoubtedly the best form of potash for agricultural purposes obtainable at the present time. It is to be preferred to the muriate because it ean be used on any crop at any time. It is one of the most expensive forms of potash, and yet, the prices often paid for kainit would purchase an equivalent amount of potash in the form of high grade sulphate.

The Stassfurt potash salts are quite eapable of meeting every demand of the soil for potash, and when they are applied (o!)serving the precautions above mentioned) to a soil deficient in potash and fail to bring reasonable returns, the trouble is due to a lack of lime or to some other abnormal condition of the soil, not to the potash salts.

The following table will be of service in showing the form in which the potash exists in the various potash salts, the amount of 
COMMERCIAL FERTILIZERS-REPORT FOR 1902.

chlorine and other materials present and the amount of chlorin:s that should be found for one per cent. of potash in the various forms claimed: 
WEST VIRGINIA EXPERIMENT STATION.

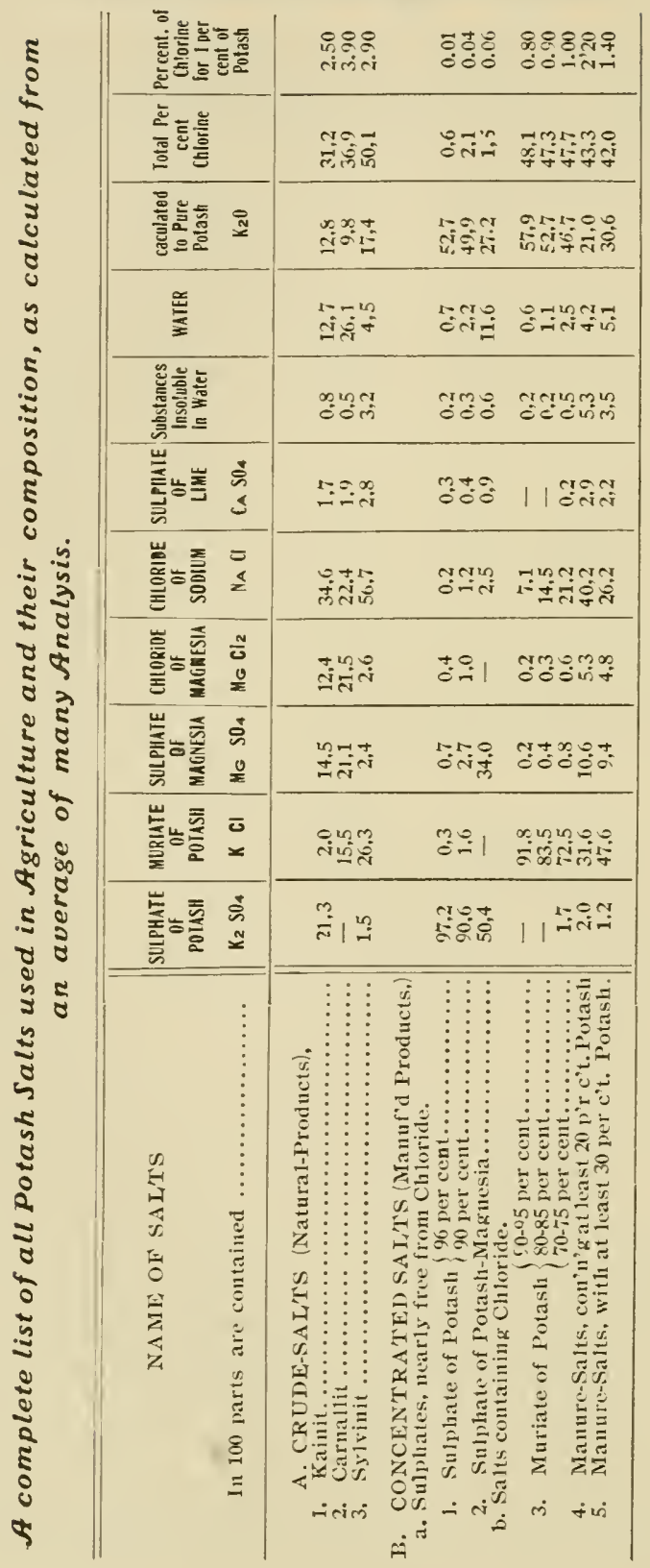


In the following report of the inspection and analysis of fertilizers found on sale in the State, a number of new terms appear among those already familiar to readers of the reports of this office, while one item, the valuation, has been omitted. The usuai statements in regard to the soluble, reverted, total and available phosphoric acid guaranteed and found are presented, not in the form of a table, as heretofore, but in much more readable form. These statements include all the information necessary to enable one to purchase and use the various forms of phosphoric acid intelligently.

As often as nitrogen is claimed an availability test is reported. It should be understood that these figures are relative, that is to say, if the nitrogen in one fertilizer gives an availability test of 80 , while another gives a test of 40 , it is safe to assume that on a normal soil, under fair conditions, twice as much of the nitrogen in the first case will be quickly avallable as in the last. As relative figures they are not very far wrong; as absolute figures, it can only be said that they are obtained by the methods of the American Association of Official Agricultural Chemists, and so are undoubtedly as nearly in accord with actual field tests as is possible at the present state of the sciences involved. There are many opportunities for these figures to he misleading within certain limits, unless properly understood; for example, "dried blood" might be claimed and dried blood might be used, but it might be carelessly dried, dried too much, or at too high a temperature. It would give too low a test in the labocatory and in the field. Again, it should be observed that these tests are based upon what might be called an average erop on ar average soil during an average season. The dried blood, for example, might be the very best obtainable, but if used on an acid soil or a soil that did not need nitrogen, or for a quick-growing crop, when the season was unfavorable to nitrification at the time the crop needed its nitrogen, or favorable later when it could only prolong the period of growth favoring stalks and stems at the expense of the grain or fruit, or the promotion of 
fungious diseases, the tests will not be in accord with the figures given. A number of brands registered this year claim nitrogen in the form of "Bone 'Tankage," which was undoubtedly uset. The availability tests, however, are low, because the material was unusually coarse. Here, again, the field tests will be in accord with the laboratory tests. Examples might be multiplied almost indefinitely, but suffice it to say that these availability tests is carried out by this office represent the best efforts of those most competent to deal with these problems and the results as stated, are a resonably reliable and valuable guide in selecting and applying the various nitrogenous materials used in fertilizers.

Examinations in the laboratories here are not limited to the availability tests reported, but include mieroscopical and any other tests calculated to disclose whether or not the nitrogen (or any other constituent) is derived from the materials stated. The results of such findings are given in the remarks which in th: case of nitrogen it is gratifying to note are conspicuous on account of their absence, and the nitrogenous materials used in the fertilizers as sold in the State this year, with few exceptions, make a good showing. When manufacturers urderstand that they will get full credit for the materials actually used there is some incentive to use the very best they can for the prices they expect to charge; indeed, if there ever is a time when a manufacturer would be excusable for using less dried blood and more hoof-meal, it would be when he is compelled to do business with a statute that recognizes no difference between such materials but "values" them both alike. The fact that manufacturers even under such circumstances so infrequently resort to such practices is an argument for business integrity and business pride that cannot be discounted by any other business on earth.

In the case of Potash, the matter of availability is practicaily one of minor importance, as almost without exception the materials claimed and used are immediately available. The matter of greatest importance is the chlorides, with which so many potash salts are associated. It is for this reason that the results 
of the examination as to the materials from which the potash is derived are stated in terms of chlorine. The amount of chlorine contained in the rarious potash salts used in commercial fertilizers may be found in the table (under potash), already given.

Valuations are not required by the New Law and so are not found in the report. There are a number of good reasons for this. A valuation may be right at the time it is published, but long be. fore another report can appear prices may change. It is the only figure in a fertilizer report that is sure to be unfair to some one some time. Of course a valuation may only claim to be relative, but even in this case local conditions may make it advisable for manufacturers or dealers to cut prices on certain classes of goods and so it goes. There was a time in this, as in every other State, when the figures with a dollar mark in front of them meant more to many purchasers than any other figures on the tags, but that time is passed. And after all and even if the valuations could be absolutely correct at all times, why should not a farmer keep himself posted as to prices current of the materials he may need for fertilizers, just as he does in the case of corn, wheat, oats, hay and every other commodity in which he is interested. This is the only solution for the valuation problem, and it leaves the fertilizer laws to begin and end, as they should, with providing just such and only such information as in the nuiure of the ca:se cannot otherwise be obtained. The prices of materials used in the manufacture of commercial fertilizers as given in the following list may be relied upon. They are taken from the Oil, Paint and Drug Reporter, March 9th, 1903, and are the last quotations obtainable before this report goes to the printer. It should be needless to add that they are for large lots. Smaller purchasers would have to pay higher prices and might not be able to obtain șome materials at any price. 


\section{AMIMONIATES.}

Sulphate of Ammonia, ........ Cwt. $3.10 @ 3.125$

Nitrate of Soda,............ Cwt. $.1 .95 @ 1.975$

Blood, dried, red,............ Unit $2.65 @ 2.70$

Concentrated Tankage, ....... Ton, $15.00 @ 16.00$

Fish, Guano, dried,........... Ton, $27.00 @ 28.00$

Fish, acidulated,............Ton,

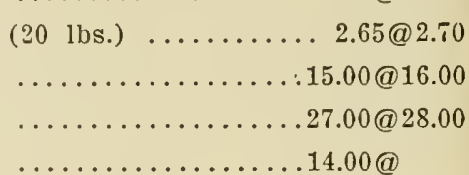

\section{PIIOSPHATES.}

Phosphate Rock, F. O. B.,

Charleston, ............. Ton, $5.00 @ 7.00$

Phosphate Rock, F.O.B., Tenn...Ton, $.3 .60 @ 3.75$ Acid Phosphate ... Unit, $.60 @ .675$

Bones, rough, .............. Ton, $.16 .50 @ 17.50$

Bones, ground, ............. Ton, $.20 .00 @ 21.00$

Bone Meal, $18.50 @ 24.00$

Bone Black, refuse, ..........Ton, $.18 .00 @ 19.00$

\section{POTASHES.}

Double Manure Salt,48@53 per ctCwt. $1.12 @ 1.15$

Sulphate of Potash, 90@98 pr ct.Cwt. $2.11 @ 2.18$

Muriate of Potash,.............. $1.83 @ 1.95$

Kainit, $2 \overline{5}$ per ct. Sulphate,..... Ton, $9.30 @ 9.50$ Silvinit,. $35 @ 37$ per ct.,......... Unit,

To the above prices of materials must be added the eost of manufacturing, the profit to the manufaeturer, the freight and a eommission to the agent. At every turn there are many matters to be taken into account. Many of these, however, are local and so are best known to the purchaser, e. $g$. the freight to his particular shipping point, or the amount of fertilizers sold there. If it is a good farming section, with a heavy fertilizer trade the agent can place orders with his companies that will secure lower prices and the farmers will get fertiiizers cheaper than in a section with an indifferent fertilizer trade. There are many other points that 
might be mentioned or that will suggest themselves. There is, however, one that should not be overlooked, and that is the possible losses from bad sales, against which the agent must fortify himself. Sometimes it is the agent, sometimes the manufacturex who loses (according to the nature of the contract), but in the long run it is the farmers of that seetion and unfortunately the farmers who pay their debts; and they may pay good interest on such losses for some years to come. The average fertilizer agent. in West Virginia can ill afford to lose the price of more than two or three carloads of fertilizers in a years, so it does not take more than about so many bad sales to put him out of the business. A new man takes his place; possibly a half dozen new men, none of them so well known to the manufacturers, who proceed to fortify themselves, and so it goes. Representatives of the various fertilizer companies are always quick enough to say that West Virginians are in the front rank when it comes to paying their debts, and this is doubtless true. The subject is simply mentioned as one of the many local faetors affecting the retail price. It is probably safe to say that the majority of manufacturers would be only too glad to aceept as their profit on most of their brands the difference between the highest and lowest price which local conditions (freight, amount of goods sold, etc.), make it necessary to charge the farmers in different sections. The farmer is better informed on loeal conditions than anyone else. It but remains for him to keep himself posted on the prices of fertilizer materials, ete., and whenever he demands it such quotations will come regularly to his fireside in every paper that dare claim to be "agricultural." This is the only solution to the "valuation" problem.

The following schedules of prices were used during the year 1902, in the States named: 
NEW ENGLAND STATES AND NEW JERSEY.

\begin{tabular}{|c|c|c|c|}
\hline & Cents & yer to & 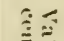 \\
\hline & 1901 & 1902 & 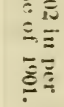 \\
\hline 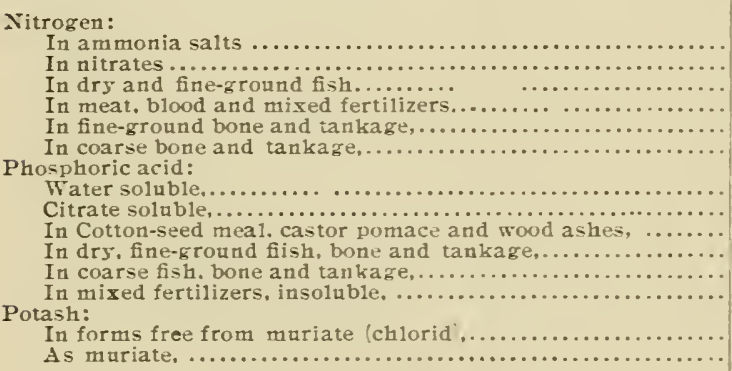 & $\begin{array}{l}161 / 2 \\
14 \\
16 \\
16 \\
16 \\
12 \\
5 \\
41 / 2 \\
4 \\
4 \\
3 \\
2 \\
5 \\
41 / 4\end{array}$ & $\begin{array}{l}151 / 2 \\
14 \\
16^{1 / 2} \\
16^{1 / 2} \\
16^{1 / 2} \\
12 \\
5 \\
4^{1 / 2} \\
4 \\
4 \\
3 \\
2 \\
5 \\
4^{1 / 2}\end{array}$ & $\begin{array}{l}100 \\
100 \\
100.1 \\
100 \\
100 \\
100 \\
100 \\
100 \\
100 \\
100 \\
108 \\
100 \\
100 \\
100\end{array}$ \\
\hline
\end{tabular}




\section{PENNSYLVANIA.}

\begin{tabular}{|c|c|}
\hline & 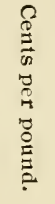 \\
\hline 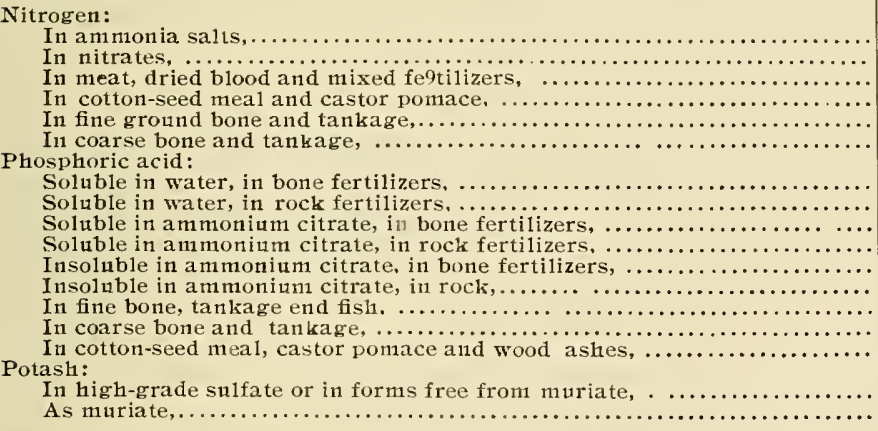 & $\begin{array}{l}16^{1 / 2} \\
14^{1 / 2} \\
16^{1 / 2} \\
16^{1 / 2} \\
11 \\
9 \\
5 \\
3 \\
4^{1 / 2} \\
2^{1 / 2} \\
1^{1 / 2} \\
3^{1 / 2} \\
4^{1 / 2} \\
5^{1 / 4}\end{array}$ \\
\hline
\end{tabular}


Potash in excess of that equivalent to the chlorin present, will be valued as sulfate, and the remainder as muriate.

Nitrogen in mixed fertilizers will be valued as derived from the best sources of organic nitrogen, unless clear evidence to the contrary is obtained.

Phosphoric acid in mixed fertilizers is valued at bone phosphoric acid prices, unless clearly found to be derived from rock phosphate.

Bone is sifted into two grades of fineness: Fine, less than $1-\bar{j} 0$ inch in diameter; coarse, over 1-50 inch in diameter.

The result obtained by the use of this schedule does not cover the items of mixing, bagging, freight and agents' commission. To cover these, allowances are made as follows:

For freight, an allowance of $\$ 2.00$ per ton on all fertilizers.

For bagging, an allowance of $\$ 1.00$ per ton on all fertilizers, except when sold in original packages.

For mixing, an allowance of $\$ 1.00$ per ton on complete fertilizers and rock-and-potash goods.

For agents' commission, an allowance of 20 per cent, is added to the cash values of the goods ready for shipment.

The mean quotation on freight from New York, Philadelphia and Baltimore to Harrisburg, in January, 1897, was $\$ 1.68$ per ton, in lots cf twelve tons or over; in May, 1899, quotations by the Pennsylvania Railroad were: From New York, $\$ 2.40$; from Philadelphia, $\$ 1.70$; and from Baltimore, $\$ 1.55$; mean rate from the three points, $\$ 1.88$.

\section{KENTUCKY.}

Values Used.-In calculating the relative value per ton, the following values have been used:

Soluble and reverted phosphoric acid in mixed fertilizers...66 per lh. Soluble and reverted phosphoric acid in plain acid and unacid-

ulated phosphates, $\ldots \ldots \ldots \ldots \ldots \ldots \ldots \ldots \ldots \ldots \ldots \ldots \ldots \ldots \ldots \ldots$ per $1 \mathrm{~b}$.

Insoluble phosphoric acid in mixed fertilizers, ..........2 per ib. Insoluble phosphoric acid in plain acid phosphates......... Nothing. Phosphoric acid in fine bone, .................4c per lb. Phosphoric acid in medium bone,.................. per lb.

Fine bone is all that passes through a sieve with meshes onctwenty-fifth inch square. Medium bone passes through a sieve with meshes one-sixth inch square, but does not include fine bone. 
Nitrogen in all fertilizers $\ldots \ldots \ldots \ldots \ldots \ldots \ldots \ldots \ldots \ldots \ldots$ per $\mathrm{lb}$.

Potash in all fertilizers, from sulphate,...........6 per lb. Potash in all fertilizers, from muriate,............. 5 c per ib.

The term "Potash from muriate" does not indicate necessarily that the manufacturers used muriate of potash in furnishing the potash; they may have used sulphate of potash, or other salts of potasb, but in all fertilizers where the term "Potash from murate' is used there is enough chlorine present to combine with the potash, either from salt in the tankage used, or the potash salts used, as muriate, kainit, carnallite, etc. As the objection to the use of muriate of potash arises from the chlorine present in this salt, it llkewise follows that chlorine in a fertilizer is objectionable, whether put in with the potash or otherwise. The using of sulphate of potash where there is chlorine present in other ingredients of the fertilizer will not obviate the injurious effect of the chlorine, and therefore we take this method of showing chlorine present by designating the potash as "from muriate."

\section{VIRGINIA.}

\section{In Unmixed or Raw Materials.}

Available Phosphoric Acid, ................... per lis. Phosphoric Acid in Animal Bone,.............. $3 \frac{1}{2} \mathrm{c}$ per lb.

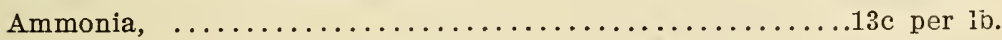

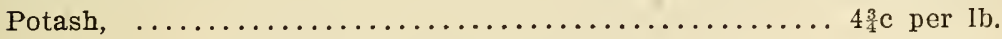

\section{In Mixed Fertilizers.}

Available Phosphoric Acid, ................. $\frac{1}{2} \mathrm{c}$ per lb.

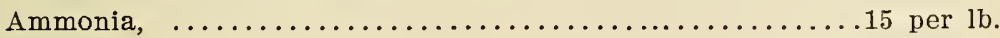

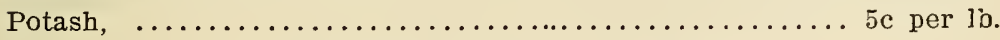

\section{How Relative Values are Calculated.}

In the calculation of relative values it is only necessary to remember that so many per cent. means the same number of pounds per hundred, and that there are twenty-hundred pounds in one ton $(100 \times 20--$ 2,000 pounds-1 ton). Therefore, to find the value per ton, multiply the per cent. of each ingredient by 20 , which gives the number of pounds of each incredient in a ton, then multiply this result by the 
price per pound of that ingredient, then add up the figures thus obtained for each ingredient, and the sum is the relative value per ton.

As an example, take 8-2- fertilizer, which means that the fertilizer contains 8 per cent, available phosphoric acid, 2 per cent, ammonia, and 2 per cent, potash.

\section{OHIO.}

\section{Table No. 1-Mixed Fertilizers, with Potash.}

Ammonia, $12 \frac{1}{2}$ cents per pound, or $\$ 2.50$ per unit.

Available phosphorics acid, 5 cents per pound, or $\$ 1.00$ per unit.

Insoluble phosphoric acid, in bone, $2 \frac{1}{2}$ cents per pound, or 50 cents per unit.

Potash (actual) from sulphate, $5 \frac{3}{4}$ cents per pound, or $\$ 1.15$ per unit.

Potash (actual) from muriate, 5 cents per pound, or $\$ 1.00$ per unit.

Table No. 2-Mixed Fertilizers, Without Potash.

Ammonia, $12 \frac{1}{2}$ cents per pound, or $\$ 2.50$ per unit.

Available phosphoric acid, 5 cents per pound, or $\$ 1.00$ per unit.

Insoluble phosphoric acid, in bone, $2 \frac{1}{2}$ cents per pound, or 50 cents per unit.

Insoluble phosphoric acid, in mixed animal and mineral, 1 cent per pound, or 20 cents per unit.

Table No. 3-Dissolved Bone.

Ammonia, $12 \frac{1}{2}$ cents per pound, or $\$ 2.50$ per unit.

Available phosphoric acid, 5 cents per pound, or $\$ 1.00$ per unit.

Insoluble phosphoric acid, $2 \frac{1}{2}$ cents per pound, or 50 cents per unit.

Table No. 4-Rock Phosphate.

Available phosphoric acid, 5 cents per pound, or $\$ 1.00$ per unit.

\section{Table No. 5-Rock Phosphate and Potash.}

Available phosphoric acid, 5 cents per pound, or $\$ 1.00$ per unit.

Potash (actual) from sulphate, $5 \frac{3}{4}$ cents per pound, or $\$ 1.15$ per unit.

Potash (actuai) from muriate, 5 cents per pound, or $\$ 1.00$ per unit. 
Table No. 6-Tankage.

Ammonia, 9 cents per pound, or $\$ 1.80$ per unit.

Total phosphoric acid, 3 cents per pound, or 60 cents per unit.

Table No. 7-Tankage and Potash.

Ammonia, 9 cents per pound, or $\$ 1.80$ per unit.

Total phosphoric acid, 3 cents per pound, or 60 cents per unit.

Potash (actual) from sulphate, $5 \frac{3}{4}$ cents per pound, or $\$ 1.15$ per unit.

Potash (actual) from muriate, 5 cents per pound, or $\$ 1.00$ per unit.

Table No. 8-Bones.

Ammonia, $12 \frac{1}{2}$ cents per pound, or $\$ 2.50$ per unit.

Phosphoric acid in "fine" bone, $3 \frac{3}{4}$ cents per pound, or 75 cents per unit.

Phosphoric acid in "medium" bone, 3 cents per pound, or 60 cents per unit.

Potash, if found present, valued same as in Table No. 1.

\section{Table No. 9-Potash Salts.}

Potash (actual) from sulphate, $5 \frac{3}{4}$ cents per pound, or $\$ 1.15$ per unit.

Potash (actual) from muriate, 5 cents per pound, or $\$ 1.00$ per unit.

Table No. 10-Nitrate of Soda.

Ammonia, $12 \frac{1}{2}$ cents per pound, or $\$ 2.50$ per unit.

Table No. 11-Precipitated Phosphate.

Available phosphoric acid, 5 cents per pound, or $\$ 1.00$ per unit.

Note.- "Unit" is a trade expression used in speaking of the ingredients of commercial fertilizers, and means one percentum of a ton, or twenty pounds; e. g., ammonia, $12 \frac{1}{2}$ cents per pound, or $\$ 2.50$ per unit; that is, $\$ 2.50$ for twenty pounds. 


\section{Analysis of Commercial Fertilizers--1902.}

GOODS OF

AMERICAN AGRICULTURAL CHEMICAL COMPANY,

New York and Baltimore.

4402 GEM ALKALINE BONE.. G. T. Hodges, Shepherdstown. Guarantee: Phosphoric acid, soluble, 4; reverted, 2 : insoluble, 1 ; total, 7 ; available, 6 ; potash, 3 ; phosphorie acid from dissolved phosphate rock; potash from kainit. Found: Phosphoric acid, soluble, 3.89 ; reverted, 3.88 ; insoluble, 0.49 ; total, 8.26 ; available, 7.77 ; potash, 3.10 ; *chlorine, 5.1. RemarkChlorine excessive.

4447 GEM ALKALINE BONE.. C. W. Siever, Keyser. Guarantee-(As above). Found: Phosphoric acid, soluble, 5.77; reverted, 2.95; insoluble, 0.35 ; total, 9.07 ; available, 8.72 ; potash, 2.42; *hlorine, 7.6. Remark-Chlorine excessive.

4454 GEM ALKALINE BONE. MIcKown \& Buscy, Martinsburg. Guarantee-(As above). Found: Phosphoric acid, soluble, 5.51 ; reverted, 3.02 ; insoluble, 0.36 ; total, 8.89 ; available, 8.53 ; potash, 3.17 ; *chlorine, 6.8 . Remark-Chlorine excessive.

4492 GEM ALKALINE BONE. J. W. Hedrick, Alderson. Guarantee-(As above). Found: Phosphoric acid, soluble, 1.61; reverted, 5.06 ; insoluble, 0.78 ; total, 7.45 ; available, 6.67; potash, 3.11; *hlorine, 6.0. Remark-Chlorine excessive. 
4519 GEII ALKALINE BONE. Payne Bros., Seebert. Guarantee-(As above). Found: Phosphoric acid, soluble, 1.24; reverted, 5.94; insoluble, 0.74 ; total, 7.92 ; available, 7.18 ; potash, 3.05; *chlorine, 5.4. Remark-Chlorine excessive.

4576 GEM ALKALINE BONE. J. H. Miller \& Sons, Martinsburg. Guarantee-(As above). Found: Phosphoric acid, soluble, 6.01 ; reverted, 4.50 ; insoluble, 1.30 ; total, 11.81 ; available, 10.51 ; potash, 2.02 ; *hlorine, 3.7 .

4414 REGULAR CORN FERTILIZER. Washington \& Alexander, Charles Town. Guarantee-Phosphoric acid, soluble, 4 ; reverted, 2 ; insoluble, 1 ; total, 7 ; available, 6 ; potash, 3; phosphoric acid from dissolved phosphate rock; potash from kainit. Found: Phosphoric acid, soluble, 3.45; reverted, 4.08; insoluble, 0.38 ; total, 7.91 ; available, 7.53 ; potash, 3.20 ; chlorine, 5. Remark-Chlorine excessive.

4434 BONE MEAL. W. L. Cole, Clarksburg,. Guarantee-Total phosphoric acid, 14; nitrogen, 1.65; phosphoric acid from animal bone, nitrogen from animal bone. Found: Total phosphoric acid, 18.86; nitrogen, 1.88 ; availability of nitrogen, 86.

4479 BONE MEAL. W. L. Cole, Clarksburg. Guarantee -As above). Found: Total phosphoric acid, 17.53; nitrogen, 1.80 ; availability of nitrogen, 84 .

4544 FINE GROUND BONE. C. W. Siever, Keyser. Guarantee-Total phosphoric acid, 23; nitrogen, 2.47 ; phosphoric acid from animal bone; nitrogen from animal bone. Found: Total phosphoric acid, 22.99 ; nitrogen, 3.10 ; availability of nitrogen, 88 .

4611 FINE GROUND BONE. - - - Herring, Kingwood. Guarantee-(As above). Found: Total phosphoric acid, 21.26 ; nitrogen, 1.92 ; availability of nitrogen, 85. 
4561 PURE GROUND BONE. A. G. Chrislip, Philippi. Guarantce-Total phosphoric acid, 20 ; nitrogen, 3.29 ; phosphoric acid from animal bone; nitrogen from animal bone. Found: Total phosphoric acid, 19.45 ; nitrogen, 3.45 ; availability of nitrogen, 73 .

4537 W. \& A. SPECIAL FALL MIXTURE. Washington \& Alexander, Charles Town. Guarantee-Phosphoric acid, soluble,; reverted, 2 ; insoluble, 1 ; total, 9 ; available, 8 ; potash, 1 ; phosphoric acid from dissolved phosphate rock; potash from kainit. Found: Phosphoric acid, soluble, 5.57; reverted, 2.12 ; insoluble, 1.48; total, 9.16 ; arailable, 7.68 ; potash, 1.32 ; chlorine, 3.6.

4645 BRADLEY'S DISSOLVED BONE WITH POTASH. A. P. Russell \& Company, Buckhannon. GuaranteePhosphoric acid, soluble, 6; reverted, 2; insoluble, 1; total, '; available, 8 ; nitrogen, 1.03 ; potash, 2 ; Phosphoric acid from dissolved phosphate rock and dissolved animal bone; nitrogen from animal bone, fish and tankage; potash from kainit. Found: Phosphoric acid, soluble, 2.57; reverted, 6.29; insoluble, 1.78; total, 10.61 ; available, 8.86 ; nitrogen, 0.92 ; potash, 2.45 ; chlorine, 2.3 ; availability of nitrogen, 86 .

4373 BRADLEY'S BEAN AND POTATO PHOSPHATE. O. R. Carmen, Wellsburg. Guarantee-Phosphoric acid, soluble, 6 ; reverted, 2 ; insoluble, 1 ; total, 9 ; available, 8 ; nitrogen, 0.82 ; potash, 4; phosphoric acid from dissolved phosphate rock, fisil and tankage; nitrogen from dissolved fish and tankage; potash from kainit and manure salts. Found: Phosphoric acid, soluble, 7.41; reverted, 2.21; insoluble, 1.55; total, 11.17 ; available, 9.62; nitrogen, 1.04 ; potash, 3.89 ; chlorine, 1.4 ; availability of nitrogen, 80 .

462S BRADLEY'S NIAGARA PHOSPHATE. O. R. Carmen, Wellsburg. Guarantee-Phosphoric acid, soluble, 5; 
reverted, 2; insoluble, 1 ; total, 8 ; available, 7 ; nitrogen, 0.82 ; potash, 1; phosphoric acid from dissolved phosphate rock, fish, and tankage; nitrogen from dissolved fish and tankage; potash from kainit. Found: Phosphoric acid, soluble, 3.94; reverted, 3.86; insoluble, 1.27; total, 9.07 ; available, 7.80 ; nitrogen, 1.01 ; potash, 1.24; chlorine, 1.8 ; availability of nitrogen, 77 .

4374 BRADLEY'S ALKALINE BONE. O. R. Carmen, Wellsburg. Guarantee-Phosphoric acid, soluble, 8; reverteci, 2 ; insoluble, 1 ; total, 11 ; available, 10 ; potash, 2 ; phosphoric acid from dissolved phosphate rock; potash from kainit. Found: Phosphoric acid, soluble, 8.34; reverted, 2.60; insoluble, 1.00 ; total, 11.94 ; available, 10.94 ; potash, 2.32 ; chlorine, 1.2 ; $R \epsilon$ mark-Source of potash equivalent to muriate.

4491 BRADLEY'S ALKALINE BONE. J. W. Hedrick, Alderson. Guarantee-(As above). Found: Phosphoric acid, soluble, 5.18 ; reverted, 5.57 ; insoluble, 1.03 ; total, 11.78; available, 10.75 ; potash, 2.02 ; chlorine, 2.7.

4646 BRADLEY'S ALKALINE BONE. A. P. Russell \& Co., Buckhannon. Guarantee-(As above). Found: Phosphoric acid, soluble, 5.58; reverted, 6.10 ; insoluble, 0.96 ; total, 12.64; available, 11.68 ; potash, 2.14 ; chlorine, 3.1.

4490 BRADLEY'S SOLUBLE DISSOLVED BONE. J. W. Hedrick, Alderson. Guarantee-Phosphoric acid, soluble, 12 ; reverted, 2 ; insoluble, 1 ; total, 15 ; available, 14 ; phosphoric acid from dissolved phosphate rock. Found: Phosphoric acid, soluble, 10.61 ; reverted, 4.63 ; insoluble, 1.72 ; total, 16.96 ; available, 15.24 .

4629 BRADLEY'S SOLUBLE DISSOLVED BONE. O. R. Carmen, Wellsburg. Guarantee-(As above). Found: Phosphoric acid, soluble, 11.51; reverted, 4.38 ; insoluble, 1.09; toteì, 16.98 ; available, 15.89 . 
4382 CANTON CHEMICAL POTATO MANURE. Armstrong, Chrislip \& Co., Buckhannon. Guarantee-Phosphoric acid, soluble, 4; reverted, 2 ; insoluble, 1 ; total, 7 ; available, 6 ; nitrogen, 1.23; potash, 5 ; phosphoric acid from dissolved phosphate rock and dissolved animal bone; nitrogen from dissolved animal bone, fish, and tankage; potash from kainit and manure salts. Found: Phosphoric acid, soluble, 4.25 ; reverted, 3.00 ; insoluble, 1.51 ; total, 8.76 ; available, 7.25 ; nitrogen, 1.34 ; potash, 5,65 ; chlorine, 1.7 ; availability of nitrogen, 84 .

4413 CANTON CHEMICAL POTATO MANURE. Washington \& Alexander, Charles Town. Guarantce-(As above). Found: Phosphoric acid, soluble, 3.24; reverted, 4.49; insoluble, 1.46 ; total, 9.19 ; available, 7.73 ; nitrogen, 1.45 ; potash, 5.24 ; chlorine, 1.5 ; availability of nitrogen, 78 .

\section{CANTON CHEMICAL POTATO MANURE. C.} W. Siever, Keyser. Guarantee-(As above). Found: Phosphoric acid, soluble, 3.22 ; reverted, 3.65 ; insoluble, 0.96 ; total, 7.83 ; available, 6.87 ; nitrogen, 1.50 ; potash, 4.85 ; chlorine, $2 . .9$; availability of nitrogen, 80 .

\section{CANTON CIIEMCAL GAME GUANO. W. L.} Cole, Clarksburg. Guarantee-Phosphoric acid, soluble, 6; reverted, 2 ; insoluble, 1 ; total, 9 ; available, 8 ; nitrogen, 1.65 ; potash, 2; phosphoric acid from dissolved phosphate rock and dissolved animal bone; nitrogen from dissolved animal bone, fish, and tankage; potash from kainit. Found: Phosphoric acid, soluble, 7.20 ; reverted, 3.70 ; insoluble, 1.69 ; total, 12.59 ; available, 10.90 ; nitrogen, 1.76 ; potash, 2.01 ; chlorine, 1.6 ; availability of nitrogen, 83.

4583 CANTON CIEMICAL GAIE GUANO. R. P. Floyd, Mannington. Guarantee-Phosphoric acid, soluble, 6; reverted, 2; insoluble, 1; total, 9; available, 8; nitrogen, 1.65; potash, 2; phosphoric acid from dissolved phosphate rock and, 
dissolved animal bone; nitrogen from dissolved animal bone, fish, and tankage; potash from kainit. Found: Phosphoric acir, soluble, 4.64 ; reverted 4.59 ; insoluble, 1.89 ; total, 11.12 ; available, 9.23 ; nitrogen, 1.79 ; potash, 2.29 ; chlorine, 3.07 ; availability of nitrogen, 89 .

4380 CANTON CHEMICAL SPECIAL WHEAT. CORN AND GRASS FERTILIZER. Armstrong, Chrislip \& Co., Buckhannon. Guarantee-Phosphoric acid, soluble, 7 ; reverterl, 2 ; insoluble, 1 ; total, 10 ; available, 9 ; nitrogen, 0.82 ; potash, 2 ; phosphoric acid from dissolved phosphate rock and dissolved animal bone; nitrogen from dissolved fish and tankage; potash from kainit. Found: Phosphoric acid, soluble, 7.85; reverted, 1.73 ; insoluble, 1.06 ; total, 10.64 ; available, 9.58 ; nitrogen, 1.03 ; potash, 2.45; chlorine, 2.3 ; availability of nitrogen, 80 .

4445 CANTON CHEMICAL SPECIAL WHEAT, CORN AND GRASS FERTILIZER. C. W. Siever, Keyser. Guarantee-(As above). Found: Phosphoric acid, solubie, 6.92 ; reverted, 2.29 ; insoluble, 0.74 ; total, 9.95 ; available, 9.21 ; nitroger, 1.04 ; potash, 2.49 ; chlorine, .4 .4 ; availability of nitrogen, 75.

4462 CANTON CHEMICAL SPECIAL WHEAT, CORN AND GRASS FERTILIZER. W. H. Brady, Berkeley Spring: Guarantee-(As above). Found: Phosphoric acid, soluble, 8.53; reverted, 0.62 ; insoluble, 1.51 ; total, 10.66 ; available, 9.15 ; ni- 。 trogen, 0.94 ; potash, 2.07 ; chlorine, 1.9 ; availability of nitrogen, 81.

4532 CANTON CHEMICAL SPECIAL WHEAT, CORN AND GRASS FERTILIZER. Washington \& Alexander, Charles Town. Guarantee-(As above). Found: Phosphoric acid, soluble, 7.06 ; reverted, 2.63; insoluble, 1.45; total, 11.14; available, 9.69 ; nitrogen, 0.95 ; potash, 2.08 ; chlorine, 2.5 ; availability of nitrogen, 85 .

4557 CANTON CHEMICAL SPECIAL WHEAT, CORN 
AND GRASS FERTILIZER. J. M. Hagerty, Farmington. Guarantee-(As above). Found: Phosphoric acid, soluble, 6.98; reverted, 2.81 ; insoluble, 2.14 ; total, 11.96 ; available, 9.82 ; nitrogen, 1.17 ; potash, 2.06 ; chlorine, 2.5 ; availability of nitrogen, 81 .

\section{CANTON CIEMICAL MARROIV BRAND CROP} GROWER. Armstrong, Chrislip \& Co., Buckhannon. Guarantee-Phosphoric acid, soluble, 6; reverted, 2; insoluble, 1; totai, 9 ; available, 8 ; nitrogen, 0.82 ; potash, 1 ; phosphoric acid frou dissolved phosphate roek and dissolved animal bone; nitrogen from dissolved fish and tankage; potash from kainit. Found: Phosphoric acid, soluble, 8.35; reverted, 1.82; insoluble, 0.91; total, 11.08 ; available, 10.17 ; nitrogen, 1.06 ; potash, 1.40 ; chlorine, 2.6 ; availability of nitrogen, 78 .

\section{CANTON CHEMICAL HARROW BRAND CROP} GROWER. W. L. Cole, Clarksburg. Guarantee-(As above). Found: Phosphorie acid, soluble, 7.38; reverted, 2.62; insolublc; 1.33 ; total, 11.33 ; available, 10.00 ; nitrogen, 0.95 ; potash, 1.24 ; chlorine, 2.9; availability of nitrogen, 75 .

\section{CANTON CIIEMICAL IIARROW BRAND CROP'} GROWER. C. W. Siever, Keyser. Guarantee-(As above). Found: Phosphoric acid, soluble, 5.35; reverted, 3.87; insoluble, 0.67 ; total, 9.89 ; available, 9.22 ; nitrogen, 0.96 ; potash, 1.35 ; chlorine, 8.2; availability of nitrogen, 85. Remark-Chlorine excessive.

4478 CANTON CHEMICAL IIARROW BRAND CROP GROWER. W. L. Cole, Clarksburg. Guarantee-(As above). Found: Phosplioric acid, soluble, 3.24; reverted, 5.74; insoluble, 1.87 ; total, 10.85 ; available, 8.28 ; nitrogen, 1.04 ; potash, 1.21 ; chlorine, 5.2; availability of nitrogen, 80. Remark-Chlorine excessive. 
GROWER. J. M. Hagerty, Farmington. Guarantee-(As above). Found: Phosphoric acid, soluble, 3.01; reverted, 5.96; insoluble, 1.85 ; total, 10.82 ; available, 8.97 ; nitrogen, 1.05 ; potash, 1.86 ; chlorine, 2.9 ; availability of nitrogen, 86 .

4444 CANTON CHEMICAL SOLUBLE BONE AND) POTASH. C. W. Siever, Keyser. Guarantee-Phosphoric acid, soluble, 8 ; reverted, 2 ; insoluble, 1 ; total, 11 ; available, 10 ; potash, 2; phosphoric acid from dissolved phosphate rock, potash from kainit. Found: Phosphoric acid, soluble, 1.82; reverted, 9.05 ; insoluble, 1.87 ; total, 12.74 ; available, 10.87 ; potash, 1.99 ; chlorine, 3.4 .

4392 CANTON CHEMICAL SOLUBLE BONE AND POTASH. Armstrong, Chrislip \& Co., Buckhannon. Guarantee-(As above). Found: Phosphoric acid, soluble, 3.97 ; reverted, 7.21 ; insoluble, 1.70 ; total, 12.83 ; available, 11.18 ; potash, 2.40 ; chlorine, 3.8 .

4480 CANTON CHEMICAL SOLUBLE BONE AND POTASH. W. L. Cole, Clarksburg. Guarantee-(As above). Found: Phosphoric acid, soluble, 6.65; reverted, 4.05; insoluble, 1.45 ; total, 12.15 ; available, 10.70 ; potash, 1.92 ; chlorine, 3.4 .

4543 CANTON CHEMICAL SOLUBLE BONE AND POTASH. C. W. Siever, Keyser. Guarantee-(As above). Found: Phosphoric acid, soluble, 4.45; reverted, 5.58; insoluble, 1.66 ; total, 11.69; available, 10.03 ; potash, 1.92 ; chlorine, 4.00 .

. 4582 CANTON CHEMICAL SOLUBLE BONE AN]) POTASH. R. P. Floyd \& Son, Mannington. Guarantee-(As above. Found: Phosphoric acid, soluble, 6.64; reverted, 4.05; insoluble, 1.51 ; total, 12.20 ; available, 10.69 ; potash, 1.82 ; chlorine, 3.7 .

4383 CANTON CHEMICAL DISSOLVE'D S. C. BONE. Armstrong, Chrislip \& Co., Buckhannonon. Guarantee-Phos- 
phoric acid, soluble, 12.00 ; reverted, 2.00 ; insoluble, 1.00 ; total, 15.00: available, 14.00: phosphoric acid from dissolved phosphate rock. Found: Phosphoric acid, soluble, 14.42; reverted, 1.76 ; insoluble, 0.18 ; total, 16.36 ; available, 16.18 .

\section{CANTON CHEIICAL DISSOLTED S. C. BONE.} Washington \& Alexander, Charles Town. Guarantee-(As above). Found: Phosphoric acid, soluble, 13.43; reverted, 3.08; insoluble, $0.4 \bar{\imath}$; total, 16.98 ; available, 16.51 .

4461 CANTON CHEMIC.1L DISSOLTED S. C. BONE. W. H. Brady, Berkeley Springs. Guarantec-(As above). Found: Phosploric acid, soluble, 13.56; reverted, 2.99 ; insoluble, 0.22 ; total, 16.87 ; available, 16.65 .

4531 CANTON CHEMICAL DISSOLTED S. C. BONE. Washington \& Alexander, Charles Town. Guuarantee-(As above). Found: Phosphoric acid, soluble, 13.15; reverted, 0.34 ; insoluble, 3.83; total, 17.32; available, 13.49.

4571 CANTON CHEIICAL DISSOLTED S. C. BONE. L. P. Licklider, Martinsburg. Guarantce-(As above). Found: Phosphoric acid, soluble, 12.70 ; reverted, 3.65; insoluble, 0.32 ; total, 16.76 ; available, 16.44 .

\section{CANTON CHEMICAL SOLUBLE ALKALINE} BONE. Washington \& Alexander, Charles Town. GuarantecPhosphoric acid, soluble, 10.00; reverted, 2.00; insoluble, 1.00; total, 13.00 ; available, 12.00 ; potash, 3.00 ; phosphoric acid from dissolved phosphate rock, potash from kainit and manure salts. Found: Phosphoric acid, soluble, 8.33; reverted, 4.92; insoluble, 0.46 ; total, 13.71 ; available, 13.25 ; potash, 3.04 ; chlorine, 1.8.

4379 CLETELAND DRIER FOREST CITY BUCKEYE. Bishop \& Barb, Jane Lew. Guarantec-Phosphoric acid, soluble, 7.00 ; reverted, 2.00 ; insoluble, 1.00 ; total, 10.00 ; available, 9.00 ; nitrogen, 2.47 ; potash, 2.00 ; phosphoric acid from dis- 
solved phosphate rock and animal bone; nitrogen from dissolved animal bone, blood and azotine; potash from muriate and manure salts. Found: Phosphoric acid, soluble, 8.61; reverted, 1.85; insoluble, 1.65; total, 12.11; available, 10.46; nitrogen, 1.73; potash, 2.49; chlorine, 0.8 ; availability of nitrogen 89.

\section{CLEVELAND DRYER FOREST CITY BUCF-} EYE. J. W. Feather, Kingwood. Guarantee-(As above): Found: Phosphoric acid, soluble, 7.61; reverted, 3.29; insoluble, 1.45; total, 12.35; available, 10.90 ; nitrogen, 1.70 ; potash, 2.21 ; chlorine, 1.0 ; availability of nitrogen, 91.

4400 CLEVELAND DRYER PHOSPHO BONE. J. W. Feather, Kingwood. Guarantee-Phosphoric acid, soluble, 8.00; reverted, 2.00 ; insoluble, 1.00 ; total, 11.00 ; available, 10.00 ; nitrogen, 0.82 ; potash, 1.00 ; phosphoric acid from dissolved phosphate rock and dissolved animal bone; nitrogen from dissolved fish and tankage; potash from kainit. Found: Phosphoric acir, soluble, 8.88 ; reverted, 221 ; insoluble, 1.09 ; total, 12.18 ; available, 11.09 ; nitrogen, 1.12 ; potash, 1.27 ; chlorine, 2.9 ; availability of nitrogen, 84 .

4464 CLEVELAND DRYER PHOSPHO BONE. J. W. \& Jeff Miller, Spencer. Guarantee-(As above). Found: Phosphoric acid, soluble, 7.28 ; reverted, 3.85 ; insoluble, 1.78 ; tota 12.91; available, 11.13 ; nitrogen, 0.93 ; potash, 1.16 ; chlorine, 1.1 ; availability of nitrogen, 77 .

4633 CLEVELAND DRYER PHOSPHO BONE. S. J. Taylor, Toll Gate. Guarantee-(As above). Found: Phosphoric acid, soluble, 8.33 ; reverted, 3.70 ; insoluble, 1.38 ; total, 13.4.1; available, 12.03 ; nitrogen, 1.04 ; potash, 1.16 ; chlorine, 2.6 ; availability of nitrogen, 78 .

4631 CLEVELAND DRYER HORSEHEAD PHOSPHATE. S. J. Taylor, Toll Gate. Guarantee-Phosphoric acid, soluble, 8.00 ; reverted, 2.00 ; insoluble, 1.00 ; total, 11.00 ; 
available, 10.00; phosphoric acid from dissolved phospinate rock; Found: Phosphoric acid, soluble, 2.32; reverted, 9.26 ; insoluble, 1.70 ; total, 13.28 ; available, 11.58.

4378 CLEVELAND DRYER HORSEHEAD .PHOSPHATE WITI POTASH. Bishop \& Barb, Jane Lew. Guarantec-Phosphoric acid, soluble, 8.00; reverted, 2.00; insoluble, 1.00 ; total, 11.00 ; available, 10.00 ; potash, 2.00 ; phosphoric acid from dissolved phosphate rock; potash from kainit. Found: Phosphoric acid, soluble, 9.59 ; reverted, 2.09 ; insoluble, 0.42 ; total, 12.10 ; available, 11.68 ; potash, 2.13 ; chlorine, 2.7.

4398 CLEVELAND DRYER HORSEHEAD PHOSPHATE WITH POTASII. J. W. Feather, Kingwood. Guarantee-(As above). Found: Phosphoric acid, soluble, 8.02 ; reverted, 3.06 ; insoluble, 0.38 ; total, 11.46 ; available, 11.08 ; potash, 2.04; chlorine, 3.0.

4465 CLEVELAND DRYER HORSEHEAD PHOSPIIATE WITH POTASII. J. W. \& Jeff Miller, Speneer. Guarantee-(As above). Found: Phosphorie acid, soluble, 7.13; reverted, 2.22 ; insoluble, 1.73 ; total, 12.19 ; available, 10.46 ; potash, 1.62 ; chlorine, 1.1.

4620 CLEVELAND DRYER HORSEHEAD PHOSPHATE WITH POTASH. Bishop \& Barb, Jane Lew. Guaranee-(As above). Found: Phosphoric acid, soluble, 6.27 ; reverted, 3.05 ; insoluble, 1.54 ; total, 10.86 ; available, 9.32 ; potash, 2.12 ; chlorine, 4.00 .

4397 CLEVELAND DRYER XXX PHOSPHATE. J. W. Feather, Kingwood. Guarantee-Phosphoric acid, soluble, 12.00 ; reverted, 2.00 ; insoluble, 1.00 ; total, 15.00 ; available, 14.00 ; phosphoric acid from dissolved phosphate rock. Found: Phosphoric acid, soluble, 13.56; reverted, 2.94; insoluble, 0.26; total, 16.77 ; available, 16.51. 
4632 CLEVELAND DRYER XIX PHOSPHATE.. is. J. Taylor, Toll Gate. Guarantee-(As above). Found: Phosphoric acid, soluble, 10.59 ; reverted, 6.12 ; insoluble, 0.82 ; total, 17.53 ; available, 16.71 .

4436 DETRICK'S SOLUBLE BONE PHOSPHATL AND POTASH. Bush \& Sleeth, Toll Gate,..GuaranteePhosphoric acid, soluble, 8.00; reverted, 2.00; insoluble, 1.00; total, 11.00; available, 10.00 ; potash, 2.00 ; phosphoric acid fror:1 dissolved phosphate rock; potash from kainit. Found: Phosphoric acid, soluble, 8.21; reverted, 2.63; insoluble, 0.49; total, 11.33 ; available, 10.84 ; potash, 2.12 ; chloride, 2.7.

4541 DETRICK'S SOLUBLE BONE PHOSPHATE AND POTASH. Geo. Brinkman, Grafton. Guarantee-(As. above). Found: Phosphoric acid, soluble, 4.95; reverted, 5.49; insoluble, 1.06; total, 11.50; available, 10.44; potash, 1.54 ; chlorine, 4.7.

4595 DETRICK'S SOLLBLE BONE PHOSPHATE AND POTASH. H. J. Heck, Barrickville. Guarantee-(As above). Found: Phosphoric acid, soluble, 3.91; reverted, 7.66; insoluble, 1.59 ; total, 13.16 ; available, 11.57 ; porash, 2.44 ; chlorine, 1.9 .

4596 DETRICK'S KANGAROO KOMPLETE KOHLPOUND. H. J. Heck, Barrickville. Guarantee-Phosphor:e acid, soluble, 6.00; reverted, 2.00; irsoluble, 1.00; total, 9.00; zvailable, 8.00 ; nitrogen, 1.65 ; potash, 3.00 ; phosphoric acid inom dissolved phosphate rock and animal bone; nitrogen from dissolver animal bone, fish, and tarkage; potash from kainit and manure salts. Found: Phosphoric acid, soluble, 5.I0; reverted, 6.30 ; insoluble, 2.57 ; total, 13.97 ; available, 11.40 ; nitrogen, 1.89 ; potash, 2.83 ; ehlorine, 1.7.

4573 DETRICK'S DISSOLVED S. C. BONE. L. P. Licklider, Nartinsburg. Guarantee-Phosphoric acid, soluble. 
12.00 ; reverted, 2.00 ; insoluble. 1.00 ; total, 15.00 ; availab?e, 14.00 ; phosphoric acid rfom dissolved phosphate rock. Found: Phosphoric acid, soluble, 12.32; reverted, 4.29; insoluble, 0.46 ; total, 17.07 ; available, 16.61 .

4597 DETRICK'S IMPERIAL COMPOUND. H. T. Heck, Barricksville. Guarantee-Plosplıoric acid, soluble, 6.00; reverted, 2.00 ; insoluble, 1.00 ; total, 9.00 ; available, 8.00 ; nitrogen, 0.82 ; potash, 2.00 ; phosphoric acid from dissolved phosphate rock and animal bone; nitrogen from dissolved fish and tankage; potash from kainit. Found: Soluble Phosphoric acid, 5.53 ; reverted, 3.89 ; insoluble, 1.80 ; total, 11.22 ; available, 9.42 ; nitrogen, 1.03 ; potash, 2.39 ; chlorine, 2.7. Availibility of nitrogen, 82 .

\section{GREAT EASTERN UNAMMONIATED WHEAT} SPECIAL. J. M. McIntosh \& Son, Ravenswood. GuaranteePhosphoric acid, soluble, 10.00 ; reverted, 2.00; insoluble, 1.00 ; total, 13.00; available, 12.00;Phosphoric acid from dissolved phusphate rock. Found: Phosphoric acid, soluble, 8.64; reverted, 3.86 ; insoluble, 1.99 ; total, 14.49 ; available, 12.50 .

4613 GREAT EASTERN UNAMMONIATED WHEA' SPECIAL. - - Herring, Kingwood. Guarantee-As above . Found: Phosphoric acid, soluble, 6.58; reverted, 5.75; insoluble, 3.56 ; total, 15.89 ; available, 12.33 .

4439 GREAT EASTERN CORN FERTILIZER. Allt_. der Bros., Toll Gate. Guarantee-Phosphoric acid, soluble, 6.00; reverted, 2.00 ; insoluble, 1.00 ; total, 9.00 ; available, 8.00 ; nitr.sgen, 0.82 ; potash, 4.00 ; phosphoric acid from dissolved phusphate rock; nitrogen from fish and tankage; potash from kainit and manure salts. Found: Phosplioric acid, soluble, 5.18; reverted, 3.50 ; insoluble, 0.72 ; total, 9.40 ; available, 8.68 ; nitrogen, 0.97 ; potash, 3.77 ; chlorine, 3.00 ; availability of nitrogen, 82 . Remark-Source of potash equivalent to kainit. 
4624 GREAT EASTERN CORN FERTILIZER. Lake \& McCarty, Jane Lew. Guarantee-(As above). Found: Phosphoric acid, soluble, 4.70 ; reverted, 3.09 ; insoluble, 1.55 ; total, 9.34; available, 7.79 ; nitrogen, 0.90 ; potash, 4.33. Chlorine, 3.4 ; availability of nitrogen, 71. Remark-Source of potash equivulent to kainit.

4437 GREAT EASTERN VEGETABLE, IINE AND TOBACCO. Allender Bros., Toll Gate. Guarantee-Phosphoric acid, soluble, 6.00 ; reverted, 2.00; insoluble, 1.00 ; total, 9.00 ; available, 8.00 ; nitrogen, 2.06; potash, 3.00 ; phosphoric acid from dissolved phosphate rock and animal bone; nitrogen from dissolved tankage, fish, blood and animal bone; potash from kainit and manure salts. Found: Phosphoric acid, soluble, 6.41; reverted, 2.25; insoluble, 0.69 ; total, 9.35 ; available, 8.66 ; nitrogen, 2.35 ; potash, 2.38 ; chlorine 3 . Availability of nitrogen, 88 . Remark-Source of potash equivalent to kainit.

4614 GREAT EASTERN ENGLISH WHEAT GROWER. - - Herring, Kingwood. Guarantee-Phosphoric acid, soluble, 6 ; reverted, 2 ; insoluble, 1 ; total, 9 ; available, 8 ; nitrogen, 0.82 ; potash, 2 ; phosphoric acid from dissolved phosphate rock and dissolved animal bone; nitrogen from fish and tankage; potash from kainit. Found: Phosphoric acid, soluble, 3.29 ; reverted, 3.98; insoluble, 0.67 ; total, 7.94 ; available, 7.27 ; nitrogen, 0.83 ; potash, 2.05 ; chlorine, 6.8 ; availability of nitrogen, 73 . Remark-Chlorine excessive.

4622 GREAT EASTERN ENGLISH THEAT GROWER. Lake \& McCarty, Jane Lew. Guarantee-(As above). Found: Phosphoric acid, soluble, 3.67 ; reverted, 5.18 ; insoluble, 1.41 ; total, 10.26 ; available, 8.85 ; nitrogen, 0.82 ; potash, 2.06 ; chlorine, 3.04 ; availability of nitrogen, 80 .

4623 GREAT EASTERN SOLUBLE BONE AND POTASH. Lake \& McCarty, Jane Lew. Guarantee-Phosphoric 
acid, soluble, 8 ; reverted, 2 ; insoluble, 1 ; total, 11 ; available, 10 ; potash, 2 ; phosphoric acid from dissolved phosphate rock; potash from kainit. Found: Phosphoric acid, soluble, 3.28 ; revertec, 7.57 ; insoluble, 0.68 ; total, 11.53 ; available, 10.85 ; potash, 1.67 ; chlorine, 3.4 .

4438 GREAT EASTERN SOLUBLE BONE AND POTASH. Allender Bros., Toll Gate. Guarantee-(As above). Found: Phosphoric acid, soluble, 6.08; reverted, 3.31 ; insolublc, 1.96 ; total, 11.35 ; available, 9.39 ; potash, 2.33 ; chlorine, 3.4 .

4612 GREAT EASTERN DISSOLVED BONE. - - Herring, Kingwood. Guarantee-Phosphoric acid, soluble, 12; reverted, 2 ; insoluble, 1 ; total, 15 ; available, 14 ; phosphoric acicl from dissolved phosphate rock. Found: Phosphoric acid, soluble, 9.95 ; reverted, 6.28 ; insoluble, 0.40 ; total, 16.63 ; available, 16.23 .

4584 LAZARETTO BONE COMPOUND. A. G. Chrislip, Philippi. Guarantee-Phosphoric acid, soluble, 7 ; reverted, 2; insoluble, 1 ; total, 10 ; available, 9 ; nitrogen, 1.03 ; potash, 3 ; phosphoric acid from dissolved phosphate rock and dissolved animal bone; nitrogen from dissolved fish and tankage; potash from kainit and manure salts. Founl-Phosphoric acid, soluble, 8; reverted, 2.11; insoluble, 1.24; total, 11.35; available 10.11 ; witrogen, 1.00 ; potash, 3.39 ; chlorine, 1.9 ; availability of nitrogen, 85 .

4606 LAZARETTO BONE COMPOUND. Shaffer \& Brown, Kingwooo. Guarantee-(As above). Found-Phosphoric acid, soluble, 5.74; reverted, 3.79 ; insoluble, 0.72 ; tota!, 10.25 ; available, 9.53 ; nitrogen, 1.30 ; potash, 3.28 ; chlorine, 1.5 ; availability of nitrogen, 76 .

4648 LATARETTO AMMONIATED BONE PHOSPIIATE. W. D. Wright, Lawford. Guarantee-Phosphoric 
acid, soluble, 6 ; reverted, 2 ; insoluble, 1 ; total, 9 ; available, 8 ; nitrogen, 0.82 ; potash, 2 ; phosphoric acid from dissolved phosphate rock and dissolved animal bone, nitrogen from dissolved fish and tankage; potash from kainit. Found: Phosphoric acir, soluble, 4.54 ; reverted, 4.83 ; insoluble, 1.66 ; total, 11.03 ; available, 9.37 ; nitrogen, 0.97 ; potash, 2.16 ; chlorine, 2.5 ; arailability of nitrogen, 78 .

\section{LAZARETTO AMMONIATED BONE PHOÉ.} PHATE. F. B. Drummond \& Co., Buckhannon. Guarantee(As above). Found: Phosphoric acid, soluble, 3.48; reverted, 5.68; insoluble, 1.87 ; total, 11.13 ; available, 9.26 ; nitrogen, 1.19 ; potash, 2.51 ; chlorine, 3.0 ; avilability of nitrogen, 81 .

4610 LAZARETTO ETCELSIOR A. A. A. Shaffer \& Brown, Kingwood. Guarantee-Phosphoric acid, soluble, 5; reverted, 2 ; insoluble, 1 ; total, 8 ; available, 7 ; nitrogen, 0.82 ; potash, 1; phosphoric acid from dissolved phosphate rock and animal bone; nitrogen from dissolved fish and tankage; potash from kainit. Found: Phosphoric acid, soluble, 3.80; reverter, 4.32 ; insoluble, 0.64 ; total, 8.76 ; arailable, 8.12 ; nitrogen, 1.17 ; potash, 2.20; chlorine, 5.5; availability of nitrogen, 77. Remar\%. -Chlorine excessive.

4607 LAZARETTO DISSOLVED BONE PHOSPHATE AND POTASH. Shaffer \& Brown, Kingwood. Guarantee-Phosphoric acid, soluble, 8; reverted, 2 ; insoluble, 1; total, 11 ; available, 10; potash, 2; phosphoric acid from dissolved phosphate rock; potash from kainit. Found: Phosphoric acid, soluble, 7.57 ; reverted, 5.54; insoluble, 0.74 ; total, 13.85 ; available, 13.11 ; potash, 1.89 ; chlorine, 2.9 .

4585 LAZARETTO DISSOLVED BONE PHOSPHATE. A. G. Chrislip, Philippi. Guarantee-Phosphoric acid, soluble, 12 ; reverted, 2 ; insoluble, 1 ; total, 15 ; available, 14 ; phosphoric acid from dissolved phosphate rock. Found: Phosphoric acid, 
soluble, 12.81 ; reverted, 3.91 ; insoluble, 0.78 ; total, 17.50 ; arailable, 16.72 .

\section{LAZARETTO DISSOLTED BONE PHOSPHATE.} Shaffer \& Brown, Kingwood. Guarantec-(As above). Found: Phosphoric acid, soluble, 12.65 ; reverted, 4.00 ; insoluble, 0.91 ; total, 17.56 ; available, 16.65.

4586 LAZARETTO HIGH GRADE DISSOLVED BONL AND POTASH. A. G. Chrislip, Philippi. Guarantee-Phosphoric acid, soluble, 10 ; reverted, 2 : insoluble, 1 ; total, 13 ; available, 12; potash, 5; phosphoric acid from dissolved phosphat:s rock; potash from kainit and double manure salt. Found: Phosphoric acid, soluble, 8.24; reverted, 6.13; insoluble, 0.28; total, 14.93 ; available, 14.67 ; potash, 2.98 ; chlorine, 1.6.

\section{MARYLAND AMMONTATED BONE. J. L. Wood-} yard, Pruntytown. Guarantce-Phosphoric acid, soluble, 6; reverted, 2 ; insoluble, 1 ; total, 9 ; available, 8 ; nitrogen, 1.65 ; potash, 3; phosphoric acid from dissolved phosphate rock and dissolved animal bone; nitrogen from dissolved animal bone, fish, and tankage; potash from kainit and manure salts. Found: Phosphoric acid, soluble, 8.02 ; reverted, 1.33 ; insolnble, 3.33 ; r.1tal, 12.68 ; available, 9.35 ; nitrogen, 1.79 ; potash, 3.99 ; chlorine. 1.4 ; availability of nitrogen, 83 .

4423 MARYLAND "O. K." LMMONTATED FERTILIZER. G. W. Harvey, Tumnelton. Guarantee-Phosphoric acid, soluble, 6 ; reverted, 2 ; insoluble, 1 ; total, 9 ; available, 8 ; nitrogen, 0.82 ; potash, 2 ; phosphoric acid from dissolved rock and dissolved animal bone; nitrogen from dissolved fish and tankage; potash from kainit. Found: Phosplioric acid, soluble, 7.22; reverted, 2.17 ; insoluble, 1.59 ; total, 10.98 ; available, 9.39 ; nitrogen, 1.03 ; potash, 2.18 ; chlorine, 2.2 ; availability of nitrogen, 92.

4419 MARYLAND TORNADO FERTILIZER. J. T. Woodyard, Pruntytown. Guarantec-Phosphoric acid, soluble, 
10 ; reverted, 2; insoluble 1; total, 13 ; available, 12 ; potash, 5 ; phosphoric acid from dissolved phosphate rock; potash from kainit and manure salts. Found: Phosphoric acid, soluble, 8.14; reverted, 6.55 ; insoluble, 0.50 ; total, 15.19 ; available, 14.69 ; potash, 4.81; chlorine, 1.0. Remark-Source of potash equivalent to muriate.

4422 IIARLAND TORNADO FERTILIZER.. Sent in by O. E. Darnell, Pruntytown. Guarantee-(As above). Founc: Phosphoric acid, soluble, 7.77 ; reverted, 7.94 ; insoluble, 0.36 ; total, 15.07; available, 14.71; potash, 5.14; chlorine, 0.9. Remarli - Source of Potash equivalent to muriate.

4424 MARYLAND TORNADO FERTILIZER. G. W. Harvey, Tumnelton. Guarantee-(As above). Found: Phosphoric acid, soluble, 11.40 ; reverted, 3.02 ; insoluble, 0.24 ; total, 14.66 ; available, 14.42 ; potash, 5.33 ; chlorine, 0.8. RemarkSource of potash equivalent to muriate..

4518 MARYLAND TORNADO FERTILIZER. Payne Brothers, Seebert. Guarantee-(As above). Found: Phosphoric acid, soluble, 7.83 ; rererted, 4.93 ; insoluble, 0.86 ; total, 13.62 ; available, 12.76 ; potash, 4.85 ; chlorine, 1.8 .

4553 MARYLAND TORNADO FERTILIZER. J. L. Woodyard, Pruntytown. Guarantee-(As above). Found: Phosphoric acid, soluble, 8.15 ; reverted, 4.22 ; insoluble, 1.04 ; total, 13.41 ; available, 12.37 ; potash, 5.01 ; chlorine, 1.6.

4401 MARYLAND BONO SUPER-PHOSPHATE. G. T. Hodges, Shepherdstown. Guarantee-Phosphoric acid, solnble, 8 ; reverted, 2 ; insoluble, 1 ; total, 11 ; available, 10 ; potash, 2 ; phosphoric acid from dissolved phosphate rock; potash from kainit. Found: Phosphoric acid, soluble, 8.61; reverted, 2.72; insoluble, 0.38 ; total, 11.71 ; available, 11.33 ; potash, 1.83 ; chlorine, 3.6. 
4453 IARYLAND BONO SUPER-PIIOSPIIATE.. McFown \& Busey, Martinsburg. Guarantee-(As above). Found: Phosphoric acid, soluble, 1.38; reverted, 8.95; insoluble, 1.48, total, 11.71 ; available, 10.23 ; potash, 2.43 ; chlorine, 3.3.

4552 IARTLAND BONO SUPER-PIIOSPHATE.. J. L. Woodyard, Pruntytown. Guarantee-(As above). Found: Phosphoric acid, soluble, 4.71; reverted, 6.15; insoluble, 1.32 ; total, 12.18 ; a vailable, 10.86 ; potash, 2.06 ; chlorine, 2.6.

$4+18$ MARTLAND DISSOLVED S. C. BONE. J. L. Woodyard, Pruntytown. Guarantee-Phosphoric acid, soluble, 12; reverted, 2; insoluble, 1; total, 15; available, 14; phosphorie acid from dissolved phosphate rock. Found: Phosphoric acid, soluble, 13.62 ; reverted, 3.04 ; insoluble, 0.27 ; total, 16.93 ; available, 16.66 .

4421 MARTLAND DISSOLVED S. C. BONE. G. W. Harvey, Tumnelton. Guaranteo-(As above). Found: Phosphoric acid, soluble, 13.73 ; reverted, 3.12 ; insoluble, 0.31 ; totai, 17.16 ; available, 16.85 .

4452 MARYLAND DISSOLVED S. C. BONE. MCKown \& Busey, Martinsburg. Guarantee-(As above). Found: Soluble phosploric acid, 12.20; reverted, 4.15 ; insoluble, 0.52 ; total, 16,87 ; available, 16.35 .

4551 MARYLAND DISSOLVED'S. C. BONE. J. L. Woodyard, Pruntytown. Guarantee-(As above). Found: Soluble phosphoric acid, 10.84; reverted, 5.23; insoluble, 1.65; tota!, 17.72 ; available, 16.07 .

4574 SUSQUEHANNAH TYV PHOSPHATE. J. H. Miller \& Son, Martinsburg. Guarantee-Phosphoric acid, soluble, 6 ; reverted, 2 ; insoluble, 1 ; total, 9 ; available, 8 ; nitrogen, 0.82 ; potash, 1; phosphoric acid from dissolved phosphate rock and animal bone; nitrogen from dissolved fish and tankage; pot- 
ash from kainit. Found: Phosphoric acid, soluble, 4.91 ; reverted, 3.74; insoluble, 1.60; total, 10.25 ; available, 8.65 ; nitrogen, 0.96 ; potash, 1.28 ; chlorine, 4.2 ; availability of nitrogen, 85.

4575 SUSQUEHANNAH SUPERIOR ROCK PHOSPHATE. J. H. Miller \& Son, Martinsburg. Guarantee-Phosphoric acid, soluble, 12 ; reverted, 2 ; insoluble, 1 ; total, 15 ; available, 14; phosphoric acid from phosphate rock. Found: Phosphoric acid, soluble, 12.68; reverted, 3.42 ; insoluble, 1.36 ; total, 17.46 ; available, 16.10 .

4375 WILLIAMS \& CLARK'S ROYAL BONE PHOSPHATE. O. R. Carmen, Wellsburg. Guarantee-Phosphoric acid, soluble, 6 ; reverted, 2 ; insoluble, 1 ; total, 9 ; available, 8 ; nitrogen, 1.03 ; potash, 2 . Phosphoric acid from dissolved phosphate rock and animal bone; nitrogen from dissolved fish and tankage; potash from kainit. Found: Phosphoric acid, solnb!e, 6.73 ; reverted, 2.91 ; insoluble, 1.87 ; total, 11.51 ; available, 9.64 ; nitrogen, 1.04 ; potash, 2.46 ; chlorine, 1.1 ; availability of nitrogen, 77. Remark-Source of potash equivalent to muriate.

\section{WILLIAMS \& CLARK'S PROLIFIC CROP PRO.} DUCER. Lewisburg Milling \& Electric Company, Lewisburg. Guarantee-Phosphoric acid, soluble, 5 ; reverted, 2; insoluble, 1 ; total, 8 ; available, 7 ; nitrogen, 0.82 ; potash, 1 ; phosphoric acid from dissolved phosphate rock and animal bone; nitrogen from dissolved fish and tankage; potash from kainit. Found: Phosphoric acid, soluble, 1.60; reverted, 7.02 ; insoluble, 0.96 ; total, 9.58 ; available, 8.62 ; nitrogen, 1.04 ; potash, 1.10 ; chlorine, 5.5 ; availability of nitrogen, 79 . Remark-Chlorine excessive.

\section{WILLIAMS \& CLARK'S PROLIFIC CROP PRO-} DUCER. C. Philipps, Belington. Guarantee-Phosphoric acic, soluble, 5 ; reverted, 2 ; insoluble, 1 ; total, 8 ; available, 7 ; nitrogen, 0.82 ; potash, 1 ; phosphoric acid from dissolved phosphate rock and dissolved animal bone; nitrogen from dissolved fish anci 
tankage; potash from kainit. Found: Phcsphorie acid, soluble, 2.11 ; reverted, 6.65 ; insoluble, 1.04 ; total, 9.80 ; available, 8.76 ; potash, 1.31 ; chlorine, 2.9 ; availability of nitrogen, 88 .

4587 WILLIAMS of CLARK'S PROLIFIC CROP PR()DUCER. 1. G. Chrislip, Philippi. Guarantee-(As above). Found: Phosphorie acid, soluble, 5.00 ; reverted, 3.75 ; insoluble, 1.59 ; total, 10.34 ; available, 8.75 ; nitrogen, 1.07 ; potash, 1.30 ; cllorine, 4.1 ; availability of nitrogen, 75 .

4376 WILLIAMS \& CLARK'S GOOD GROWER POTATO PHOSPIIATE. Bishop \& Barbe, Jane Lew. GuaranteePhosphoric acid, soluble, 4; reverted, 2; insoluble, 1; total, 7 ; available, 6 ; nitrogen, 1.23 ; potash, 5 ; phosphorie acid from dissolved phosphate rock and animal bone; nitrogen from dissolver animal bone, fish and tankage; potash from kainit and manure salts. Found: Phosphorie aeid, soluble, 5.45; reverted, 2.61; insoluble, 1.16 ; total, 9.22 ; available, 8.06 ; nitrogen, 1.37 ; potash, 5.24 ; chloride, 1.1 ; availibility of nitrogen, 84 . Remark-Source of potash equivalent to mureati.

4420 WILLIAMS \& CLARK'S DISSOLVED BONE AND POTASII...G. W. Harvey, Tunnelton. Guarantee-Phosphoric acid, soluble, 8 ; reverted, 2 ; insoluble, 1 ; total, 11 ; available, 10 ; potash, 2; phosphoric acid from dissolved phosphate rock; potash from kainit. Found: Phosphoric aeid, soluble, 8.70; reverted, 2.56 ; insoluble, 0.42 ; total, 11.68 ; available, 11.26 ; potash, 1.91; chlorine, 2.9 .

4530. WILLIAMS . . CLARK'S DISSOLVED BONE AND POTASH. C. Philipps, Belington. Guarantee-(As above). Found:.. Phosphoric acid, soluble, 7.38 ; reverted, 3.36; insoluble, 0.97 ; total, 11.71 ; available, 10.74 ; potash, 1.86 ; chlorine, 3.1 .

4512 WILLIAMS d CLARK'S ACORN ACID PHOS. PHATE, Lewisburg Milling and Electric Company, Lewis- 
burg. Guarantee-Phosphoric acid, soluble, 12; reverted, 2; insoluble, 1; total, 15; available, 14; phosphoric acid from dissolved phosphate rock. Found: Phosphoric acid, soluble, 12.93; reverted, 4.06; insoluble, 0.27; total, 17.26; available, 16.99 .

4562 TILLIAMS \& CLARK'S ACORN ACID PHOSPHATE. A. G. Chrislip, Philippi. Guarantee-(As above). Found: Phosphoric acid, soluble, 12.47; reverted, 4.02; insoluble, 0.84 ; total, 17.33 ; available, 16.49 .

4410 ZELL'S SPECIAL COMPOUND FOR POTATOES AND VEGETABLES. Exchange Mill Company, Grafton. Guarantee-Phosphoric acid, soluble, 6; reverted, 2 ; insoluble, 1 ; total, 9 ; available, 8 ; nitrogen, 2.47 ; potash, 4 ; phosphoric acid from dissolved phosphate rock and animal bone; nitrogen from dissolved animal bone, blood and azotine; potash from muriate and manure salts. Found: Phosphoric acid, soluble, 5.81 ; reverted, 2.68; insoluble, 1.19; total, 9.68 ; available, 7.49 ; nitrogen, 2.35 ; potash, 4.60 ; chlorine, 1.4 ; availibility on nitrogen, 86 .

4550 ZELL'S AMMONIATED BONE SUPER-PHOSPHATE. Exchange Mill Company, Grafton. GuaranteePhosphoric acid, soluble, 6 ; reverted, 2; insoluble, 1; total, 9; available, 8 ; nitrogen, 1.65 ; potash, 2; phosphoric acid from dissolved phosphate rock and dissolved animal bone; nitrogen from dissolved animal bone, blood and azotine; potash from kainit. Found: Phosphoric acid, soluble, 3.45; reverted, 5.12; insoluble, 2.29 ; total, 10.86 ; available, 8.57 ; nitrogen, 1.82 ; potash, 2.13 ; chlorine, 2.9 ; availability of nitrogen, 90 .

4409 ZELL'S ECONOMIZER PHOSPHATE..Exchange Mill Co., Grafton. Guarantee-Phosphoric acid, soluble, 6; reverted, 2; insoluble, 1 ; total, 9 ; available, 8 ; nitrogen, 0.82 ; potash, 2; phosphoric acid from dissolved phosphate rock and 
dissolved animal bone; nitrogen from dissolved fish and tankage; potash from kainit. Found:. Phosphoric acid, soluble, 7.56; leverted, 2.39 ; insoluble, 1.82; total, 11.77 ; available, 9.95 ; nitrogen, 1.00 ; potash, 1.99 ; chlorine, 1.4 ; availability of nitrogen, S2.

4475 ZELL'S ECONOMIZER PHOSPHATE. J. L. Hall, Fairmont. Guarantee-(As above). Found: Phosphorie aeid, soluble, 3.35; reverted, 5.48; insoluble, 1.74; total, 10.67 ; available, 8.83 ; nitrogen, 1.10 ; potash, 2.31 ; ehlorine, 2.8 ; availability of nitrogen, 80 .

4548 ZELL'S ECONOMIZER PHOSPIIAT. Exchange Mill Co., Grafton. Guarantec-(As above). Found: Phosphoric acid, soluble, 4.32; reverted, 5.80; insoluble, 0.88; totai, 11.00 ; available, 10.12 ; nitrogen, 0.98 ; potash, 2.61; ehlorine, 1.9 ; availability of nitrogen, 85 .

4407 ZELL'S LITTLE .GIANT. Exchange Mill Co., Grafton. Guarantce-Phosphoric aeid, soluble, 5; reverted, 2; insoluble, 1 ; total, 8 ; available, 7 ; nitrogen, 0.82 ; potash, 1; phosphorie acid from dissolved plosphate roek and animal bone; nitrogen from dissolved fish and tankage; potash from kainit. Found: Phosphoric acid, soluble, 6.20 ; reverted, 2.84; insoluble, 1.46; total, 10.50; available, 9.04 ; nitrogen, 0.97 ; potash, 1.27 ; ehlorine, 2.8 ; availability of nitrogen, 89.

4473 ZELL'S LITTLE GIANT. J. L. Hall, Fairmont. Guarantee-(As above) Found: Phosphoric acid, soluble, 2.61 ; reverted, 5.77 ; insoluble, 1.37 ; total, 9.75 ; available, 8.38; nitrogen, 1.11; potash, 1.30 ; chlorine, 4.6 ; availability of nitrijgen, 80. Remark-Chlorine excessive.

4411 ZELL'S ELECTRIC PHOSPHATE. Exchange Mill Company, Grafton. Guarantec-Phosphorie acid, soluble, 8 ; reverted, 2; insoluble, 1 ; total, 11 ; available, 10 ; potash, 2; phosphoric acid from dissolved phosphoric rock; potash frouı 
kainit. Found: Phosphoric acid, soluble, 8.46; reverted, 3.00 ; insoluble, 0.46 ; total, 11.92 ; available, 11.46 ; potash, 2.14 ; chlorine, 2.5 .

4474 ZELL'S ELECTRIC PHOSPHATE. J. L. Hall, Fairmont. Guarantee-(As above). Found: Phosphoric acid, soluble, 6.79 ; reverted, 3.85 ; insoluble, 1.39 ; total, 12.03 ; available, 10.64; potash, 2.19 ; chlorine, 3.3.

4529 ZELL'S ELECTRIC PHOSPHATE. C. Philipps, Belington. Guarantee-(As above). Found: Phosphoric acil, soluble, 5.59 ; reverted, 4.77 ; insoluble, 1.45 ; total, 11.81 ; available, 10.36 ; potash, 2.06 ; chlorine, 3.6 .

4549 ZELL'S ELECTRIC PHOSPHATE. Exchange Mill Co., Grafton. Guarantee-(As above). Found: Phosphoric change Mill Co., Grafton. Guarantee-Phosphoric acid, soluble, phoric acid, soluble, 5.97; reverted, 5.27; insoluble, 0.91; total, 12.15; available, 11.24; potash, 1.95 ; chlorine, 2.9.

4408 ZELL'S DISSOLVED BONE PHOSPHATE. Exhcange Mill Co., Grafton. Guarantee-Phosphoric acid, soluble, 12 ; reverted, 2 ; insoluble, 1 ; total, 15 ; available, 14 ; phosphoric acid from dissolved phosphate rock. Found: Phosphoric acid, soluble, 13.69 ; reverted, 2.66 ; insoluble, 0.55 ; total, 16.90 ; availible, 16.35 .

4403 ZELL'S DISSOLVED BONE PHOSPHATE. त. T. Hodges, Shepherdstown. Guarantee-(As above). Found: Phosphoric acid, soluble, 13.60; reverted, 3.05; insoluble, 0.28 ; total, 16.93 ; available, 16.65 .

4476 ZELL'S DISSOLVED BONE PHOSPHATE. J. L. Hall, Fairmont. Guarantee-(As above). Found: Phosphoric acid, soluble, 12.63 ; reverted, 3.86 ; insoluble, 0.46 ; total, 16.95 ; available, 16.49 .

\section{ZELL'S DISSOLVED BONE PHOSPHATE.}


Johnson \& (iwinn, Alderson. Guarantee-(As above). Found: Phosphoric acid, soluble, 11.22; reverted, 4.3t; insoluble, 1.71; total, 17.27 ; available, 15.56 .

4527 ZELL'S DISSOLVED BONE PHOSPHATE. C. Philipps, Belington. Guarantce-(As above). Found: Phosphoric acid, soluble, 11.39 ; reverted, 5.92; insoluble, 1.66 ; total, 18.97 ; available, 17.31 .

4547 ZELL'S DISSOLIED BOYE PHOSPHATE. EXchange Mill Co., Grafton. Guarantec-(As above). Found: Phosphoric acid, soluble, 13.09 ; reverted, 3.5t; insoluble, 0.51; total, 17.14 ; available, 16.63 .

4617 ZELL'S DISSOLTED S. C. PHOSPHATE. R. Hunter, Berkeley Springs. Guarantee-Phosphoric acid ,soluble, 10 ; reverted, 2 ; insoluble, 1 ; total, 13 ; arailable, 12 ; phosphoric acid from dissolved phosphate rock. Found: Phosphoric acid, soluble, 8.09 ; reverted, 6.08 ; insoluble, 1.89 ; total, 16.06 ; available, 14.17 .

ABBOTT \& MARTIN RENDERING COMPANY.

\section{Columibus, Ohio.}

4634 IDEAL GRAIN GROTER. A. E. Huddleston, White Sulphur. Guarantec-Phosphoric acid, soluble, 4; reverted, 3 ; total, 9 ; available, 7 ; nitrogen, 0.82 ; potash, 1 ; phosphoric acid from dissolred bone phosphate; nitrogen from bone tankage, blood and tobacco stem; potash from muriate and to. bacco stems. Found: Phosphoric acid, soluble, 2.74; revertel, 5.98 ; insoluble, 1.85 ; total, 10.57 ; available, 8.72 ; nitrogen, 0.88 ; potash, 0.91 , and chlorine, 0.2 ; availability of nitrogen, 73 .

\section{ARMIOUR FERTILIZER WORKS.}

\section{B.LTIMIORE.}

4572 STAR PHOSPHATE. L. P. Licklider, Martinsbur: Guarantce-Phosphoric acid, soluble, 12; reverted, 2; insoluble, 
2 ; total, 16 ; available, 14 ; phosphoric aeid from sixper phosphate. Found: Phosphorie acid, soluble, 12.81 ; reverted, 1.55 ; insoluble, 0.26 ; total, 15.62 ; available, 14.36 .

4608 PHOSPHATE. W. N. Lemon, Shepherdstown. Guarantee-(As above). Found: Phosphorie acid, soluble, 13.60; reverted, 1.98; insoluble, 0.14; total, 15.7 ; availab?e, 15.58 .

4598 GRAIN GROWER. MIossman Brothers, Huntington. Guarantee-Phosphorie aeid, soluble, 6; reverted, 2 ; insoluble, 2 ; total, 10; available, 8 ; nitrogen, 1.65; potash, 2; phosphoric acid from animal bone and super-phosphate; nitrogen from bone, blood and tankage; potash from kainit, inuriate and sulphate. Found: Phosphoric acid, soluble, 4.34; reverted, 7.54; insoluble, 2.10; total, 13.98 ; available, 11.88; nitrogen, 1.76 ; potash, 2.13 ; chlorine, 1.4; availability of nitrogen, 85. Remart:Source of potaash equivalent to muriate.

\section{BAUGII \& SON'S COMPANY.}

\section{B.LTIMORE.}

4577 BAUGH'S CORN GROWER. W. N. Lemon, Shepherdstown. Guarantee-Phosphorie acid, insoluble, 3; total, 11; available, 8 ; nitrogen, 0.82 ; potash, 4 ; phosphoric aeid from animal bone and phosphate rock; nitrogen from animal bone and tankage; potash from kainit and muriate. Found: Phosphoric aeid, soluble, 5.21; reverted, 4.58; insoluble, 2.29; total, 12.08; available, 9.79 ; nitrogen, 0.82 ; potash, 5.47 ; chlorine, 1.4 ; availability of nitrogen, 73 .

4429 BAUGH'S SPECIAL POTATO MANURE. R. ?.. Lowndes, Clarksburg. Guarantee-Phosphorie aeid, insoluble, 2 ; total, 7; available, 5; nitrogen, 1.64; potash, 10 ; phosphoric acid from animal bone and phosphate rock; nitrogen from animal bone and tankage; potash from high grade sulphate, muri- 
ate and kainit. Found: Phosphoric acid, soluble, 4.43 ; reverted, 1.99 ; insoluble, 1.14 ; total, 7.56 ; available, 6.42 ; nitrogen, 1.78 ; potash, 10.22; chlorine, 0.7 ; availibility of nitrogen, 85 .

4430 BAUGH'S WARRANTED PURE BONE MEAL. R. T. Lowndes, Clarksburg. Guarantee-Total phosphorie aeid, 21.50; nitrogen, 3.49 ; plosphate acid from animal bones; nitrogen from animal bones. Found: Total phosphorie acid, 21.84; nitrogen, 3.96 ; availability of nitrogen, 81 .

$448 \pm$ BALGH'S WARRANTED PURE BONE UEAT. R. T. Lowndes, Clarksburg. Guarantec-(As above). Found: Total phosphoric acid, 23.56 ; nitrogen, 3.85 ; availability of nitrogen, 76 .

4568 BAUGH'S WARRANTED PURE BONE MEAL. J. H. Philipps' Sons, Berkeley Springs. Guarantee-(As above). Found-Total phosphoric acid, 21.57; nitrogen, 3.77; availabil. ity of nitrogen, 73.

4431 BAUGH'S DOUBLE EAGLE PHOSPHATE. T. T. Lowndes, Clarksburg. Guarantee-Phosphorie acid, insoluble, 3 ; total, 11 ; available, 8 ; nitrogen, 1.64 ; potash, 1 ; phosphoric acid from dissolved animal bone and phosphate rock; nitrogen fro manimal bones and tankage; potash from kainit. Found: Phospliorie acid, soluble, 5.53; reverted, 3.96 ; insoluble, 2.14; total, 11.63 ; arailable, 9.49 ; nitrogen, 1.96 ; potash, 1.30; ehlorine, 2.8 ; availability of nitrogen, 80 .

4460 BAUGH'S DOLBLE EAGLE PHOSPHATE. Henshaw \& Licklider, Martinshurg. Guarantec-(As above). Found: Phosphoric acid, soluble, 5.33; reverted, 3.70 ; insoluble, 2.05; total, 11.0S; available, 9.03 ; nitrogen, 1.88; potash, 2.17 ; chlorine, 26 ; availability of nitrogen, 81 .

4481 BACGH'S DOUBLE EAGLE PHOSPHATE. R. T. Lowndes, Clarksburg. Guarantee-(As above). Found: Phosphoric acid, soluble, 5.21; reverted, 2.86; insoluble, 2.84; total, 2.17 ; chlorine, 2.6 ; availability of nitrogen, 81 . 
4567 BAUGH'S DOUBLE EAGLE PHOSPHATE. J. H. Philipps' Sons, Berkeley Springs. Guarantee-(Ảs above). Found: Phosphoric acid, soluble, 3.38; reverted, 5.32 ; insoluble, 2.35; total, 11.05; available, 8.70 ; nitrogen, 1.76 ; potash, 1.57; chlorine, 2.4 ; availability of nitrogen, 87. Remark-Nitrale of soda found, but not guaranteed.

4542 BAUGH'S DOUBLE EAGLE PHOSPHATE. O‡futt \& Lakin, Terra Alta. Guarantee-(As above). Found: Phosphoric acid, soluble, 3.26; reverted, 5.32 ; insoluble, 2.43; total, 11.01 ; available, 8.68 ; nitrogen, 1.64 ; potash, 1.39 ; chlorine, 2.6; availability of nitrogen, 91 . Remark-Nitrate of sod:t found, though not guaranteed.

4428 BAUGH'S GENERAL CROP GROWER. R. 'T. Lowndes, Clarksburg. Guarantee-Phosphoric acid, insoluble, 1 ; total, 9 ; available, 8 ; nitrogen, 0.82 ; potash, 1 ; phosphoric acid from animal bone and phosphate rock; nitrogen from tankage and animal bone; potash from kainit. Found: Phosphoric acid, soluble, 6.19 ; reverted, 2.86 ; insoluble, 1.84 ; total, 10.89 ; available, 9.05 ; nitrogen, 1.52 ; potash, 1.65 ; chlorine, 2.6 ; availability of nitrogen, 66. Remark-Availability of nitrogenous material low.

4459 BAUGH'S GENERAL CROP GROWER. Henshaw and Licklider, Martinsburg. Guarantee-(As above). Found: Phosphoric acid, soluble, 6.51; reverted, 2.24; insoluble, 1.57; total, 10.32 ; available, 8.75 ; nitrogen, 1.03 ; potash, 1.48 ; chlorine, 5.1 ; availability of nitrogen, 66 . Remark-Chlorine excessive.. Availability of nitrogenous material low.

4482 BAUGH'S GENERAL CROP GROWER. R. T. Lowndes, Clarksburg. Guarantee-(As above). Found: Phoñphoric acid, soluble, 5.39; reverted, 2.85 ; insoluble, 2.66 ; total, 10.90 ; available, 8.24 ; nitrogen, 1.32 ; potash, 1.24 ; chlorine, 4.6 ; availability of nitrogen, 60. Remark-Chlorine excessive. Availability of nitrogenous material low. 
4578 BAUGH'S GENERAL CROP GROTER. W. N. Lemon, Shepherdstown. Guarantee-(As above). Found: Phosphoric acid, soluble, 6.45; reverted, 1.75; insoluble, 1.87; total, 10.07 ; a vailable, 8.20 ; nitrogen, 0.94 ; potash, 1.53 ; chlor. ine, 4.3 ; availability of nitrogen, 80 .

4483 BAUGH'S WHEAT FERTILIZER.. R. T. Lowndes, Clarksburg. Guarantee-Phosphoric acid, insoluble, 3; total, 11 ; available, 8 ; nitrogen, 1.64: potash, 2 : phosphoric acid from animal bones and phosphate rock; nitrogen from animai bone and tankage; potash from kainit and muriate. Found: Phosphoric acid, soluble, 5.35; reverted, 3.23; insoluble, 2.58; total, 11.16; available, 8.58; nitrogen, 1.93; potasin, 2 ; chlorine, 32; availability of nitrogen, 84. Remark-Source of potasin equivalent to kainit.

4513 BAUGH'S HIGH GRADE ACID PHOSPHATE. I. W. Conway, Laurel Point; sent in by Josephus Jones. Gua:antee-Phosphoric acid, available, 14; phosphoric acid from phosphate rock. Found: Phosphoric acid, soluble, 12.41; reverted, 3.30 ; insoluble, 1.85 ; total, 17.56 ; available, 15.71.

4570 BAUGH'S HIGH GRADE ACID PHOSPHATE: A. R. Unger, Berkeley Springs. Guarantee-(As above). Found: Phosphoric acid, soluble, 8.70 ; reverted, 7.71 ; insoluble, 3.47 ; total, 19.88; available, 16.41.

4579 BAUGH'S HIGH GRADE ACID PHOSPHATE. W. N. Lemon, Shepherdstown. Guarantee-(As above). Found: Phosphoric acid, soluble, 2.83; reverted, 15.60; insoluble, 1.39; total, 19.82; available, 18.43.

BOWKER FERTILIZER COMPANY.

Boston, Mass.

4386 BOTKER'S HARTEST BONE. Drummond \& Company, Buckhannon. Guarantee-Phosphoric acid, total, 10; 
available, 8 ; nitrogen, 0.75 ; potash, 1 ; phosphoric acid from dissolved animal bone and dissolved mineral phosphate; nitrogen from dissolved bone and tankage; potash from kainit and mu!iate. Found: Phosphoric acid, soluble, 3.03 ; reverted, 8.00 ; insoluble, 3.85 ; total, 14.88 ; available, 11.03 ; nitrogen, 0.90 ; potash, 1.87 ; chlorine, 1.6 ; availability of nitrogen, 78 .

4504 BOWKER'S HARVEST BONE. J. M. Miller \& Brother, Ronceverte. Guarantee-(As above). Found: Phosphoric acid, soluble, 0.82 ; reverted, 7.62 ; insoluble, 3.98 ; total, 12.42 ; available, 8.44 ; nitrogen, 0.83 ; potash, 1.26 ; chlorine, 1.7 ; availability of nitrogen, 75 .

4520 BOWKER'S HARVEST BONE. Payne Brothers, Seebert. Guarantee-(As above). Found: Phosphoric acill, soluble, 1.52 ; reverted, 7.52 ; insoluble, 3.70 ; total, 12.74 ; available, 9.04 ; nitrogen, 0.91 ; potash, 1.26 ; chlorine, 2.3 ; availability of nitrogen, 82 .

4385 BOWKER'S DISSOLVED BONE. Drummond \& Company, Buckhannon. Guarantee-Total phosphoric acid, 11; available, 10 ; phosphoric acid from dissolved mineral phosphate. Found: Phosphoric acid, soluble, 1.57; reverted, 9.78; insoluble, 2.35 ; total, 13.60 ; available, 11.25 .

4503 BOWKER'S DISSOLVED BONE. J. M. Miller \& Brother, Ronceverte. Guarantee-(As above). Found: Phosphoric acid, soluble, 0.99 ; reverted, 9.73 ; insoluble, 3.84 ; total, 14.56 ; available, 10.72 .

4384 BOWKER'S DISSOLVED BONE WITH POTASIC Drummond \& Company, Buckhannon. Guarantee-Phosphoric acid, total, 11; available, 10; potash, 1; phosphoric acid from dissolved mineral phosphates; potash from kainit and muriate. Found: Phosphoric acid, soluble, 2.11; reverted, 8.75; insolı. ble, 2.21; total, 13.07 ; available, 10.86; potash, 1.07 ; chlorine, 2.4 . 
4388 BOWKER'S DISSOLVED BONE WITH POTASII Mason \& Watson, Kingwood. Guarantee-(As above). Found: Phosphoric acid, soluble, 1.45; reverted, 9.15 ; insoluble, 2.28; total, 12.88; available, 10.70 ; potash, 1.05 ; chlorine, 1.9.

\section{BOWKER'S DISSOLVED BONE WITH POTASI} J. M. Miller \& Brother, Roneeverte. Guarantee-(As above). Found: Phosphorie acid, soluble, 0.82 ; reverted, 9.40 ; insoluble, 3.67 ; total, 13.89 ; available, 10.22 ; potash, 1.20 ; ehlorine, 1.7.

4521 BOWKER'S DISSOLVED BONE WITH POTASH Payne Brothers, Seebert. Guarantec-(As above). Found: Phosphorie acid, soluble, 0.99; reverted, 9.99 ; inscluble, 2.47; total, 13.45 ; available, 10.98 ; potash, 1.07 ; chlorine, 2.9 . Remark-Source of potash equivalent to kainit.

4387 BOWKER'S SOLUBLE BONE. Mason \& Watson, Kingwood. Guarantee-Phosphorie acid, total, 15; available, 14; phosphoric aeid from dissolved mineral phosphates. Found: Phosphoric acid, soluble, 9.52; reverted, 5.04; insoluble, 3.61; total, 18.17; available, 14.56 .

4643 BOWKER'S BONE MEAL. A. E. Huddleston. White Sulphur. Guarantee-Phosphoric acid, total, 20; nitrugen, 1.50; phosphoric acid from ground animal bone; nitrogen from ground animal bone. Found: Total phosphoric aeid, 22.41 ; nitrogen, 1.91 ; availability of nitrogen, 90 .

\section{THE CINCINNATI PHOSPHATE COMPANY.}

Cincinnati, Ohio.

4599 CAPITOL WIIEAT GROTER. Williamson \& Varner, St. Marys. Guarantee-Plosphoric acid, soluble, 12; reverted, 2 ; insoluble, 1 ; total, 15 ; available, 14 ; phosphorie acia from mineral phosphate: Found: Phosphorie acid, solnble, 30 ; reverted, 4.95; insoluble, 4.29 ; total, 18.54 ; available, 14.25 .

4593 CAPITOL GRAIN AND GRASS GROWER. 
Shanklin Brothers, Lowell. Guarantee-Phosphoric acid, soluble, 8 ; reverted, 2 ; insoluble, 1 ; total, 11 ; available, 10 ; nitrogen, 0.80 ; potash, 1 ; phosphoric acid from animal tankage bone and mineral phosphates; nitrogen from animal tankage; potasin from muriate. Found: Phosphoric acid, soluble, 7.75; reverted, 5.36 ; insoluble, 1.24 ; total, 14.35 ; available, 13.12 ; nitrogen, 0.91 ; potash, 1.58; chlorine, 1.5; availability of nitrogen, 78 .

4594 CAPITOL SUPER-PHOSPHATE. Shanklin Brothers, Lowell. Guarantee-Phosphoric acid, soluble, 10; reverted, 2 ; insoluble, 1; total, 13; available, 12; phosphoric acid Irom mineral phosphate. Found: Phosphoric acid, solublr, 9.94; reverted, 5.11 ; insoluble, 1.13 ; total, 16.18 ; available, 15.05 .

\section{JARECHI CHEMICAL COMPANY.}

\section{Sanduskr, Оніо.}

4336 NUMBER ONE FISH GUANO. W. F. Sill, Pennצboro. Guarantee-Phosphoric acid, soluble, 8 ; reverted, 2 ; insoluble, 1 ; total, 11 ; available, 10 ; nitrogen, 0.86 ; potash, 1 ; phosphoric acid from bone black, phosphate and fish tankage; nitrogen from fish and animal tankage; potash from muriate. Found: Phosphoric acid, soluble, 8; reverted, 3.61; insoluble, 1.68 ; total, 13.29 ; available, 11.61 ; nitrogen, 0.79 ; potash, 1.26 ; chlorine, 1.7; availability of nitrogen, 78. Remark-Source of potash from low grade muriate.

4500 NUMBER ONE FISH GUANO. J. S. Burdette, Alderson. Guarantee-(As above). Found: Phosphoric acil, soluble, 6.64 ; reverted, 5.28 ; insoluble, 1.28 ; total, 13.20 ; available, 11.92 ; nitrogen, 0.83 ; potash, 1.34 ; chlorine, 1.00 ; availability of nitrogen, 80 .

4559 NUMBER ONE FISII GUANO. J. M. Hagerty, Farmington. Guarantee-(As above). Found: Phosphoric acid, soluble, 7.57 ; reverted, 3.77 ; insoluble, 2.94 ; total, 14.28 ; availia- 
ble, 11.34 : nitrogen, 0.81 ; potash, 1.19 ; ehlorine, 0.2 ; availability of nitrogen, 83 .

4366 C. O. D. РНOSPHATE. W. S. Stont, Harrisville. Guarantec-Phosphorie aeid, soluble, 11 ; reverted, 3 ; insoluble, 1 ; total, 15; available, 14; phosphoric aeid from mineral phosphate. Found: phosphoric acid, soluble, 10.38; reverted, 3.69 ; insoluble, 2 ; total, 16.07 ; available, 14.07 .

4435 C. O. D. PHOSPHATE. O. P. Cox \& Son, Toll Gate. Guarantee-(As above). Found: Phosphorie acid, soluble, 9.91; reverted, 5.26 ; insoluble, 1.45 ; total, 16.62 ; available, 15.17 .

4497 C. O. D. PIIOSPHATE. J. S. Burdette, Alderson. Guarantee-(As above). Found: Phosphorie aeid, solublr, 8.16 ; reverted, 5.90; insoluble, 2.69 ; total, 16.75 ; available, 14.06 .

4560 C. O. D. PHOSPHATE. J. II. Hagerty, Farmington. Guarantee-(As above). Found: Phosphoric acid, soluble, 9.03 ; reverted, 5.18; insoluble, 3.15 ; total, 17.36 ; available. 14.21 .

4364 GROUND BONE. W. S .Stout, Marrisville. Guarantec-Phosphorie acid, total, 20; nitrogen, 2.50; phosphoric aeid from bone; nitrogen from bone. Found: Phosphorie acid, total, 24.97 ; nitrogen, 2.85 ; availability of nitrogen, 81 .

4499 GROUND BONE. J. S. Burdette, Alderson. Guarantee-(As above). Found: Phosphoric acid, total, 20.05; nitrogen, 2.15 ; availability of nitrogen, 87 .

4498 DISSOLVED BONE WITH POTASH. J. S. Burdette, Alderson. Guarantee-Phosphoric acid, soluble, 10 ; r.3verted, 2; insoluble, 1 ; total, 13 ; available, 12 ; potash 3 ; phosphoric acid from mineral phosphates with bone; potash from carbonate and muriate. Found: Phosphorie acid, soluble, 7.87; reverted, 5.14 ; insoluble, 4.25 ; total, 17.26 ; available, 13.01 ; potash, 1.76 ; chlorine, 0.2 . 
4363 FISH AND POTASH POTATO AND TOBACCO FOOD. W. S. Stout, Harrisville. Guarantee-Phosphoric acid, soluble, 6 ; reverted, 2 ; insoluble, 1 ; total, 9 ; available, 8 ; nitrogen, 0.86 ; potash, 4 ; phosphoric acid from bone black, mineral phosphates, fish and animal tankage; nitrogen from fish tankage and animal tankage; potash from carbonate and muriate. Found: Phosphoric acid, soluble, 5.10; reverted, 4.93; insoluble, 1.77; total, 11.80 ; available, 10.13 ; nitrogen, 0.98 ; potash, 3.81 ; chlorine, 0.4 ; availability of nitrogen, 82 .

4369 FISH AND POTASH, POTATO AND TOBACCO FOOD. W. F. Sill, Pennsboro. Guarantee-(As above). Found: Phosphoric acid, soluble, 6.69; reverted, 3.53; insoluble, 1.59; total, 11.71 ; available, 10.12 ; nitrogen, 0.85 ; potash, 3.56 ; chlorine, 0.4 ; availability of nitrogen, 80 .

4496 FISH AND POTASH, POTATO AND TOBACCO FOOD. H. C. Bare Hardware Company, Alderson. Guarantee(As above). Found; Phosphoric acid, soluole, 4.64; reverted, 5.72 ; insoluble, 1.28 ; total, 11.64; available, 10.36 ; nitrogen, 1.07 ; potash, 3.61 ; chlorine, 0.5 ; availability of nitrogen, 82.

4368 ST. BERNARD PHOSPHATE. W. F. Sill, Pennsboro. Guarantee-Phosphoric acid, soluble, 10 ; reverted, 2; insoluble, 1 ; total, 13 ; available, 12 ; phosphoric acid from mineral phosphate. Found: Phosphoric acid, soluble, 10.06 ; reverted, 3.54 ; insoluble, 1.59 ; total, 15.19 ; available, 13.60 .

4494 ST. BERNARD PHOSPHATE. H. C. Bare Hardware Company, Alderson. Guarantee-(As above). Found: Phosphoric acid, soluble, 6.69; reverted, 6.85; insoluble, 1.94; total, 15.48; available, 13.54 .

4495 PHOSPHATE AND POTASH. H. C. Bare Hardware Company, Alderson. Guarantee-Phosphoric acid, soluble, 8; reverted, 2 ; insoluble, 1 ; total, 11 ; available, 10 ; potash, 2 ; phosphoric acid from mineral phosphates; potash from muri- 
ate. Found. Phosphorie aeid, soluble, 2.34; reverted, 6.60 ; insoluble, 1.96 ; total, 10.90 ; available, 8.91 ; potash, 2.13 ; chlorin:, 1.0 .

4502 PHOSPHATE AND POTASH. J. S. Burdette, Ronceverte. Guarantec-(As above). Found: Phosphoric acid, soluble, 5.05; reverted, 6.99 ; insoluble, 1.87; total, 13.91 ; availible, 12.04 ; potash, 1.47 ; chlorine, 0.8 .

4558 PHOSPHATE AND POTASH. J. M. Hagerty, Farmington. Guarantec-(As above). Found: Phosphorie acid, soluble, 5.73; reverted, 5.41 ; insoluble, 3.93 ; total, 15.07 ; available, 11.14 ; potash, 1.57 ; ehlorine, 0.1 .

4501 "SQUARE" BRAND PHOSPHATE AND POTASII. J. S. Burdette, Alderson. Remark-No brand bcaring preciscly this name was registercd. Found: Phosphoric acil, soluble, 6.98 ; reverted, 4.82 ; insoluble, 3.40 ; total, 15.20 ; available, 11.80 ; potash, 1.83 ; ehlorine, 0.2 .

\section{MARIETTA BONE \& PHOSPHATE COMPANY.}

\section{Marietta, Оhio.}

4362 "HORSE" BRAND POTATO AND TRUCK SPECIAL. C. H. Becker, Wheeling. Guarantee-Phosphoric acid, scluble, 5 ; reverted, 3 ; insoluble, 1 ; total, 9 ; available, 8 ; nitrogen, 3 ; potash, 5.50; phosphoric acid from bone and acid phosphate; nitrogen from bone, flesh, blood and nitrate of soda; potash from sulphate muriate and kainit. Found: Phosphoric acid, soluble, 0.95; reverted, 4.79; insoluble, 1.24; total, 6.98; available, 5.74 ; nitrogen, 2.78 ; potash, 4.32 ; chlorine, 1.2 ; availability of nitrogen, 91. Remark-Source of potash equivalent to muriate.

LLLL

4647 "HORSE" BRAND ACID PHOSPHATE. R. A. Johnson, Parkersburg. Guarantee-Phosphorie acid, insoluble, 2; total, 11; available, 12; plosphoric acid from S. C. rock. 
Found: Phosphorie acid, soluble, 0.96 ; reverted, 11.88 ; insoluble, 2.64; total, 15.48; available, 12.84 .

\section{G. OBER \& SONS' COMPANY.}

B.LLTimore, MD.

4389 OBER'S FARMERS STANDARD AMMONIATED PHOSPHATE. J. M. Graham, Kingwood. Guarantee-Phosphoric acid, soluble, 7 ; reverted, 2 ; insoluble, 2 ; toral, 11 ; available, 9 ; nitrogen, 1.64; potash, 2; phosphoric acid from high grade Florida phosphate, bone tankage and fish; nitrogen from high grade bone and blood tankage, and fish; potash from sulphate of potash. Found: Phosphorie acid, soluble, 8.96; reverted, 2.11; insoluble, 1.39 ; total, 12.36; available, 10.97 ; nitrogen, 1.83 ; potash, 2.20 ; ehlorine, 2.6 ; availability of nitrogen, 86. Remark-Source of potash not as guaranteed; is equivalent to kainit.

4471 OBER'S FARMERS STANDARD AMMONIATED PHOSPHATE. Cast and Holden, Clarksburg. Guarantee(As above). Found: Phosphoric acid, soluble, 8.72; reverted, 2.02 ; insoluble, 1.14; total, 11.88; available, 10.74; nitrogers, 1.69 ; potash, 2.29 ; chlorine, 2.8 ; availability of ritrogen, 83. Remark-Source of potash equivalent to kainit.

4592 OHI OFARMERS' STANDARD AMMONIATE! PHOSPHATE. A. G. Chrislip, Philippi. Guarantee-(As above). Found: Phosphoric acid, soluble, 9.20; reverted, 2.21 ; insoluble, 1.84; total, 13.25 ; available, 11.41 ; nitrogen, 1.95 ; potash, 2.36 ; chlorine, 2.4 ; availability of nitrogen, 87 . RemarkSource of potash equivalent to kainit.

4390 OBER'S FARMERS MIXTURE. J. M. Graham, Kingwood. Guarantee-Phosphoric acid, soluble, 7; reverted, 2 ; insoluble, 2 ; total, 11 ; available, 9 ; nitrogen, 0.82 ; potash, :2; phosphoric acid from high grade Florida phosphate, bone tankage and fish; nitrogen from high grade bone, blood tankage and 
fish; potash from sulphate of potash. Found: Plosphoric aeid, soluble, 8.90 ; reverted. 2.04 ; insoluble, 1.52 ; total, 12.46 ; available. 10.94 ; nitrogen, 0.90 ; potash, 2.53; chlorine, 1.1 ; a vailability of nitrogen, 75. Remark-Source of potash equivalent to muri. ate.

44T2 OBER'S FARMERS MITTURE. Cast and Holden, Clarksburg. Guuruntee-(As above). Found: Phosphorie aeid, soluble, 8 ; reverted, 2.57 ; insoluble, 1.92 ; total, 12.49 ; available, 10.57 : nitrogen, 1.19 : potash, 2.80 ; chlorine, 0.9 ; availability of of nitrogen, S8. Remarl-Source of potash equivalent to muriute.

4HTT OBER'S FARMERS MIXTURE. J. J. Chisler, Faimont. Guaruntce-(As above). Found: Phosphoric aeinl, soluble, 8.29 ; reverted, 2.52 ; insoluble, 1.82 ; total, 12.63 ; available, 10.81 ; nitrogen, 1.17 ; potash, 2.73 ; chlorine, 0.9 ; availability of nitrogen, S2. Remark-Source of potash equivalent to muriate.

4590 OBER'S FARIERS MITURE. A. G. Chrislip, Philippi. Guaruntec-(As above). Found: Phosphoric aeid, soluble, S.17 ; reverted, 3.26 ; insoluble, 2.57 ; total, 14.00 ; available, 11.t3; nitrogen, 1.14; potash, 2.27; elılorine, 2.1; availability of nitrogen, 86. Remark-Source of potash equivalent to low grade muriate.

4393 OBER'S DISSOLVED BONE PHOSPHATE AND POTASH. J. H. Graham, Kingwood. Guarantee-Phosphoric acicl, soluble, 9 ; reverted, 2 ; insoluble, 2 ; total, 13 ; available, 11 ; potash, 2; phosphoric aeid from high grade Florida phosphate; potash from sulphate and muriate. Found: Phosphoric acid, soluble, 10.73; reverted, 1.33 ; insoluble, 0.77 ; total, 12.83 : available, 12.06: potash, 3.25; chlorine, 1.1. Remark-Source of potash cquivalent to muriate.

4591 OBER'S DISSOLVED BONE PHOSPHATE AND 
POTASH. A. G. Chrislip, Philippi. Guarantee-(As above). Found: Phosphoric aeid, soluble, 9.90; reverted, 3.10 ; insoluble, 3.06 ; total, 16.06; available, 13.00; potash, 2.01 ; chlorine, 2.1. Remark-Source of potash equivalent to low grade muriate.

4618 OBER'S DISSOLVED BONE PHOSPHATE AND POTASH. G. B. Roby, Keyser. Guarantee-(As above). Found: Phosphoric aeid, soluble, 8.78; reverted, 3.84; insoluble, 3.08; total, 15.70 ; available, 12.62; potash, 1.98; chlorine, 1.2. Remark-Source of potash equivalent to muriate.

4391 OBER'S DISSOLVED BONE PHOSPHATE. J. M. Graham, Kingwood. Guarantee-Phosphorie aeid, soluble, 11 ; reverted, 3 ; insoluble, 2 ; total, 16; available, 14; phosphorie aeid from high grade Florida phosphate. Found: Phosphoric acid, soluble, 12.65; reverted, 1.87; insoluble, 1.02 ; total, 15.54; available, 14.52 .

4580 OBER'S DISSOLVED BONE PHOSPHATE. Seneindiver \& Stewart, Martinsburg. Guarantee-(As above). Found: Phosphorie acid, soluble, 13.24; reverted, 4.25; insoluble, 0.75 ; total, 18.24 ; available, 17.49 .

4619 OBER'S DISSOLVED BONE PHOSPHATE. G. B. Roby, Keyser. Guarantee-(As above). Found: Phosphorie aeid, soluble, 15.17 ; reverted, 2.60 ; insoluble, 0.58 ; total, 18.35; available, 17.77.

4526 OBER'S HIGH GRADE ACID PHOSPHATE. Sent in for analysis by J. B. Huyett, Wheatland. Guarantee--Phosphoric acid, soluble, 14.50; reverted, 1.50 ; insoluble, 1 ; total, 17; available, 16; phosphoric acid from high grade Florida phosphate. Found: Phosphorie acid, soluble, 15.61; revertec, 1.84; insoluble, 0.27 ; total, 17.72 ; available, 17.45 .

4581 S. \& S, SPECIAL WHEAT COUPOUND. Sencin- 
diver \& Stewart, Martinsburg. Guarantec-Phosphoric acid, soluble, 7 ; reverted, 2 ; insoluble, 2 ; total, 11 ; available, 9 ; nitrogen, 0.82 ; potash, 2; phosphorie aeid from high grade Florida plosphate, bone tankage, and fish; potash from sulphate of potash; nitrogen from high grade bone, blood tankage, and fish. Found: Phosphoric acid, soluble, 7.84; reverted, 2.62; insoluble, 2.70 ; total, 13.16 ; available, 10.46 ; nitrogen, 1.04 ; póash, 2.11; chlorine, 2.00 ; availability of nitrogen, 88 . RemarkSource of potash equivalent to low grade muriate.

\section{OHIO FARIIERS FERTILIZER COMPANY.}

Columbes, Оhio.

4426 CORN, OATS AND WHEAT, FISH GUANO. Ha?ry Johnson, Clarksburg. Guarantee-Phosphoric acid, soluble, 5 ; reverted, 3 ; total, 10 ; available, 8; nitrogen, 1.23; potash, 2 ; phosphoric acid from dissolved bone phosphate; nitrogen, two-eights from blood; two-eights from fish scraip; three-eights from bone tankage; one-eight from tobreeo stems; potash, onefourth from tobaceo stems: three-fourths from muriate. Found: Phosphoric aeid, soluble, 5.18; reverted, 4.21; insoluble, 1.24; total, 10.63 ; available, 9.39 ; nitrogen, 1.37 ; potash, 1.91 ; chlorine, 1.00 ; availability of nitrogen, 79 .

4642 CORN, OATS AND THEAT FISH GUANO. Speneer Milling Company, Spencer. Guarantee-(As above). Found: Phosphoric acid, soluble, 2.07; reverted, 7.09; insolu. ble, 2.55; total, 11.71 ; available, 9.16 ; nitrogen, 1.23 ; potas!, 2.53 ; chlorine, 0.8 ; availability of nitrogen, 86 .

4427 GENERAL CROP FISH GUANO. Harry Johnson, Clarksburg. Guarantec-Phosphoric acid, soluble, 4; reverted, 3 ; total, 9 ; available, 7 ; nitrogen, 0.82 ; potash, 1 ; phosphoric acid from dissolved bone phosphate; nitrogen, twoeights from blood; two-eights from fish scrap; three-eights from bone tankage; one-eight from tobaceo stems; potash, one-fourth 
from tobacco stems; three fourths from muriate. Found: Phosphoric acid, soluble, 2.60; reverted, 5.78; insoluble, 1.29; total, 9.67; available, 8.38 ; nitrogen, 1.03 ; potash, 0.91 ; chlorine, 1.5 ; availability of nitrogen, 78. Remark-Source of potash equivaient to low grade muriate.

4641 GENERAL CROP FISH GUANO. Spencer Milling Company, Spencer. Guarantee-(As above). Found: Phosphoric acid, soluble, 1.85; reverted, 5.90; insoluble, 2.70; total, 10.45; available, 7.75 ; nitrogen, 1.08 ; potash, 1.24 ; chlorine, 0.2 ; availability of nitrogen, 77 .

4554 WHEAT MAKER AND SEEDING DOWN. W. H. Bailey, Morgantown. Guarantee-Phosphoric acid, soluble, 5 ; reverted, 3 ; total, 10 ; available, 8; nitrogen, 0.41 ; potash, 2.50 ; phosphoric acid from dissolved bone phosphate; nitrogen, two-eights from blood; five-eights from bone tankage; one-eight from tobacco stems; potash, one-fourth from tobaceo stems; three-fourths from muriate. Found: Phosphoric acid, soluble, 2.99 ; reverted, 5.51 ; insoluble, 1.89 ; total, 10.39 ; available, 8.50 ; nitrogen, 0.67 ; potash, 2.83 ; chlorine, 1.6 ; availability of nitrngen, 78. Remark-Source of potash equivalent to low grade muriate.

4425 ACID PHOSPHATE. Harry Johnson, Clarksburg. Guarantee-Phosphoric acid, total, 10; available, 9; phosphoric acid from phosphate rock. Found: Phosphoric acid, soluble, 8.62 ; reverted, 6.36 ; insoluble, 1.32 ; total, 16.30 ; available, $14.9 \mathrm{~S}$.

4555 SOLUBLE BONE AND POTASH. W. H. Bailey, Morgantown. Guarantee-Phosphoric acid, soluble, 5 ; reverted, 3; total, 9; available, 8; potash, 2; phosphoric acid from phosphate rock; potash from muriate. Found: Phosphoric acid, soluble, 1.36 ; reverted, 9.67 ; insoluble, 1.20 ; total, 12.23 ; available, 11.03; potash, 2.25 ; chlorine, 0.8 .

4640 SOLUBLE BONE AND POTASH. Spencer Milling Company, Spencer. Guarantee-(As above). Found: 
Phosphoric acid, soluble, 0.97 ; reverted, 8.55 ; insoluble, 3.54; total, 13.06 ; available, 9.52 ; potash, 2.01 ; chlorine, 1.0 .

\section{PIEDMONT MIT. AIRY GUANO COMPANY.}

Baltimore, Mid.

\section{PIEDHONT PURE RAW BONE MITURE.} James Hawker, Mamnington. Guarantee-Phosphoric acid, insoluble, 4: total, 12; available, 8; nitrogen, 1.02; potash, 1.50; phosphorie aeid from bone tankage; nitrogen from bone tankage; potash from muriate and kainit. Found: Phosphorie acid, soluble, 1.48; reverted, 6.81 ; insoluble, 3.94 ; total, 12.23 ; available, 8.29; nitrogen, 1.07 ; potasl, 1.68 ; chlorine, 2.8 ; availability of nitrogen, 64. Remark-Source of potash equivalent to kainit. Availability of nitrogen low.

\section{PIEDMONT FARUERS HIGII GRADE BONE'} AND POTASII. James Hawker, Mammington. GuarantecPhosphorie acid, insoluble, 2; total, 12; available, 10; potash, 2 ; phosphorie aeid from S. C. roek; potash from kainit. Found: Phosphoric acid, soluble, 4.38; reverted, 6.08; insoluble, 1.45; total, 11.91 ; available, 10.46 ; potash, 2.34 ; ehlorine, 3.2 .

\section{R. H. POLLOCK.}

Baltimore, Mp.

4535 POLLOCK'S DISSOLVED S. C. BONE. Washington \& Alexander, Charles Town. Guarantee-Phosphoric acil, insoluble, 1 ; total, 15 ; available, 14 ; phosphorie aeid from S. U. rock. Found: Phosphorie aeid, soluble, 2.06 ; reverted, 9.21 ; insoluble, 1.52; total, 12.79 ; available, 11.27.

4536 POLLOCK'S VICTOR BONE PHOSPHATE. Washington \& Alexander, Charles Town. Guarantee-Phos. phorie aeid, insoluble, 1 ; total, 10 ; available, 9 ; potash, 1 ; phosphorie acid from S. C. rock; potash from kainit. Found: Phos- 
phoric acid, soluble, 8.02 ; reverted, 5.86 ; insoluble, 3.47 ; total, 17.35 ; available, 13.88 ; potash, 0.60 ; chlorine, 3.1 .

\section{POWHATAN CHEMICAL COMPANY.}

Richmond, Virginia.

4515 MAGIC WHEAT GROWER. Lewisburg Milling \& Electric Company, Lewisburg. Guarantee-Phosphoric acic!, soluble, 5 ; reverted, 3 ; insoluble, 1 ; total, 9 ; available, 8 ; nitrigen, 0.82 ; potash, 2 ; phosphoric acid from mineral phosphate and tankage; nitrogen from tankage, blood and nitrate of soda; potash from muriate. Found: Phosphoric acid, soluble, 3.19; reverted, 6.38 ; insoluble, 1.33 ; 'total, 10.90 ; available, 9.57 ; nitrogen, 0.82 ; potash, 1.55 ; chlorine, 1.1 ; availability of nitrogen, 86.

4516 BONE AND POTASH MIXTURE. Lewisburg Milling and Electric Co., Lewisburg. Guarantee-Phosphoric acid, soluble, 7 ; reverted, 3 ; insoluble, 1 ; total, 11 ; available, 10 ; potash, 2 ; phosphoric acid from mineral phosphate; potash from sulphate of potash. Found: Phosphoric acid, soluble, 3.72 ; reverted, 7.23 ; insoluble, 1.96 ; total, 12.91 ; available, 10.95; potash, 2.20; chlorine, 0.9. Remark-Source of potash equivalent to muriate; sulphate guaranteed.

4517 HIGH GRADE ACID PHOSPHATE. Lewisburg Milling and Electric Co., Lewisburg. Guarantee-Phosphoric acid, soluble, 10 ; reverted, 4 ; insoluble, 1 ; total, 15 ; available, 14; phosphoric acid from mineral phosphates. Found: Phosphoric acid, soluble, 7.55 ; reverted, 8.10 ; insoluble, 0.67 ; total, 16.32 ; available, 15.65 .

\section{RASIN MONUMENTAL COMPANY.}

BALTimore, MD.

4395 RASIN'S ARUNDEL COMPLETE. B. T. Stone, Tunnelton. Guarantee-Phosphoric acid, soluble, 7 ; reverted, 
1 ; insoluble, 1.50 ; total, 9.50 ; available, 8 ; nitrogen, 1.64 ; potash, 2; phosphoric acid from Charleston, Florida and Tennessee rock, bone tankage, and fish; nitrogen from bone tankage and fish; potash from muriate and manure salts. Found: Phosphorie acid, soluble, 6.13; reverted, 3.58; insoluble, 1.09; total, 10.80; available, 11.71 ; nitrogen, 1.68 ; potash, 2.12 ; chlorine, 2.1 ; availability of nitrogen, 81 .

4441 SEAWALL SPECIAL. George T. Carskardon, Keyser. Guarantec-Phosphoric acid, soluble, 9; reverted, 1; insoluble, 1.50 ; total, 11.50; available, 10 ; phosphoric acid from Charleston, Florida and Temnessee roek. Found: Phosphorice aeid, soluble, 4.81; reverted, 9.74 ; insoluble, 1.25 ; total, 15.80 ; available, 14.55 .

4406 RASIN'S DISSOLVED BONE. C. W. Mayer, Som \& Company, Terra Alta. Guarantee-Phosphoric acid, soluble, 8 ; reverted, 2 ; insoluble, 1.50 ; total, 11.50 ; available, 10 ; nitrogen, 1.64; phosphoric acid from bone and bone tankage; nitrogen from bone. Found: Phosphoric acid, 6.08; reverted, 5.69; insoluble, 3.42 ; total, 15.19 ; available, 11.77 ; nitrogen, 1.64; availability of nitrogen, 82 .

4404 RASIN'S BONE AND POTASH FERTILIZER. C. W. Mayer, Sons' \& Company, Terra Alta. Guarantee-Phosphoric acid, soluble, 9 ; reverted, 1 ; insoluble, 1.50 ; tota 11.50 ; available, 10 ; potash, 2 ; phosphoric acid from Charleston, Florida and Tennessee roek; potash from muriate and manure salts. Found: Phosphoric acid, soluble, 7.66 ; reverted, 3.37; insoluble, 1.39; total, 12.42; available, 11.03; potash; 2.17 ; chlorine, 2.2 .

4442 RASIN'S BONE AND POTASH FERTILIZER. George T. Carskadon, Keyser. Guarantee-(As above). Found: Phosphoric acid, soluble, 6.93; reverted, 4.30; insoluble, 1.32; total, 12.55 ; available, 11.23 ; potash, 2.98 ; chlorine, 1.3.

4545 RASIN'S BONE AND POTASH FERTILIZER. 
C. W. Mayer, Son \& Co., Terra Alta. Guarantee-(As above). Found: Phosphoric acid, soluble, 3.44 ; reverted, 6.77 ; insoluble, 2.51 ; total, 12.72 ; a vailable, 10.21 ; potash, 1.81 ; chlorine, 2.3 .

4563 RASIN'S ACID PHOSPHATE. G. 'T. Hodges, Shepherdstown. Guarantee-Phosphoric acid, soluble, 12; reverted, 2; insoluble, 1; total, 15; available, 14; phosphoric acid from Charleston, Florida and Tennessee rock. Found: Phosphoric acid, soluble, 11.99 ; reverted, 4.38 ; insoluble, 0.49 ; total, 16.86 ; available, 16.37 .

4569 RASIN'S ACID PHOSPHATE. P. W. Atkinson, Berkeley Springs. Guarantee-(As above). Found:. Phosphoric acid, soluble, 12.46; reverted, 4.83 ; insoluble, 2.62 ; total, 19.91 ; available, 17.29.

4394 RASIN'S ACID PHOSPHATE. B. 'T. Stone, Tunnelton. Guarantec-(As above). Found: Phosphoric acid, soluble, 10.84 ; reverted, 4.03 ; insoluble, 2.46 ; total, 17.33 ; available, 14.87 .

4405 RASIN'S ACID PHOSPHATE. C. W. Mayer, Son \& Company, Terra Alta. Guarantee-(As above). Found: Phosphoric acid, soluble, 5.95; reverted, 9.18; insoluble, 1.69; total, 16.82 ; available, 15.13.

4440 RASIN'S ACID PHOSPHATE. George T. Carskadon, Keyser. Guarantee-(As above). Found: Phosphorie acid, soluble, 13.55 ; reverted, 2.60 ; insoluble, 1.09 ; total, 17.24; available, 16.15 .

4546 RASIN'S ACID PHOSPHATE. C. W. Mayer, Son \& Company, Terra Alta. Guarantee-(As above). Found: Phosphoric acid, soluble, 11.05; reverted, 4.61; insoluble, 3.93; total, 19.59 ; available, 15.66 .

4396 WILLIAM PENN CROP GROWER. B. T. Stone, Kingwood. Guarantee-Phosphoric acid, soluble, 7 ; reverted, 1 ; insoluble, 1 ; total, 9 ; available, 8 ; nitrogen, 0.82 ; potash, 1 ; 
phosphoric acid from Charleston, Florida and Tennessee roek and bone tankage; nitrogen from tankage and bone; potash from muriate and manure salts. Found: Phosphoric acid, soluble, 5.65 ; reverted, 3.57 ; insoluble, 0.68 ; total, 9.80 ; available, 9.12 ; nitrogen, 1.07 ; potash, 1.28 ; ehlorine, 1.9 ; availability of nitrogen, 73 .

4506 WILLIAM PENN CROP GROWER. J. M. Miller and Brother, Roneeverte. Guarantee-(As above). Found: Phosphoric aeid, soluble, 3.97; reverted, 5.14; insoluble, 1.27; total, 10.38; available, 9.11 ; nitrogen, 1.01 ; potash, 1.20 ; chlorine, 1.8 ; availability of nitrogen, 87.

\section{RICIIMOND GUANO COMPANY.}

Richmond, Virginia.

4507 HIGH GRADE ACID PHOSPIIATE. J. M. Miller and Brother, Roneeverte. Guarantee-Phosphoric aeid, soluble, 8 ; reverted, 6 ; insoluble, 1 ; total, 15 ; available, 14 ; plosphorı acid from mineral phosphate. Found: Phosphoric acid, soluble, 6.82; reverted, 8.97; insoluble, 0.75; total, 16.54; available, 15.79 .

\section{SCIENTIFIC FERTIIAZER COMPANY.}

\section{Pittsburg, Pennsyluania.}

4636 SCIENTIFIC CORN AND GRAIN. Walter Marshall, Wheeling. Guarantee-Phosphorie aeid, soluble, 4; reverted, 4 ; insoluble, 1 ; total, 9 ; available, 8 ; nitrogen, 1.50 ; potash, 2; phosphorie acid, one-third from tankage, two-thirds from mineral phosphate; nitrogen from tankage and blood; potash from sulphate of potash. Found: Phosphoric acid, soluble, 3.53; reverted, 3.14 ; insoluble, 1.75 ; total, 8.42 ; available, 6.67 ; nitrogen, 1.03 ; potash, 2.39 ; ehlorine, 2.3 ; availability of nitrogen, 83. Remarl-Source of potash not as guaranteed; is equivalent to kainit. 
4635 SCIENTIFIC GRAIN GROWER. Walter Marshall, Wheeling. Guarantee-Phosphoric acid, soluble, 4; reverted, 4 ; insoluble, 1 ; total, 9 ; available, 8 ; nitrogen, 0.82 ; potash, 1 ; phosphoric acid, one-fifth from tankage, four-fifths from mineral phosphates; nitrogen from tankage and blood; potash from sulphate of potash. Found: Phosphoric acid, soluble, 3.71 ; reverted, 2.63; insoluble, 1.09; total, 7.43 ; available, 6.34 ; nitrogen, 1.09 ; potash, 1.06 ; chlorine, 3.1 ; availability of nitrogen, 67. Remark-Source of potash not as guaranteed; is equivalent to kainit; availability of nitrogen low.

4638 PURE RAW BONE MEAL. Walter Marshall, Wheeling. Guarantee-Phosphoric acid, total, 22; nitrogen, 3.25; phosphoric acid from bone; nitrogen from bone. Found: Phosphoric acid, total, 24.84 ; nitrogen, 2.39 ; availability of nitrogen, 88.

\section{SWIFT \& COMPANY.}

Chicago, Ilis.

4456 SWIFT'S SUPER-PHOSPHATE. Sencindiver \& Stewart, Martinsburg. Guarantee-Phosphoric acid, insolub?e, 4 ; total, 12 ; available, 8 ; nitrogen, 1.64 ; potash, 2 ; phosphoric acid from bone and phosphate rock; nitrogen from blood and tankage; potash from muriate. Found: Phosphoric acid, soluble, 6.29 ; reverted, 6.76 ; insoluble, 2.02 ; total, 15.07 ; available, 13.05 ; nitrogen, 1.93 ; potash, 2.20 ; chlorine, 0.9 ; availability of nitrogen, 84 .

4466 SWIFT'S SUPER-PHOSPHATE. A. M. Carson Store Company, Ripley. Guarantee-(As above). Found: Phosphoric acid, soluble, 7.07 ; reverted, 3.32 ; insoluble, 2.17; total, 12.56 ; available, 10.39 ; nitrogen, 1.54 ; potash, 2.26 ; chlorine, 1.0 ; availability of nitrogen, 81 .

4540 SWIFT'S SUPER-PHOSPHATE, Washington \& Alexander, Charles Town. Guarantee-(As above). Found: 
Phosphorie acid, soluble, 2.65; reverted, 5.94; insoluble, 2.48; total, 11.07 ; available, 8.59 ; nitrogen, 1.65 ; potash, 2.04 ; chlorine, 1.0 ; availability of nitrogen, 92 .

4457 SWIFT'S COMPLETE FERTILIZER. Senei!diver \& Stewart, Martinsburg. Guarantce-Phosphoric acid, insoluble, 3 ; total, 11 ; available, 8 ; nitrogen, 1 ; potash, 1 ; phosphorie aeid from bone and phosphate roek; nitrogen from blood and tankage; potash from muriate. Found: Phosphoric acid, soluble, 6.37 ; reverted, 4.80 ; insoluble, 2.01 ; total, 13.18 ; available, 11.17 ; nitrogen, 1.33 ; potash, 1.15 ; chlorine, 1.0 ; availability of nitrogen, 86 .

4467 SWIFT'S COMPLETE FERTILIZER. A. M. Carson Store Company, Ripley. Guarantee-(As above). Found: Phosphorie acid, soluble, 5.42; reverted, 4.56; insoluble, 2.35; total, 12.33; available, 9.98 ; nitrogen, 1.00 ; potash, 1.68 ; chlo:ine, 1.2 ; availability of nitrogen, 85 .

4538 SWIFT'S COMPLETE FERTILIZER. Washington \& Alexander, Charles Town. Guarantee-(As above). Found: Phosphorie acid, soluble, 3.56; reverted, 3.87 ; insolible, 1.33 ; total, 8.76 ; available, 7.43 ; nitrogen, 1.01 ; potash, 1.01 ; chlorine, 1.4 ; availability of nitrogen, 86 .

4443 SWIFT'S BONE MEAL. George T. Carskadon, Keyser. Guarantee-Phosphoric aeid, total, 25; nitrogen, 2.50 ; phosphoric aeid from bone; nitrogen from bone. Found: Phosphoric aeid, total, 25.92; nitrogen, 2.50 ; availability of nitrogen, 87.

4455 SWIFT'S BON EMEAL. Sencindiver \& Stewart, Martinsburg. Guarantee-(As above). Found: Phosphorie acid, total, 26.19; nitrogen, 2.42; availability of nitrogen, 94 .

4468 STIFT'S BONE MEAL. A. M. Carson Store Company, Ripley. Guarantee-(As above). Found: Phosphoria acid, total, 26.07 ; nitrogen, 2.48 ; availability of nitrogen, 89. 
4539 SWIFT'S BONE MEAL. Washington \& Alexander, Charles Town. Guarantee-(As above). Found: Phosphoric acid, total, 26.23; nitrogen, 2.56; availability of nitrogen, 90.

\section{VIRGINIA-CAROLINA CHEMICAL COMPANY.}

\section{Richmond VIRGINIA.}

4511 ALLISON \& ADDISON STAR BRAND GUANO. J. M. Miller and Brother, Ronceverte. Guarantee-Phosphoric acid, soluble, 6 ; reverted, 2 ; insoluble, 1 ; total, 9 ; available, 8 ; nitrogen, 1.65; potash, 1; phosphoric acid from phosphate roci and animal bone; nitrogen from fish tankage, blood, nitrate of soda, sulphate of ammonia and cotton seed meal; potash froin muriate and sulphate. Found: Phosphoric acid, soluble, 4.71; reverted, 3.80 ; insoluble, 1.55 ; total, 10.06 ; available, 8.51 ; nitrogen, 1.92 ; potash, 1.26 ; chlorine, 1.6 ; availability of nitrogen, 93. Remark-Source of potash equivalent to muriate.

4601 ALLISON \& ADDISON STAR BRAND GUANO. E. W. McNeer, Lowell. Guarantee-(As above). Found: Phosphoric acid, soluble, 5.95 ; reverted, 3.73 ; insoluble, 1.73 ; totai, 11.41; available, 9.68 ; nitrogen, 1.65 ; potash, 1.30 ; chlorine, 1.); availability of nitrogen, 88. Remark-Source of potash equivalent to muriate.

4509 ALLISON \& ADDISON LITTLE GIANT GRALN AND GRASS GROWER. J. M. Miller \& Brother, Ronceverte. Guarantee-Phosphoric acid, soluble, 6; reverted, 2; insoluble, 1 ; total, 9 ; available, 8 ; nitrogen, 0.82 ; potash, 2 ; phosphoric acid from phosphate rock and animal bone; nitrogen from fish tankage and cotton seed meal; potash from muriate and sulphate of potash. Found: Phosphoric acid, soluble, 4.89; reverter, 3.72 ; insoluble, 1.04 ; total, 9.65 ; available, 8.61 ; nitrogen, 0.84 ; potash, 1.90 ; chlorine, 2.4 ; availability of nitrogen, 89 . Remark-Source of potash equivalent to kainit. 
4603 ALLISON \& ADDISON LITTLE GIANT GRAIN AND GRASS GROWER. E. W. MeNeer, Lowell. Guarantec(As above). Found: Phosphoric acid, soluble, 6.63; reverted, 2.96; insoluble, 1.73 ; total, 11.32 ; available, 9.59 ; nitrogen, 0.82 : potash, 1.84; chlorine, 2.00; availability of nitrogen, 82. Remark-Source of potash equivalent to low grade muriate.

4510 ALLISON \& ADDISON STANDARD ACID PIIOSPHATE. J. M. Miller \& Brother, Ronceverte. GuaranteePhosphoric acid, soluble, 9 ; reverted, 3 ; insoluble, 1.50 ; tota!, 13.50; available, 12; phosphoric acid from phosphate rock. Found: Plosphoric acid, soluble, 5.63; reverted, 7.26 ; insolutble, 2.00 ; total, 14.89 ; available, 12.89 .

4602 ALLISON \& ADDISON STANDARD ACID PIIOSPIIATE. E. W. MeNeer, Lowell. Guarantec-(As above). Found: Phosphoric acid, soluble, 6.84; reverted, 7.02; insoluble, 1.52; total, 15.38; available, 13.86 .

4600 J. C. TINSLEY \& COMPANY'S "STONE WALE" BRAND ACID PIIOSPHATE. E. W. MeNeer, Lowell. Guarantec-Phosphoric acid, soluble, 7; reverted, 3; insoluble, 1; total, 11; available, 10; phosphoric acid from phosphate rock. Found: Phosphoric aeid, soluble, 7.79; reverted, 4.83; insoluble, 1.34 ; total, 13.96 ; available, 12.62 .

4533 VIRGINIA-CAROLINA CHEMICAL COMPANY'S GUARANTEED 14 PER CENT ACID PIIOSPIIATE. Washington \& Alexander, Charles Town. Guarantee-Phosphoric acid, soluble, 12 ; reverted, 2 ; insoluble, 1 ; total, 15 ; availab!e, 14; phosphoric acid from Tennessee, Florida and Charleston roeks. Found: Phosphoric acid, soluble, 7.81; reverted, 10.65; insoluble, 0.55 ; total, 19.04 ; available, 18.49 .

4564 VIRGINIA-CAROLINA CIEIICAL COMPANY'S GUARANTEED 14 PER CENT ACID PIIOSPHATE. G. १. IIodges, Shepherdstown. Guarantee-(As above). Found: 
Phosphoric acid, soluble, 13.35; reverted, 3.22; insoluble, 1.55; total, 18.15 ; arailable, 16.60.

\section{TIRGINLA-CAROLINA CHEMICAL COMPANY S} STANDARD BONE AND POTASH. Washington \& Alexander. Charles Tomn. Guarantee-Phosphoric acid, soluble, 9; r.rerted, 1: insoluble, 1; total, 11: arailable, 10; potash, 2; phosphoric acid from Tennessee, Florida and Charleston rock; potash from muriate and manure salts. Found: Phosphoric acid, soluble, 4.05 ; reverted, 6.45 ; insoluble, 2.48 ; total, 13.01 ; available, 10.53; potash, 1.13; chlorine, 3.4. Remark-Source of potash equivalent to kainit.

\section{TRATERS THEAT ATD GRASS FERTILIZER.} L. P. Wills, Ansted. Guarantee-Phosphoric acid, soluble, 6; reverted, 2; insoluble, 2: total, 10 ; available, 8 ; nitrogen, 0.82 ; potash, 1; phophoric acid from phosphate rock and animal bons; nitrogen from fish, animal tankage and cotton seed meal; potash from muriate, sulphate and double manure salt. Found: Phosphoric acid, soluble, 4.59; reverted, 4.05; insoluble, 1.12; totai, 9.76; available, 8.6t; nitrogen, 1.03; potash, 1.04; chlorine, 1.6; availability of nitrogen, 80 . Remark-Source of potash equivalent to muriate.

4489 TRATERS BEEF, BLOOD AND BOYE FERTILIZER. L. P. Wills, Ansted. Guarantee-Phosphoric acid, soluble, 6 ; rererted, 2 ; insoluble, 2 ; total, 10 ; arailable, 8 ; nitrogen, 1.65 ; potash, 1: phosphoric acid from phosphate rock and animal bone: nitrogen from fish, animal tankage and cotton seed meal; potash from muriate, sulphate, double manure salt. Found: Phosphoric acid, soluble, 1.99; reverted, 3.79; insoluble, 1.07; total, 9.85 ; available, 8.78 ; nitrogen, 1.30 ; potash, 1.02 ; chlorine, 2.5 ; arailability of nitrogen, 80 . Remark-Source of potash equivalent to kiainit. 
IZER. E. W. MeNeer, Loweill. Guarantee-(As above). Found: Phosphoric acid, soluble, 6.52; reverted, 2.88; insoluble, 1.19; total, 10.59 ; available, 9.40 ; nitrogen, 1.86 ; potash, 2.07 ; chlorine, 2.3; availability of nitrogen, 85 . Remark-Source of potash cquivalent to low grade muriate.

4508 TRAVER'S CHAMPION CORN GROWER FERTILIZER. J. M. Miller \& Bro., Ronceverte. Guarantee-Phosphoric acid, soluble, 6 ; reverted, 2 ; insoluble, 2 ; total, 10 ; available, 8 ; nitrogen, 0.82 ; potash, 1 ; phosphoric acid from phosphate rock aud animal bone; nitrogen from fish, animal tankage, and cotton seed meal; potash from muriate, sulphate and double manure salt. Found: Phosphoric acid, soluble, 5.41; reverteü, 5.37 ; insoluble, 0.95 ; total, 11.73 ; available, 10.78 ; nitrogen, 1.00 , potash, 1.2.2; chlorine, 0.9 ; availability of nitrogen, 88 . Remark-Source of potash equiralent to high grade muriate.

$44 S 8$ TRATER'S CAPITOL BONE AND POTASII COMPOUND. L. P. Wills, Ansted. Guarantee-Phosphoric acid, soluble, 7 ; reverted 3 ; insoluble, 1 ; total, 11 ; available, 10 ; potash, 2; phosphoric acid from phosphate rock; potasl from muriate, sulphate and double manure salt. Found: Phosphoric acid, soluble, 3.72 ; reverted, 6.40 ; insoluble, 1.52 ; total, 11.64 ; available, 10.12; potash, 1.60 ; chlorine, 2.1. Remark-Source of potash equiralent to kainit. ate.

4487 TRAVER'S CAPITOL DISSOLVED S. C. BONE. L. P. Wills, Ansted. Guarantee-Phosphoric acid, soluble, 9; reverted, 3 ; insoluble, 1 ; total, 13 ; available, 12; phosphoric acid from phosphate rock. Found: Phosphoric acid, soluble, 6.04 ; reverted, 4.44 ; insoluble, 1.84 ; total, 12.32 ; available, 10.48.

4621 TRATER'S CAPITOL DISSOLVED S. C. BONE. E. W. MeNeer, Lowell. Guaranteed-(As above). Found: Phosphoric acid, soluble, 6.86; reverted, 5.93; insoluble, 1.37; total, 14.16; available, 12.79 . 


\title{
VIRGINIA STATE FERTILIZER COMPANY.
}

\author{
LyNChbURG, Virginia.
}

4522 VIRGINIA STATE HIGH GRADE GUANO. Payne Brothers, Seebert. Guarantee-Phosphoric acid, insoluble, 1; total, 9 ; available, 8 ; nitrogen, 2; potash, 2 ; phosphoric acid from Tennessee phosphate rock; nitrogen from tankage; potash from sylvinit. Found: Phosphoric acid, soluble, 6.37; reverted, 4.41; insoluble, 0.68 ; total, 11.46 ; available, 10.78; nitrogen, 1.43 ; potash, 1.74 ; chlorine, 2.7 ; availability of nitrogen, 92 .

4523 MOUNTAIN TOP BONE AND POTASH MIXTURE. Payne Brothers, Seebert. Guarantee-Phosphoric acid, insoluble, 1; total, 11; available, 10; potash, 5; phosphoric acil from Tennessee phosphate rock; potash from sylvinit. Found: Soluble phosphoric acid, 7.74; reverted, 4.70; insoluble, 0.51; total, 12.95; available, 12.44; potash, 5.27; chlorine, 1.5 . Remark-Source of potash equivalent to muriate.

4524 BLOOD AND BONE PHOSPHATE. Payne Brothers, Seebert. Guarantee--Phosphoric acid, insoluble 1; total, 10; available, 9 ; nitrogen, 1 ; potash, 1 ; phosphoric acid from Tellnessee phosphate rock; nitrogen from tankage; potash from sylvinit. Found: Phosphoric acid, soluble, 5.82; reverted, 4.84; insoluble, 1.10 ; total, 11.76 ; available, 10.66 ; nitrogen, 0.86 ; potash, 1.21; chlorine, 2.8 ; availability of nitrogen, 90 .

4525 "GILT EDGE" BRAND ACID PHOSPHATW. Payne Brothers, Seebert. Guarantee-Phosphoric acid, insoinble, 1; total, 15; available, 14; phosphoric acid from Tennessere phosphate rock. Found: Phosphoric acid, soluble, 9.20; reverted, 5.72; insoluble, 1.15; total, 16.07; available, 14.92. 


\section{WALKER STRATIIAN \& COMPANY.}

Pittsburg, Pennsyluania.

4626 HELP MATE. Cox Brothers, West Union. Guarantce-Phosphoric acid, soluble, 7; reverted, 5; insoluble, 1; total, 13 ; available, 12 ; phosphorie acid from mineral phosphate. Found: Phosphorie acid, soluble, 4.68; reverted, 5.79; insoluble, 2.48 ; total, 12.95 ; available, 10.47 .

4637 HELP MATE. Pullman Hardware Company, Pullman. Guarantee-(As above). Found: Phosphoric aeid, soluble, 4.22 ; reverted, 6.72 ; insoluble, 2.15 ; total, 13.09 ; available, 10.94 .

4627 BONE AND MEAT. Cox Brothers, West Union. Guarantee-Phosphorie acid, total, 16; nitrogen, 3.25; phosphoric acid from bone and tankage; nitrogen rrom bone and tankage. Found: Phosphorie acid, total, 16.14; nitrogen, 3.51; availability of nitrogen, 93 .

4644 BONE AND MEAT. Lazear Brothers, Sistersvillr. Guarantee-(As above). Found: Phosphorie acid, total, 18.54; nitrogen, 3.01; availability of nitrogen, 93 .

4625 FOUR FOLD. Cox Brothers, West Union. Guarantee-Phosphoric acid, soluble, 4; reverted, 4; insoluble, 1; total, 9 ; available, 8 ; nitrogen, 1.50 ; potash, 2 ; phosphoric acid, one-third from tankage, two-thirds from mineral phosphate; nitrogen from blood and tankage; potash from sulphate of potash. Found: Phosphorie aeid, soluble, 4.08; reverted, 3.70; insoluble, 0.64 ; total, 8.42 ; available, 7.78 ; nitrogen, 0.97 ; potash, 2.20 ; ehlorine, 2.4; availability of nitrogen, 79. Remark-Source of potash equivalent to kainit; sulphate was guarantecd.

4639 FOUR FOLD. Lazear Brothers, Sistersville. Guarantee-(As above). Found: Phosphorie acid, soluble, 3.65; reverted, 3.41 ; insoluble, 2.02 ; total, 9.08 ; available, 7.06 ; nitrogen, 
0.97 ; potash, 2.28 ; chlorine, 2.5 ; availability of nitrogen, $87 . R e_{-}$ mark-Source of potash equivalent to kainit.

4639 FOUR FOLD. Lazear Brothers, Sistersville. Guarantee-(As above). Found: Phosphoric acid, soluble, 3.65; reverted, 3.41 ; insoluble, 2.02 ; total, 9.08 ; available, 7.06 ; nitrogen, 0.97 ; potash, 2.28 ; chlorine, 2.5 ; availability of nitrogen; 87. Remark-Source of potash equivalent to kainit.

\section{ROBER'T A. WOOLDRIDGE COMPANY.}

Baitimore, Md.

4609 FLORIDA ACID PHOSPHATE. J. H. Philipps, Berkeley Springs. Guarantee-Available phosphoric acid, 14, from dissolved phosphate rock. Found: Phosphoric acid, soluble, 11.58; reverted, 4.55; insoluble, 1.27 ; total, 17.40 ; available, 16.13 .

4449 GERMAN POTASH MIXTURE. J. W. Loughery, Rowlesburg. Guarantee-Available phosphoric acid, 10, froil dissolved phosphate rock; potash, 2, from German kainit.Found: Phosphoric acid, soluble, 1.29; reverted, 8.31 ; insoluble, 1.85; total, 11.45 ; available, 9.60 ; potash, 2.02 ; chlorine, 3.4 .

4370 LIBERTY BELL POTASH MITTURE. E. F. Wadsworth, Ashley. Guarantee-Available phosphoric acid, 12, from dissolved phosphate rock; potash, 3 , from kainit and manure salts. Found: Phosphoric acid, soluble, 10.06; reverted, 2.39; insoluble, 0.26 ; total, 12.61; available, 12.35; potash, 3.01 ; chlorine, 1.5 .

4463 LIBERTY BELL POTASII MIXTURE. J. W. Loughery, Rowlesburg. Guarantee-(As above). Found: Phosphoric acid, soluble, 10.09; reverted, 2.78 ; insoluble, 0.13; totai, 13.00 ; available, 12.87 ; potash, 3.15 ; chlorine, 2.3.

4589 LIBERTY BELL POTASH MIXTURE. F.T. Fesler, Philippi. Guarantee-(As above). Found: Phosphoric 
acid, soluble, 8.06 ; reverted, 3.59 ; insoluble, 0.49 ; total, 12.14; available, 11.65 ; potash, 2.58 ; chlorine, 2.7 . Remark-Source of potash equivalent to kainit.

4416 CHAMPION GIANT PHOSPHATE. C. B. Borgman, Howsville. Guarantee-Phosphoric acid, available, 9; from dissolved phosphate rock and dissolved animal bone; nitrogen, 1; from high grade tankage and fish; potash, 2; from manure salts and kainit. Found: Phosphoric acid, soluble, 6.83; reverted, 4.57; insoluble, 0.73 ; total, 12.13; available, 11.40; nitrogen, 1.07 ; potash, 2.36 ; chlorine, 4.1 ; availability of nitrogen, 79. Remark-Source of potash equivalent to kainit.

4458 CHAMPION GIANT PHOSPHATE. J. W. Loughery, Rowlesburg. Guarantee-(As above). Found: Phosphoric acid, soluble, 7.10 ; reverted, 1.96 ; insoluble, 0.50 ; total, 9.56 ; available, 9.06 ; nitrogen, 1.09 ; potash, 2.59 ; chlorine, 4.00 ; availability of nitrogen, 74. Remark-Source of potash equivalent to kainit.

4616 CHAMPION GIANT PHOSPHATE. J. H. Philipps and Sons, Berkeley Springs. Guarantee-(As above). Found: Phosphoric acid, soluble, 5.19; reverted, 5.89; insoluble, 1.25; total, 12.33; available, 11.08; nitrogen, 1.01 ; potash, 2.07 ; chlorine, 3.8 ; availability of nitrogen, 63 . RemarkSource of potash equivalent to kainit; availability of nitrogen low.

4588 CHIEFTAIN BONE AND STOCK PHOSPHATE. F. J. Fesler, Philippi. Guarantee-Phosphoric acid, available, 8, from dissolved phosphate rock and dissolved animal bone; nitrogen, 2 ; from high grade tankage, blood and fish; potash, 2, from manure salts and kainit. Found: Phosphoric acid, soluble, 4.31; reverted, 4.21; insoluble, 1.41 ; total, 9.93 ; available, 8.52 ; nitrogen, 2.18 ; potash, 2.13 ; chlorine, 3.3 ; availability of nitrogen, 87. Remark-Source of potash equivalent to kainit. 
4371 TRIUMPH BONE STOCK PHOSPHATE. E. F. Wadsworth, Ashley. Guarantee-Phosphoric acid, arailable, 8, from dissolved phosphate rock and dissolved animal bone; nitrogen, 1.50, from high grade tankage, blood and fish; potash, 4, from manure salts and muriate. Found: Phosphoric acid, soluble, 6.90 ; reverted, 2.05 ; insoluble, 0.79 ; tota, 9.74 ; available, 8.95 ; nitrogen, 1.30 ; potash, 3.94 ; chlorine, 2.3 ; availability of nitrogen, 83. Remark-Source of potash equiralent to low grade muriate.

4451 DOUBLE QUICK BONE PHOSPHATE. J. W. Loughery, Rowlesburg. Guarantee-Phosphoric acid, available, 9, from dissolved phosphate rock and dissolved animal bone; nitrogen, 2,75, from high grade tankage, blood and sulphate of ammonia; potash, 3, from ligh grade muriate and manure salts. Found: Phosphoric acid, soluble, 6.32 ; reverted, 2.36 ; insoluble, 0.95 ; total, 9.71 ; available, 8.76 ; nitrogen, 2.46 ; potash, 3.15; chlorine, 2.5 ; availability of nitrogen, 88 . Remark-Source of potash not as guaranteed; is equivalent to kainit.

4372 SPECIAL POTATO FERTILIZER. E. F. Wadsworth, Ashley. Guarantee-Phosphoric acid, available, 9, from dissolved phosphate rock and dissolved animal bone; nitrogen, 2, from tankage, blood and fish; potash, 5, from high gracie muriate and manure salt. Found: Phosphoric acid, soluble, 8.57; reverted, 1.17 ; insoluble, 0.84 ; total, 10.58 ; available, 9.74 ; nitrogen, 1.87 ; potash, 5.91 ; chlorine, 1.8 ; availability of nitrogen, 90 . 


\section{Registered Brands.}

The following is a list of the brands which have been registered, as required by law, for the year ending Deeember 31, 1902 :

\section{AMERICAN AGRICULTURAL CHEMICAL DEPARTMENT}

\section{Baltumore Sales Department.}

Grain and Grass Grower.

Super-phosphate.

Gem Alkaline Bone.

Regular Corn Fertilizer.

Dissolved Animal Bone.

Bone Meal.

Fine Ground Bone.

Pure Ground Bone.

W. \& A. Special Fall Mixture.

Kainit.

Langdon Mixture.

Bradley's Dissolved Bone with Potash.

Bradley's Bean and Potato Potash.

Bradley's Niagara Phosphate.

Bradley's Alkaline Bone.

Canton Chemieal Eagle Phosphate.

Canton Chemical Potato Manure.

Canton Chemical Resurgam Guano.

Canton Chemical Game Guano.

Canton Chemical C. C. C. Special Compound. 
Canton Chemical Special Wheat, Corn and Grass Fertilizer. Canton Chemical "Harrow" Brand Crop Grower.

Canton Chemical Soluble Bone and Potash.

Canton Chemical Dissolved S. C. Bone.

Canton Chemical Soluble Alkaline Bone.

Canton Chemical Patrons Bone Mixture.

Cleveland Dryer Forest City Buckeye.

Cleveland Dryer Phospho Bone.

Cleveland Dryer Horse Head Phosphate.

Cleveland Dryer Horse Head Phosphate with Potash.

Cleveland Dryer XXX Phosphate.

Detrick Quick Step Bone Phosphate for Potatoes and Tobacco.

Detrick Soluble Bone Phosphate and Potash.

Detrick Kangaroo Komplete Kompound.

Detrick Dissolved S. C. Bone.

Detrick Standard Potash Fertilizer.

Detrick Corn and Oats Fertilizer.

Detrick Imperial Compound.

Detrick Paragon Ammoniated Dissolved Bone Phosphate and Potash.

Great Eastern Unammoniated Wheat Special.

Great Eastern Corn Fertilizer.

Great Eastern Vegetable, Vine and Tobacco.

Great Eastern English Wheat Grower.

Great Eastern Soluble Bone and Potash.

Great Eastern Dissolved Bone.

Lazaretto Bone Compound.

Lazaretto Special Potato Fertilizer.

Lazaretto Ammoniated Bone Phosphate.

Lazaretto Excelsior A. A. A.

Lazaretto Ammoniated Bone Phosphate.

Lazaretto Dissolved Bone Phosphate and Potash.

Lazaretto High Grade Dissolved Bone and Potash.

Maryland Ammoniated Bone. 
Maryland O. K. Ammoniated Fertilizer.

Maryland Tornado Fertilizer.

Maryland Bone Super-phosphate.

Maryland Dissolved S. C. Bone.

Pacific Nobsque Guano.

Pacific A. No. 1 Phosphate.

Pacific Potato Phosphate.

Pacific Dissolved Bone and Potash.

Pacific Dissolved Bone and Phosphate.

Reese's Half and Half.

Reese's Elm Phosphate.

Reese's High Grade Potash Mixture.

Susquehannah Alkaline Bone Phosphate.

Susquehannah Potato Phosphate.

Susquehannah XXV Phosphate.

Susquehannah Superior Rock Phosphate.

Tygert Allen Star Dissolved S. C. Rock.

Tygert Allen Corn and Oats Phosphate.

Williams \& Clark's Royal Bone Phosphate.

Williams \& Clark's Prolifie Crop Producer.

Williams \& Clark's Good Grower Potato Phosphate.

Williams \& Clark's Dissolved Bone and Potash.

Williams \& Clark's Acorn Acid Phosphate.

Zell's Special Compound for Potatoes and Vegetables.

Zell's Ammoniated Bone Super-phosphate.

Zell's Economizer Phosphate.

Zell's Little Giant.

Zell's Electric Phosphate.

Zell's Dissolved Bone Phosphate.

Zell's Dissolved S. C. Phosphate.

THE ABBOTT \& MARTIN RENDERING COMPANY.

Columbus, Онio.

Ideal Grain Grower. 


\section{ARMIOUR FERTILIZER WORKS.}

Baltimore, Maryland.

Star Phosphate.

Phosphate and Potash No. 1.

Ammoniated Bone with Potash.

High Grade Potao.

Grain Grower.

Wheat, Corn and Oats Special.

Cereal Phosphate.

Bone Meal.

THE BALTIMORE PULVERIZING COMPANY.

Baltimore, Maryland.

Special Fall Mixture.

\section{BAUGH \& SONS COMPANY.}

Baltimore, Maryland.

Baugh's Corn Fertilizer.

Baugh's Potato Fertilizer.

Baugh's Fish Mixture.

Baugh's Special Potato Manure.

Baugh's Raw Bone Super-phosphate.

Baugh's Peninsula Grain Produeer.

Baugh's Export Bone with Potash.

Baugh's Warranted Pure Bone Meal.

Baugh's Dissolved Animal Bones.

Baugh's Double Eagle Phosphate.

Baugh's General Crop Grower.

Baugh's Animal Bone and Potash Compound.

Baugh's Wheat Fertilizer.

Baugh's High Grade Acid Phosphate or Dissolved S. C. Roek.

Baugh's Soluble Alkaline Super-phosphate. 
Baugh's Exeelsior Super-phosphate.

Baugh's Ammoniated Soluble Alkaline.

BOWKER FERTILIZER COMPANY.

Boston, Mass.

Bowker's Ilarvest Bone.

Bowker's Dissolved Bone.

Bowker's Dissolved Bone with Potash.

Bowker's Soluble Bone.

Bowker's Bone Meal.

CHICAGO FERTIIIZER COMPANY.

Chic.igo, Ill.

Bone, Blood and Potash.

Wheat and Corn Special.

CINCINNATI PHOSPHATE COMPANY.

Cincinatati, Ohio.

Capitol Wheat Grower.

Capitol Grain and Grass Grower.

Capitol Dissolved Bone and Potash.

Capitol Super-phosphate.

Capitol Ground Bone.

Capitol Tobaceo Food.

L. FRANK \& SONS.

Zinesville, Ohio.

Enterprise.

Electric.

Antitrust.

S. II. IIESS \& BROTHER.

Philadelphi, Pa.

Wheat and Grass Manure. 
Soluble Bone and Potash.

Soluble Bone.

Emperor Phosphate.

Keystone Bone Phosphate.

\section{JARECHI CHEMICAL COMPANY.}

Sandusky, OHio.

No. 1 Fish Guano.

C. O. D. Phosphate.

Ground Bone.

Dissolved Bone with Potash.

Fish and Potash, Potato and Tobacco Food.

St. Bernard Phosphate.

Phosphate and Potash.

\section{LAZARETTO GUANO WORKS.}

Baltimore, Maryland.

Ruth's Dissolved Bone Phosphate.

Reliable.

Brodbeck's Alkaline Phosphate.

Nitrate of Soda.

MARIETTA BONE AND PHOSPHATE COMPANY.

Marietta, Ohio.

"Horse" Brand Pure Raw Bone.

"Horse" Brand Potato and Truck Special.

"Horse" Brand Corn, Oats and Wheat Grower.

"Horse" Brand Acid Phosphate.

NORTHWESTERN FERTILIZER COMPANY.

Chicago, Ill.

"Horse Shoe" Brand Garden City Super-phosphate. 


\section{G. OBER \& SONS' COMPANY.}

Baltimore, Maryland.

Ober's Dissolved Animal Bone.

Ober's Farmers Standard Ammoniated Phosphate. Ober's Farmers Mixture.

Ober's Independent Ammoniated Super-phosphate. Ober's Dissolved Bone Phosphate.

Ober's Dissolved Bone Phosphate and Potash.

Ober's High Grade Acid Phosphate.

Ober's Pure Raw Bone Meal.

Ober's Pure Bone Meal.

Ober's Special Mixture for Wheat.

Ober's S. \& S. Special Wheat Compound.

Ober's Shenandoah Bone Phosphate.

OHIO FARMERS' FERTILIZER COMPANY.

Columbus, Онiо.

Raw Bone Meal.

Corn, Oats and Wheat Fish Guano.

General Crop Fish Guano.

Wheat Maker and Seeding Down.

Pota and Tobaceo Special.

Acid Phosphate.

Superior Phosphate.

Soluble Bone and Potash.

PIEDMONT MT. AIRY GUANO COMPANY.

Baltimore, Miaryland.

Piedmont Pure Raw Bone Mixture.

Piedmont Royal Ammoniated Bone and Potash.

Piedmont Dissolved Bone Phosphate, Potash Goods.

Piedmont High Grade S. C. Bone.

Piedmont Potato Producer.

Piedmont Farmer's High Grade Bone and Potash. 
Piedmont "Plow" Brand.

Piedmont Special Potash Mixture.

Piedmont Soluble Bone and Potaosh.

Piedmont Harvest Queen.

Piedmont Farmers Favorite.

Isevering's Excelsior.

\section{R. H. POLLOCK.}

Baltimore, MD.

Poliock's Dissolved S. C. Bone.

Pollock's Victor Bone Phosphate.

Pollock's Special Wheat Grower.

Pollock's Ammoniated Bone Phosphate.

W. S. POWELL \& COMPANY.

Baltimore, MD.

Puwell's Dissolved S. C. Bone.

Powell's Bone and Potash.

Powell's Red Tag Fertilizer.

\section{POWHATAN CHEMICAL COMIPANY. Richmond, VA.}

Nagic Wheat Grower.

Magic Special Fertilizer.

Magic Ammoniated Phosphate.

Magic Bone and Potash Mixture.

Bone and Potash Nixture.

Dissolved S. C. Phosphate.

Virginia Dissolved Bone.

RASIN MONUMENTAL COMPANY.

Baltimore, Md.

Rasin's XXX Fertilizer.

Rasin's IXL Fertilizer. 
Rasin's Empire Guano.

Rasin's Bone and Potash Fertilizer.

Rasin's Acid Phosphate.

Rasin's Ammoniated Super-phosphate.

Rasin's Dissolved Bone.

William Penn Crop Grower.

A rundel Complete.

Speeial Formula Corn and Buekwheat.

Seawell Speeial.

Ionumental Potato Manure.

Monumental Acid Phosphate.

S. \& S. Special Wheat Compound.

RICHMOND GUANO COMPANY.

Richmond, VA.

"Premium" Brand Fertilizer.

"Premium" Brand Wheat Grower.

Bone Mixture.

Bone and Potash Mixture.

High Grade Acid Phosphate.

\section{SCIENTIFIC FERTILIZER COIIPANY.}

Pittsburg, Pi.

Scientifis Phosphate and Potash.

Seientific Dissolved Bone.

Seientifie Wheat and Clover.

Seientific Bone, Meat and Potash.

Seientific Bone and Potash.

Scientific Economy.

Scientific Potato.

Seientific Corn and Grain.

Scientific Grain Grower.

Bone and Meat.

Pure Raw Bone Meal.

High Grade Acid Phosphate. 


\section{SWIFT \& COMPANY.}

\section{Chicago, Ill.}

Swift's Super-phosphate.

Swift's Complete Fertilizer.

Swift's Bone and Potash.

Swift's Bone Meal.

Swift's Pure Raw Bone Meal.

Swift's Champion Wheat Grower.

Swift's Ammoniated Bone.

Swift's Virginia Tobacco Grower.

Swift's Champion Corn Grower.

Swift's Ammoniated Bone and Potash.

Swift's Vegetable Grower.

Swift's Potato and Tobacco Grower.

\section{P. THONIAS \& COMPANY.}

$$
\text { Philadeldita, Pa. }
$$

S. C. Phosphate.

Alkaline Bone.

\section{VIRGINIA-CAROLINA CHEMICAL COMPANY.}

$$
\text { Richmond, VA. }
$$

Allison \& Addison Star Brand Guano.

Allison \& Addison Little Giant Grain and Grass Grower.

Allison \& Addison Standard Acid Phosphate.

Allison \& Addison B. P. Potash Mixture.

J. G. Tinsley's Stone Wall Guano.

J. G. Tinsley's Wheat and Grass Grower.

J. G. Tinsley's Powhatan Phosphate.

J. G. Tinsley's Stone Wall Acid Phosphate.

J. G. Tinsley's Bone and Potash Mixture.

S. W. 'Travers' Wheat and Grass Fertilizer.

S. W. Travers' Beef, Blood and Bone Fertilizer.

S. W. Travers' Champion Corn Grower Fertilizer. 
S. W. Travers' Capitol Bone-Potash Compound.

S. W. Travers' Capitol Dissolved S. C. Bone.

S. W. Travers' Dissolved Bone Phosphate.

Standard Bone and Potash.

Guaranteed-14 per cent Acid Phosphate.

THE VIRGINIA STATE FERTILIZER COMPANY.

$$
\text { LYNCHBURG, VA. }
$$

Virginia State High Grade Guano.

Blood and Bone Phosphate.

Mountain Top Bone and Potash Mixture.

"Gilt Edge" Dissolved Bone and Potash.

"Gilt Edge" Acid Phosphate.

Lurich Acid Phosphate.

Bull Run Acid Phosphate.

WALKER, STRATMAN \& COMPANY.

Pittsburg, Pa.

Phosphoric Aeid and Potash.

Help Mate.

Pure Raw Bone.

Bone and Meat.

Grain King.

Acid Phosphate.

Meat, Blood and Bone with Potash.

Potash and Bone Phosphate.

Big Bonanza.

Potato Special.

Four Fold.

Grain Manure.

ROBERT A. WOOLDRIDGE COMPANY.

Baltimore, MD.

Florida Acid Phosphate. 
German Potash Mixture.

Liberty Bell Potash Mixture.

Old Sledge Phosphate.

Champion Giant Phosphate.

Chieftain Bone Stock Phosphate.

Triumph Bone Stock Phosphate.

Buffalo Bone Stock Phosphate.

Double Quick Bone Stock Phosphate.

Special Potato Fertilizer.

Sweepstakes "Sureshot" Truck Phosphate.

Golden Crown Truck Phosphate.

Pure Raw Bone. 


\title{
Unregistered Brands Found on Sale During 1902.
}

\section{BAUGH \& SONS' COMPANY.}

\author{
Baltimore, Md.
}

Baugh's Gennine German Kainit.

JARECHI CHEMICAL COMPANY.

SANDUSKY, O.

"Square" Brand Phosphate and Potash.

RAMSBERG FERTILIZER COMPANY.

Frederick, Md.

Ramsberg Dissolved Bone Super-phosphate.

Ramsberg Excelsior Plant Food.

\section{RASIN MONUMENTAL COMPANY.}

Baltimore, Md.

Rasin's Ground Bone.

VIRGINIA-CAROLINA CHEMICAL COMPANY.

RichMond, VA.

Ground Bone Meal.

Special Compound for Wheat. 


\section{List of Agents Whose Stock Was Sampled During 1902.}

Armstrong, Chrislip \& Company...............Buckhannon Allender Brothers......................... Toll Gate P. W. Atkinson ...................... Berkeley Springs C. H. Becker.......................... Wheeling

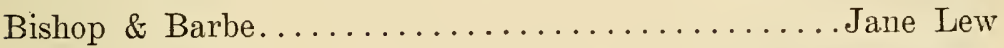
C. B. Borgman........................... Howsville Bush \& Sleeth........................... Toll Gate

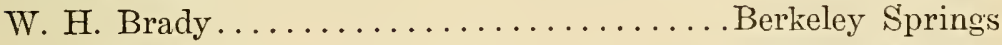
H. C. Bare Hardware Company.................Alderson

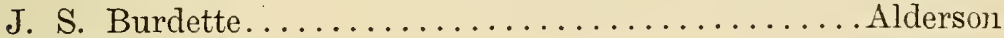
George Brinkman .........................Grafton

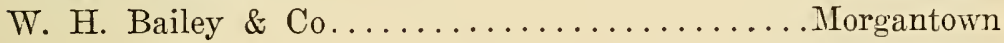
O. R. Carmen......................... Wellsburg W. L. Cole ............................ Clarksbur:s O. P .Cox \& Son........................... Toll Gate George T. Carskadon......................... Keyse: A. MI. Carson's Store Company...................... Ripley Cast \& Holden............................ Clarksburg J. J. Chisler............................ Fairmont

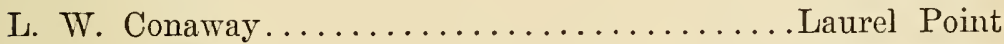
A. G. Chrislip .......................... Philippr Cox Brothers......................... West Union

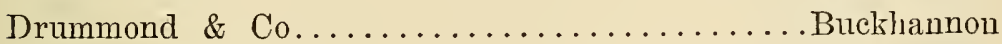

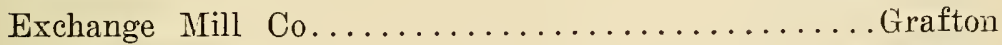

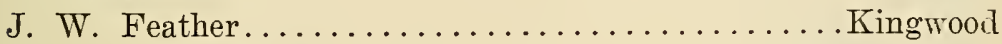
R. P. Floyd \& Son......................... Mannington

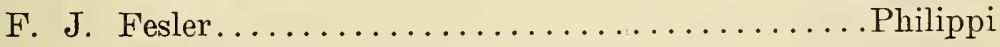

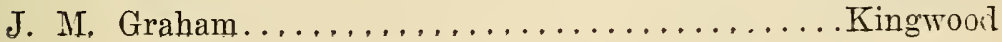


G. T. Hodges . Shepherdstown

G. W. Harvey Tunnelton

Henshaw \& Licklider....................... . . . . . . James Hawker .Mannington

J. I. Hall. . Fairmout

J. W. Hedrick. Alderson

J. M. Hagerty. Farmingtun H. J. Heck. Barrickville - - - Herring Kingwoo:l

R. Hunter Berkeley Springs

A. E. Huddleston White Sulphur Harry Johnson .Clarksburg Johnson \& Gwinn. Alderson R. A. Johnson. Parkersburg R. T. Lowndes. Clarksburg

J. W. Loughery Rowlesburg

Lewisburg Milling \& Electric Co. Lewisburg L. P. Licklider. Martinsbur's W. N. Lemon . Shepherdstown Lake \& MIcCarty. Jane Lew Lazear Brothers. Sistersville Mason \& Watson. . Kingwood C. W. Mayer, Son \& Co Terra Alta McKown \& Busey. Martinsburg J. W. and Jeff Miller Spencer

J. II. McIntosh \& Son. Ravenswood

J. M. Niller \& Bro Ronceverte

J. H. Miller \& Son. ...................... Martinsburg Mossman Brothers....................Huntington E. W. IIcNeer. Lowel! Talter Marshall Wheeling Offutt \& Kakin. Terra Alta Payne Brothers Seebert

C. Phillips Belington J. H. Phillips' Sons. Berkeley Springs 
Pullman Hardware Company................Pullman

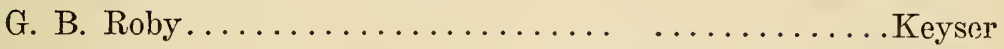
A. P. Russell \& Co....................... Buckhannon

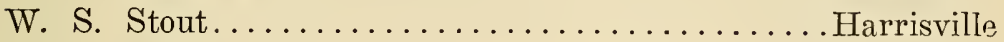

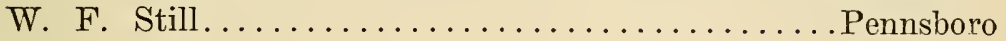

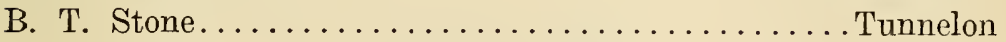

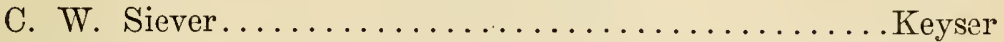

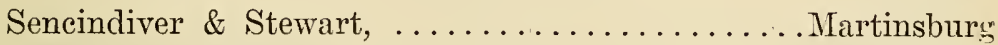
Shanklin Brothers ..................................

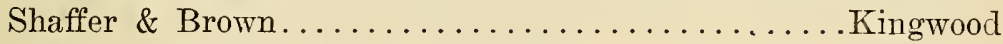
Spencer Milling Company................. Spencer S. J. Tailor............................ Toll Gate

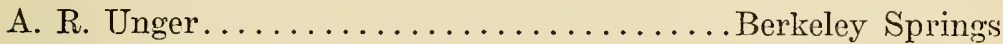

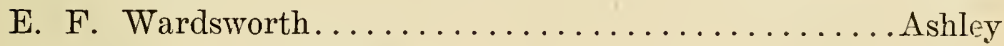

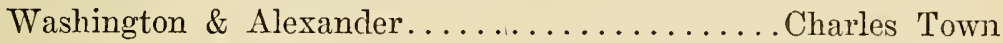
J. L. Woodyard. ...................... Pruntytown

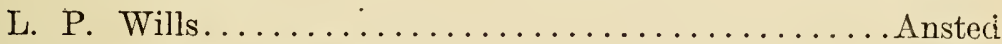

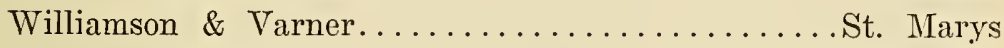
W. B. Wright. .......................... Law for 


\section{AN ACT}

\section{Concerning Commercial Fertilizers, State of West \\ Virginia.}

AN ACT concering commereial fertilizers, and repealing chapter seventy-two of the Acts of the Legislature of West Virginia, of eighteen hundred and ninety-one.

[Passed February 2d, 1901.]

Be it enacted by the Legislature of West Virginia:

1. Every person who shall sell, offer or expose for sale, or have in his possession with intent to sell in this State, any commercial fertilizer or manure, shall affix conspicuonsly to every package thereof a plainly printed statement, clearly and truly certifying the number of net pounds of fertilizer in a package, the name, brand or trade-mark under which the fertilizer is solrl, the name and address of the manufacturer, the place of manufacture, and stating the pereentage of nitrogen or its equivalent in ammonia; of potash, soluble in distilled water; and of phosphoric acid in available form, soluble in distilled water, reverted, as well as the total phosphoric acid, and the materials from which said constituents are derived. In the case of those fertiiizers which eonsist of other cheaper materials, said labels shall give a correct general statement of the composition and ingreilients of the elements relied upon, contained in the fertilizer which it accompanies.

2. Before any commereial fertilizer is sold, offered or ex- 
posed for sale in this State, the manufacturer, importer or party who causes it to be sold, exposed or ofiered for sale, shall file with the Director of the West Virginia Agricultural Experiment Station, under oath, the statement required to be affixed under section one of this act.

Provided, That when the manufacturer of any brand uf fertilizer or manure shall file said sworn statement no agent or dealer shall be required to file such statement. The making of any affidavit required by this chapter falsely shall be perjury.

3. The manufacturer, importer, agent or seller of any brand of commercial fertilizer or material used for manurial purposes, shall pay for each brand at the time he files a sworn statement required by section two of this act a registration fee of one dollar per annum.

4. The registration fee required to be paid by section three of this act, shall be paid to the treasurer of the West Virginia Universit yfor the use of the Agricultural Experiment Station, and the party making such payment shall take from the said treasurer triphicate receipts therefor, one of which he shall retain, and the others shall be deposited, one with the Director of the Agricultural Experiment Station, and the other with the secretary of the Board of Regents, and by thein filed and preserved in their respective offices.

5. Immediately after the filing of the receipts aforesaid, with the Director of the Agricultural Experiment Station, saju Director shall issue a certificate to the party making such payment, stating the amount of fees paid, and the name, brand or trade-mar kunder which the fertilizer is sold, the name and address of the manufacturer or importer, the place of manufacture, and that the applicant for said certificate is authorized to sell said fertiizer within the State of West Virginia for the period of one year from the first dayof January to the thirtyfirst day of December, inclusive. Said certificate may be issued at any time for and during the current year, and may be issued 
during the month of December for the year commeneing on the first day of January thereafter.

6. It shall be the duty of the Director of the West Virginia Agricultural Experiment Station to print or cause to be printer a label or tag setting forth the sworn statement required in section two of this act. The Director shall furnish such labels or tags in quantities in one hundred or multiples thereof, to any persun eomplying with the requirements of this act, and desiring to sell, offer or expose for sale any commereial fertilizer in this State, and shall receive pay therefor at the rate of forty cents for such number of labels or tags as may be required to be affixer to one ton of fertilizer, and shall without delay, pay the same to th etreasurer of the West Virginia University, for use of the Agrieultaral Experiment Station, and take duplicate recepits therefor, ne of which he shall retain, and the other he shall deliver to the secretary of the Board of Regents, who shall file and meserve the same in his office.

7. The Boure? of Regents of the West Virginia University shall expend the noney received under the provision of this act in meeting the legitimate expenses of the Station in making analyses of fertilizers, in experimental tests of same, and in such other experimenta! work and purehases as shall inure to the henefit of the farmers of this State, and shall include in their annual report a statiment of the receipts and disbursements thereof.

8. It shall he the duty of the Director of the said Experiment Station, in person or by deputy, to take samples for analysis from anv int or packages of any fertilizer or manure which may be in the possession of any dealer in the State, and he is hereby authorized to preseribe and enforee such rules and regulations as he may deem necessary to earry fully into effect the true intent and meaning of this act; and any agriculturist, purchaser of any fertilizer or manure in this State may take a sample of the same under the rules and regulations of the Director of the said Experiment Station and forward the same to him an- 
alysis, and if the Director has reason to believe that the manufacture of, or dealer in, such fertilizer or manure has made any false or fraudulent representations in regard to said fertilizer or manure, he shall canse the said sample to be analyzed free of charge, and certify the same to the person forwarding the sample. And it shall be the duty of every agent or dealer in fertilizers or manures, within the meaning of this act, in this State, when ordering consignments thereof, to promptly notify the Director of the said Experiment Station of the amount ordered, and the place and approximate time of delivery of said fertilizers and manures.

9. Said Director shall also publish by bulletin, the brand, name and location of the manufacturer and chemical analysis of every fertilizer or manure analyzed or caused to be analyzed by him. Said last publication to be made, if practicable, before the time at which said fertilizer is to be applied to the soil.

10. Any manufacturer or vendor of any fertilizer or manure who shall sell or offer or expose for sale any fertilizer or manure without having previously complied with the provisions of this act as hereinbefore set forth, shall be deemed guilty of a misdemeanor, and upon conviction thereof shall be fined not less than fifty nor more than fire hundred dollars.

11. Any company, firm or corporation who shall wilfully remove from or deface or change any label, or tag, or brand affixed to any package of fertilizer under the provisions of this act before such fertilizer has been used for manurial purposes, or who shall sell such fertilizer without such label or tag being affixed thereto at the time of the sale, shall be deemed guilty of a misdemeanor, and upon conviction thereof, shall be fined not less than ten nor more than fifty dollars for each offense.

12. Any company, firm or person who shall remove from or cause to be removed from any package of commercial fertilize: or manure any statement, label or tag affixed thereto under the provisions of this act, and affix or cause the same to be affixer to any other package of commercial fertilizer or manure, shatl 
be deemed guilty of a misdemeanor, and upon conviction thereuf shall be fined not less than ten nor more than fifty dollars f.r. each offense.

13. Any company, firm or person violating any of the provisions of this act, or who fails to eomply with any of the requirements of this act, shall be deemed guilty of a misdemeanor, and upon conviction thereof, shall, when no other penalty is preseribed, be fined not less than ten nor more than one hundred dollars for each offense. But this aet shall not be construed to apply to any one who manufactures fertilizers for his own use and not for sale.

14. The Director of said Experiment Station shall report to the proseeuting attorney of the county where the offense was committed all violations of the provisions of this act, and failure to comply therewith, and a copy of any label, statement or tag required to be filed with said Direetor or prepared by him, and any analysis made or eaused to be made by him, when duly eertified by said Director, shall be received in evidence in any prosecution ol suit for any violation of the provisions of this aet.

I, Harry Shaw, Clerk of the House of Delegates of West Virginia, hereby certify that the paper hereto annexed is a true eopy of an Aet of the Legislature of West Virginia passed on the second day of February, 1901, and approved by the Governor on the ninth day of February, 1901; and that the same takes a? ect ninety days from the date of its passage.

Given under my hand this Mareh 20th, 1901.

\section{Harry Shaw,} Clerk of the House of Delegates. 

